\title{
De los trasplantes legales a las traducciones legales: la globalización del plea bargaining y la tesis de la "americanización" en el proceso penal
}

\author{
From Legal Transplants to Legal Translations: \\ The Globalization of Plea Bargaining and the \\ Americanization Thesis in Criminal Procedure
}

Máximo Langer ${ }^{\star *}$

Recepción y evaluación de propuesta: $2 / 5 / 18$

Aceptación: 2/6/18

Recepción y aceptación final: 9/4/2019

\begin{abstract}
Resumen: el artículo analiza la implementación e influencia del sistema procesal norteamericano en otras jurisdicciones, con especial énfasis en el procedimiento penal y el denominado juicio abreviado. Se propone revisitar la idea de "transplante" legal y se sugiere explorar otras figuras, como la de la "traducción". Tal concepto ilumina mejor el modo en que los sistemas son usados, trasladados e incorporados en sistemas foráneos. En contra de la llamada "tesis de la americanización" se propone observar el modo real en que el "plea bairgaining" estadounidense ha sido adoptado en cuatro jurisdicciones diferentes.
\end{abstract}

Palabras clave: derecho comparado, plea bargaining, proceso abreviado, traducción

Traducción de Lucas Tassara.

* Catedrático de Derecho Penal, Derecho Procesal Penal y Derecho Penal Internacional de la Facultad de Derecho de la Universidad de California, Los Ángeles; Doctor en Ciencias Jurídicas, Universidad de Harvard; Abogado, Universidad de Buenos Aires.

Correo electrónico: langer@law.ucla.edu. 


\begin{abstract}
American legal system in foreign jurisdictions. The main argument focuses on the plea bargaining in Criminal Law Procedures and the so called "legal transplants". According to the article, the idea of "translation" fits better with the real phenomenon of legal ideas and institutions travelling abroad. Against the thesis of the americanization of other legal systems, the article analyses the development of the plea bargaining in four different jurisdictions.
\end{abstract}

Keywords: comparative law, plea bargaining, translation

\title{
1. Introducción
}

Desde el final de la Segunda Guerra Mundial, y en especial luego de la culminación de la Guerra Fría, el sistema legal estadounidense se ha posiblemente vuelto el más influyente en el mundo ${ }^{1}$. La influencia sobre los sistemas legales de otras naciones ha incluido desde una influencia general sobre la teoría general del derecho (v.g., realismo y pragmatismo jurídico, derecho y economía, discurso de los derechos, etc. $)^{2}$ hasta una influencia sobre distintas áreas específicas del derecho (v.g., derecho constitucional ${ }^{3}$,

1 Ver, por ejemplo, Kennedy D, “Three Legal Globalizations”, Inédito, 2001, inédito (archivos de Harvard International Law Journal); Mattei, U., "A Theory of Imperial Law: A Study on U.S. Hegemony and the Latin Resistance", Indiana Journal of Global Legal Studies, vol. 10, p. 383 (2003); Mattei, U., "Why the Wind Changed: Intellectual Leadership in Western Law" en American Journal of Comparative Law, vol. 42, p. 195 (1994); Wiegand, W., “Americanization of Law: Reception or Convergence?", en Friedman, L.M. y Scheiber H.N. (eds.) Legal Culture and The Legal Profession. Boulder, West View, 1996, p. 137; Wiegand, W., "The Reception of American Law in Europe", American Journal of Comparative Law, vol. 39, p. 229 (1991).

2 Ver, Kennedy, op.cit y Mattei, "Why the Wind Changed", op. cit.

3 Ver, por ejemplo, Henkin, L. y Rosenthal, A.J., Constitutionalism and Rights: The Influence of the United States Constitution Abroad. Columbia, Columbia University Press, 1990; Davison, J., "America's Impact on Constitutional Change in Eastern Europe", Albany Law Review, 55, 793 (1992). Para un trabajo que advierte sobre la adopción del modelo constitucional estadounidense por otros países, ver Zasloff, J., “The Tyranny of Madison”, UCLA Law Review, vol. 44, p. 795 (1997). 
De los trasplantes legales a las traducciones legales: la globalización del plea...

derecho tributario ${ }^{4}$, derecho bursátil ${ }^{5}$, derecho empresarial ${ }^{6}$, propiedad intelectual ${ }^{7}$, arbitraje comercial internacional ${ }^{8}$, etc.); desde la enseñanza del derecho (v.g., el sistema de créditos por determinados cursos, o ciertos estudios de post-grado que permiten obtener una maestría o LL.M.) ${ }^{9}$ y el modo en que se estructura la profesión legal (v.g., grandes estudios jurídicos ${ }^{10} \mathrm{o}$ la valorización de la práctica privada ${ }^{11}$ ) hasta la reforma del poder judicial ${ }^{12}$; desde doctrinas o herramientas jurídicas específicas (v.g., las reglas de exclusión constitucional de prueba ${ }^{13}$, la doctrina de la "actual

4 Stewart, M., "Global Trajectories of Tax Reform: The Discourse of Tax Reform in Developing and Transition Countries", en Harvard International Law Review, vol. 44, pp. 139, 151 (2003).

5 Ver, por ejemplo, Tung, F., "Passports, Private Choice, and Private Interests: Regulatory Competition and Cooperation in Corporate, Securities, and Bankruptcy Law", en Chicago Journal of International Law CHI. J. INT'L L., vol. 3, n.43, p. 369, (2002).

6 Von Nessen, P., "The Americanization of Australian Corporate Law", en Syracuse Journal of International Law and Commerce, vol. 26, p. 239 (1999).

7 Ver, por ejemplo, Alpert Gladstone, J., "Why Patenting Information Technology and Business Methods is Not Sound Policy: Lessons from History and Prophecies for the Future", Hamline Law Review, vol. 25, pp. 217, 229 (2002).

8 Delazay, Y. y Garth B.G., Dealing in Virtue: International Commercial Arbitration and the Construction of a Transnational Legal Order, Chicago, Chicago University Press, 1996.

9 Ver, por ejemplo, Wiegand, T., “Americanization", supra nota 1, pp. 138-39; Wiegand, T., “The Reception", supra nota 1, pp. 232-33.

${ }^{10}$ Ver, por ejemplo, Nota Estudiantil, "The Protectionist Bar against Foreign Lawyers in Japan, China and Korea: Domestic Control in the Face of Internationalization”, Columbia Journal of Asian Law, vol. 16, pp. 385, 389 (2003) ("La creciente presencia de estudios jurídicos en Japón ha estimulado aún más la "americanización" de la práctica legal, pero no sin continuas restricciones").

${ }^{11}$ Ver, por ejemplo, Ortwein II, B. M., "The Swedish Legal System: An Introduction" en Indiana International and Comparative Law Review, vol. 13, p. 405 (2003). (n.247: "El profesor Modeer sostiene que la 'americanización' de la profesión legal sueca ha producido un aumento en el número de graduados de las facultades de derecho que buscan afiliarse al Colegio de Abogados de Suecia con la esperanza de que ello les facilite una carrera como abogados privados").

${ }^{12}$ Ver, por ejemplo, Chodosh, Hiram E., "Reforming Judicial Reform Inspired by U.S. Models", DePaul Law Review, vol. 52, p. 351 (2002).

13 Argentina, Canadá, Italia y España, entre otros países, han adoptado una versión de la regla de exclusión estadounidense respecto a la prueba obtenida en violación de los derechos constitucionales. Sobre la experiencia canadiense, ver, por ejemplo, Stribopoulos, J., "Lessons from the Pupil: A Canadian Solution to the American Exclusionary Rule Debate", Boston College International and Comparative Law Review, vol. 22, p. 77 (1999). 
malicia" en el ámbito de la libertad de expresión y de prensa ${ }^{14}$, las acciones de clase o colectivas ${ }^{15}$, etc.) hasta disposiciones constitucionales como la separación de poderes y la revisión judicial ${ }^{16}$. Estas innegables influencias estadounidenses sobre otros sistemas legales han llevado a varios autores, tanto dentro como fuera de los Estados Unidos, a afirmar que un número importante de sistemas legales, tanto domésticos como internacionales, gradualmente podrían parecerse o imitar al sistema legal estadounidense y, por lo tanto, "americanizarse"17. Hay otros autores que, si bien reconocen la influencia predominante del sistema legal estadounidense, no sostienen que esa influencia esté efectivamente recreando la práctica jurídica estadounidense en otros sistemas legales ${ }^{18}$.

En este artículo prevengo contra la tesis de la "americanización" recién señalada (tesis "fuerte") a través de un análisis de la introducción del plea bargaining estadounidense en cuatro países de tradición continental europea y latinoamericana (Alemania, Italia, Argentina y Francia) ${ }^{19}$. La influen-

${ }^{14}$ Para un análisis sobre la recepción de esta doctrina en la Corte Suprema de Justicia de la Nación de Argentina, ver, por ejemplo, Bertoni, E.A., Libertad de expresión en el Estado de Derecho, Buenos Aires, Editores del Puerto, 2000, pp. 72-82.

15 Gidi, A., "Class Actions in Brazil--A Model for Civil Law Countries", en American Journal of Comparative Law vol. 51 (2003) (señala cómo las acciones de clase o colectivas anglo-americanas influyeron en los desarrollos brasileros mediante los trabajos de la doctrina italiana).

${ }^{16}$ Ver, por ejemplo, Blankenburg, E., "Changes in Political Regimes and Continuity of the Rule of Law in Germany", en Jacob, H., et al. Courts, Law and Politics in Comparative Perspective, Michigan, Yale University Press, 1996, pp. 249, 308 [de ahora en Adelante Courts, Law and Politics].

${ }^{17}$ Ver, por ejemplo, Keleman, R. D. y Sibbitt, Eric C., "The Americanization of Japanese Law", en University of Pennsylvania Journal of International Economic Law, vol. 23, p. 269 (2002); von Nessen, supra nota 6; Wiegand, T., “The Reception”, supra nota 1, pp. 246-48 (comparando la "americanización" de los sistemas legales europeos actuales con la recepción del ius commune en la Edad Media en aquél continente).

18 Ver, por ejemplo, Gidi, A., supra nota 15; Kennedy, D., supra nota 1; Zamora, S., “The Americanization of Mexican Law: Non-Trade Issues in the North American Free Trade Agreement", Law and Policy in International Bussiness, vol. 24, p. 391 (1993) (discutiendo las diferencias que existen entre las leyes laborales y ambientales de México y Estados Unidos, así como los respectivos mecanismos de aplicación, a pesar de las presiones sobre el sistema legal mexicano de imitar al estadounidense).

${ }^{19}$ Elegí estas cuatro jurisdicciones por dos motivos. Primero, tradicionalmente han sido consideradas como influyentes en otros países (Francia, Alemania e Italia en todo el mundo, y Argentina en América Latina). Por ende, y en la medida en que siguen manteniendo parte 
De los trasplantes legales a las traducciones legales: la globalización del plea...

cia del plea bargaining estadounidense en estas cuatro jurisdicciones es innegable. Sin embargo, y a pesar de ello, es improbable que la importación del plea bargaining en estas cuatro jurisdicciones reproduzca el modelo estadounidense de proceso penal. Cada una de estas jurisdicciones ha adoptado una forma de plea bargaining que contiene diferencias - incluso sustanciales- con el modelo estadounidense, sea por decisiones tomadas por los impulsores o los encargados de las reformas en cada jurisdicción, o por diferencias estructurales entre el proceso penal estadounidense y los procesos penales de la tradición continental europea y latinoamericana. En consecuencia, algunas versiones del plea bargaining difieren desde su concepción con la práctica estadounidense. Además, las diferencias estructurales entre la concepción acusatoria estadounidense y la concepción inquisitiva continental europea y latinoamericana del proceso penal son tan profundas que es poco probable que reformas individuales inspiradas en modelos estadounidenses empujen esos procesos penales inquisitivos sustancialmente en la dirección del sistema acusatorio estadounidense. Por último, en cada una de estas jurisdicciones continentales europeas y latinoamericanas algunos actores han desconfiado o resistido la adopción del plea bargaining y otros mecanismos consensuales, sea porque las reformas significaban una amenaza a su poder tradicional en el proceso penal inquisitivo o por su distinta cultura jurídica. Esta desconfianza y resistencia también han sido importantes para neutralizar el potencial de "americanización” inherente en algunas de estas reformas procesales penales.

Aunque los factores que obstaculizan su "americanización" han estado presentes en cada una de las jurisdicciones examinadas, han tenido un papel diferente en cada una de ellas. No sólo estas jurisdicciones adoptaron una versión del plea bargaining diferente del modelo estadounidense, sino que también cada una de ellas ha adoptado formas de plea bargaining distintas entre sí. Los plea bargaining alemán, italiano, argentino y francés difieren sustancialmente entre sí por decisión de los impulsores y los encargados de

de su ascendencia sobre otros países de la misma tradición jurídica constituyen un buen indicador de lo que puede ocurrir en buena parte de ese mundo jurídico. Segundo, cada una de estas jurisdicciones brinda una versión distinta del modo en que el plea bargaining puede ser importado por los países de esa tradición jurídica y los diferentes efectos que estas versiones pueden producir en cada uno de ellos. 
las reformas legales en cada uno de esos países, por las distintas formas en que la práctica ha sido introducida y por la resistencia generada. Dadas las diferencias que presentan estos mecanismos, la adopción de alguna forma de plea bargaining en estas jurisdicciones podría producir diferentes transformaciones o efectos en cada jurisdicción. Por lo tanto, el efecto potencial del plea bargaining estadounidense sobre las jurisdicciones continentales europeas y latinoamericanas no sería tanto que estos sistemas comiencen a parecerse gradualmente al sistema legal estadounidense, sino que comiencen a diferenciarse entre ellos en aspectos en los cuales, hasta hace muy poco, eran relativamente homogéneos. En otras palabras, el efecto paradójico de la influencia estadounidense sobre los procesos penales de la tradición continental europea y latinoamericana no sería el de la "americanización", sino el de la fragmentación y divergencia entre aquellos sistemas.

Antes de comenzar con el análisis concreto de estas importaciones es necesario abordar dos cuestiones. Primero, a fin de explicar y trazar las transformaciones que el plea bargaining estadounidense ha sufrido desde que fue adoptado por primera vez por estas jurisdicciones continentales europeas y latinoamericanas, hay que explicar las diferencias históricas entre el proceso penal acusatorio estadounidense y los procesos penales inquisitivos de la tradición continental europea y latinoamericana. Los sistemas acusatorio e inquisitivo pueden ser entendidos no sólo como dos formas distintas de distribuir el poder y las responsabilidades entre varios actores legales —órgano decisor (juez y/o jurado), fiscalía y defensa- sino también como dos culturas procesales diferentes y, por ende, dos tipos distintos de entendimientos básicos sobre el modo en que los casos penales deben ser enjuiciados y perseguidos ${ }^{20}$. La mayor diferencia entre estas

${ }^{20}$ En este sentido es importante señalar desde el principio que utilizaré la expresión "sistema acusatorio" como una categoría descriptiva, no como un ideal normativo. Como ideal normativo la expresión a veces es utilizada en Estados Unidos para referirse a un proceso penal en donde los derechos del acusado son plenamente respetados, ver, por ejemplo, Damaška, M., "Adversary System", en Kadish, S.H. (ed.), Encyclopedia of Crime and Justice, Nueva York, Free Press, 1983, vol. 1, pp. 24, 25 y la epítome del sistema acusatorio es el juicio por jurados. Sin embargo, en este artículo utilizaré la expresión "sistema acusatorio" como una categoría descriptiva a través de la cual voy a explicar las características actuales del proceso penal estadounidense por oposición a las actuales características del proceso penal en Europa continental y en América Latina. Del mismo modo, la expresión "sistema 
De los trasplantes legales a las traducciones legales: la globalización del plea...

culturas procesales a los fines de este artículo es que mientras el sistema acusatorio concibe al proceso penal como la regulación de una disputa entre dos partes (fiscalía y defensa) ante un órgano decisor pasivo (juez y/o jurado), el sistema inquisitivo concibe al proceso penal como una investigación oficial única llevada a cabo por uno o más oficiales imparciales del Estado a fin de averiguar la verdad ${ }^{21}$.

Dado que estas diferencias culturales han sido pasadas por alto por la doctrina y estudios tradicionales del derecho procesal comparado, en este artículo propongo un nuevo marco teórico para reconceptualizar los sistemas acusatorio e inquisitivo. Este nuevo marco teórico será útil no sólo para describir las diferencias entre los procesos penales del common law y de la tradición continental europea y latinoamericana, sino también para analizar algunas de las transformaciones que el plea bargaining - $y$ potencialmente otras instituciones jurídicas - pueden sufrir cuando son transferidas de un sistema a otro. Este marco teórico también será de utilidad para evaluar la "americanización" producida por la adopción de alguna forma de plea bargaining en estos cuatro sistemas procesales penales continentales europeos y latinoamericanos, puesto que proveerá un eje claro de referencia para comparar las diferencias entre los sistemas acusatorios e inquisitivos y, por ende, para evaluar si los últimos se están moviendo en dirección a los primeros.

Segundo, es necesario cuestionar y reevaluar cómo pensamos sobre la circulación de las ideas legales entre sistemas jurídicos. La metáfora del "trasplante legal" ha sido la principal herramienta utilizada por la doctrina y los practicantes del derecho comparado, para analizar la importación de prácticas legales foráneas ${ }^{22}$. Sin embargo, esta metáfora tiene sus defectos.

inquisitivo" muchas veces es usada en forma negativa para referirse a concepciones autoritarias del proceso penal. Pero en este artículo también voy a utilizar la expresión "sistema inquisitivo" sólo como una categoría descriptiva.

${ }^{21}$ Como lo explico más adelante, no considero que los sistemas acusatorio e inquisitivo sean culturas procesales homogéneas. Pero estas dos concepciones han sido predominantes en las cinco jurisdicciones que examino en este artículo y por lo tanto son las más relevantes para nuestro estudio.

22 Ver generalmente Berkowitz, D., et al. "Economic Development, Legality, and the Transplant Effect" (Center for International Development at Harvard University, Working Paper No. 39, 2000, disponible en http:// www.cid.harvard.edu/cidwp/039.htm (último acceso el 
Su principal problema es que asume o encierra la noción de que las ideas e instituciones legales se pueden "cortar y pegar" de un sistema a otro. Por lo tanto, esta metáfora no logra transmitir las transformaciones que pueden sufrir las ideas e instituciones legales cuando son transferidas entre sistemas jurídicos. En este artículo propongo la metáfora de la "traducción legal" como una herramienta heurística alternativa para analizar la transferencia de las ideas e instituciones legales entre distintos sistemas. Los sistemas acusatorio e inquisitivo, considerados como dos culturas procesales distintas, pueden ser entendidos como dos sistemas de producción de sentido diferentes. Así, la transferencia de instituciones legales de un sistema a otro puede ser entendida como traducciones de un sistema de sentido al otro. Específicamente, se puede considerar que las transformaciones que ha sufrido el plea bargaining al ser transferido a estas jurisdicciones continentales europeas y latinoamericanas son, o bien decisiones tomadas por los "traductores" (i.e., los impulsores y encargados de la reforma), o bien producto de diferencias estructurales que existen entre los "lenguajes" acusatorio e inquisitivo.

En este trabajo mostraré que la influencia del proceso penal estadounidense parece confirmar la versión débil de la tesis de la "americanización", y que la versión fuerte de esa tesis es inaplicable o, al menos, demasiado simplista con relación al proceso penal. A pesar de la influencia del plea

25 de noviembre de 2003) (en los archivos de Harvard International Law Journal); Buscaglia, E. y Rafliff, W., Law and Economics in Developing Countries, Hoover Institution Press, 2000, pp. 14-19, 31-54; Watson, A., Legal Transplants: an Approach to Comparative Law, Londres y Atenas, Georgia University Press, 2a ed., 1993, p. 21; Ajani, G., "By Chance and Prestige: Legal Transplants in Russia and Eastern Europe", en American Journal of Comparative Law vol. 43, p. 93 (1995); Mattei, U., "Efficiency in Legal Transplants: An Essay in Comparative Law and Economics", International Review of Law and Economics, vol. 14, p. 3 (1994); Miller, J.M., "A Typology of Legal Transplants: Using Sociology, Legal History and the Argentine Example to Explain the Transplant Process", en American Journal of Comparative Law vol. 51, 4 (2003); Mistelis, L. A., "Regulatory Aspects: Globalization, Harmonization, Legal Transplants and Law Reform--Some Fundamental Observations", en International Law, vol. 34 (2000), p. 1055; Schauer, F., “The Politics and Incentives of Legal Transplantation”, en Nye, Joseph S. Jr. \& Donahue, John D. (eds.), Governance in a Globalizing World, Washington, Brookings Institution Press, 2000 (p. 253.); Weiner, J. B., "Responding to the Global Warming Problem: Something Borrowed for Something Blue: Legal Transplants and the Evolution of Global Environmental Law", Ecology Law Quaterly, vol. 27, p. 1295 (2001). 
De los trasplantes legales a las traducciones legales: la globalización del plea...

bargaining en las jurisdicciones continentales europeas y latinoamericanas, las diferencias culturales entre los sistemas acusatorios e inquisitivos son demasiado profundas como para ser superadas por una única reforma de inspiración estadounidense, o inclusive por un número sustancial de reformas con la misma inspiración. Además, y teniendo en cuenta que cada una de estas jurisdicciones continentales europeas y latinoamericanas ha traducido el plea bargaining en forma diferente, el efecto final de esta influencia estadounidense dentro del proceso penal continental europeo y latinoamericano, será el de la fragmentación y divergencia, más que la “americanización”. Las cuatro jurisdicciones examinadas en este artículo comparten una cultura procesal penal similar que considera al proceso penal como una investigación oficial llevada a cabo por funcionarios imparciales. Sin embargo, cada jurisdicción ha adoptado una versión distinta del plea bargaining y, por ello, estas diferentes reformas los pueden conducir en direcciones diferentes.

La estructura de este artículo es la siguiente: en las secciones II y III propongo un nuevo marco teórico para conceptualizar los sistemas acusatorio e inquisitivo. La principal idea que defiendo aquí es que estas categorías deben ser entendidas no sólo como dos formas distintas de distribuir el poder y las responsabilidades entre los principales actores del proceso penal (jueces, fiscales, abogados defensores, etc.), sino también como dos culturas procesales diferentes. En la sección IV muestro las influencias que ha tenido la concepción anglo-americana del proceso penal en el proceso penal inquisitivo de la Europa continental y Latinoamérica en las últimas décadas. En la sección V se discuten los problemas que presenta la metáfora del "trasplante legal" como una herramienta heurística para analizar la circulación de las instituciones legales entre sistemas legales. Aquí ofrezco la metáfora de la "traducción legal" como una herramienta heurística más productiva y refinada para pensar estos problemas. La práctica legal transferida - en este caso el plea bargaining - puede ser pensada como el "texto" que ha sido traducido de un "idioma" - el sistema acusatorio de los Estados Unidos - hacia otro "idioma" - los sistemas inquisitivos de Alemania, Italia, Argentina y Francia - . La sección VI explica cómo el plea bargaining puede tener un efecto de "americanización" potencial en las jurisdicciones continentales europeas y latinoamericanas, si fuese completamente aceptado por 
estos sistemas. Sobre esta cuestión considero que el plea bargaining estadounidense asume una concepción acusatoria del proceso penal y, por ende, si fuese traducido fielmente y aceptado completamente por las jurisdicciones continentales europeas y latinoamericanas podría promover la concepción estadounidense del proceso penal en esas jurisdicciones. Las secciones VII, VIII, IX y X analizan los “plea bargains” alemán, italiano, argentino y francés, y explican no sólo por qué cada uno de estos países ha traducido el plea bargaining estadounidense, sino también por qué cada uno de ellos ha escogido traducir esa práctica de forma distinta. Aquí demuestro además, cómo la concepción cultural inquisitiva del proceso penal ha sido uno de los principales motivos por los cuales el plea bargaining estadounidense ha sido transformado y resistido en estas jurisdicciones. Por último, la sección XI articula mi argumento central: dado que cada una de las jurisdicciones examinadas ha traducido el plea bargaining en forma distinta, las influencias estadounidenses pueden terminar produciendo la fragmentación y divergencia, más que la "americanización" del derecho procesal penal de la tradición continental europea y latinoamericana.

\section{Reconceptualización de lo acusatorio y lo inquisitivo como categorías teóricas}

La doctrina y estudios del derecho comparado y del derecho procesal penal comparado tradicionalmente han utilizado las categorías teóricas "acusatorio" e "inquisitivo" de dos modos principales ${ }^{23}$ : el del mínimo denominador

${ }^{23}$ El uso de las expresiones "acusatorio" e "inquisitivo" no se ha limitado al proceso penal comparado. Para las descripciones de otros usos de estos términos, ver Damaška, M., "Adversary System”, op. cit. en p. 24 Feeley, M., “The Adversary System", en Janosik, R.J. (ed.) Encyclopedia of the American Judicial, Charles Scribners Sons, 1987 p. 753; Langer, M., "La Dicotomía acusatorio-inquisitivo y la importación de mecanismos procesales de la tradición jurídica anglosajona. Algunas reflexiones a partir del procedimiento abreviado", en. Maier, Julio B. J \& Bovino, A. (eds.) El procedimiento abreviado. Buenos Aires, Editores del Puerto, 2001. pp. 97, 102-11. Se pueden consultar estudios sobre otros modelos y categorías que se han utilizado para analizar los diferentes tipos de procesos penales, por ejemplo, en Packer, H.L., The Limits of the Criminal Sanction. Stanford, Stanford University Press, 1968, pp. 149-246; Arenella, P., "Rethinking the Functions of Criminal Procedure: The Warren and Burger Courts' Competing Ideologies", Georgetown Law Journal, vol. 72, 
De los trasplantes legales a las traducciones legales: la globalización del plea...

común y el del tipo ideal ${ }^{24}$. Según el criterio del mínimo denominador común, las categorías acusatorio e inquisitivo simplemente contienen las características comunes a todos los sistemas procesales penales del common law y de las jurisdicciones continentales europeas, latinoamericanas y similares (civil law) respectivamente ${ }^{25}$. Por ejemplo, el juicio por jurados o la regla sobre el testimonio "de oídas" serían características del sistema acusatorio si todas las jurisdicciones del common law incluyeran estos elementos en un momento dado. Este criterio presenta varios problemas. Primero, cada vez que una jurisdicción particular abandona una característica que era parte de este mínimo denominador común los seguidores de este criterio tendrían el siguiente dilema: o bien deberían modificar el contenido de los sistemas acusatorio e inquisitivo, o bien deberían remover a estas jurisdicciones del sistema acusatorio o inquisitivo. El criterio del mínimo denominador común no brinda una respuesta clara para lidiar con este dilema ${ }^{26}$. Segundo, tampoco queda claro cómo distinguir las características principales de las secundarias en ambos sistemas. En otras palabras, el criterio del mínimo denominador común no dice por qué ciertas características son más relevantes que otras para distinguir los dos sistemas ${ }^{27}$. Tercero, este criterio no parece útil para analizar los sistemas híbridos que han sido influenciados por ambas tradiciones legales, y quizás también por otras tradiciones legales del mundo. Estos sistemas mixtos constituyen un fenómeno muy importante para estudiar actual-

p. 183 (1983); Damaška, M., "Models of criminal procedure”, Zbornik PFZ, 51, (2001); Griffiths, J., "Ideology in Criminal Procedure, or a Third 'Model' of the Criminal Process", Yale Law Journal, vol. 79, p. 359 (1970); Luna, E. G., "The Models of Criminal Procedure”, Buffalo Criminal Law Review, vol. 2, p. 389 (1999).

${ }^{24}$ Ver en general Damaška, M. R., The Faces of Justice and State Authority: a Comparative Approach to the Legal Process, Yale University Press, 1986.

25 Ver Damaška, M., "Adversary System", op. cit, .p. 28 (poniendo como un ejemplo de esta perspectiva, Herrmann, J., "Various Models of Criminal Proceedings", South African Journal of Criminal Law and Criminology, vol. 2, pp. 3, 4-6,1978). Para rechazar la idea de que la regla de exclusión de la prueba obtenida ilegalmente no es una característica definitoria del sistema acusatorio, el profesor Herrmann señala que la regla de exclusión no ha sido adoptada por todas las jurisdicciones anglo-americanas, y que ha sido adoptada en la legislación de varios países europeos. Ibid. p. 18.

${ }^{26}$ Ver Damaška, M., op.cit, supra nota 24, p. 5.

${ }^{27}$ Idem. 
mente, no sólo porque la incidencia de los sistemas nacionales híbridos es mayor ahora que en el pasado debido a las influencias mutuas entre el common law y el civil law, sino también para entender a los tribunales penales internacionales, de Núremberg a la Corte Penal Internacional, en donde se mezclan e interactúan normas y profesionales del derecho de diferentes tradiciones legales ${ }^{28}$. Finalmente, este criterio no parece ofrecer un marco teórico adecuado para explicar el fenómeno de las influencias legales y los trasplantes legales puesto que lo máximo que puede ofrecer, cuando una práctica legal (como el plea bargaining) es transferida de una jurisdicción acusatoria a una inquisitiva, es que, o bien la ausencia de esta institución ya no es más una característica definitoria del sistema inquisitivo, o bien que la específica jurisdicción receptora no forma más parte de la familia legal inquisitiva, con lo cual nos reconduce al primer problema del criterio del mínimo denominador común.

El segundo criterio generalmente utilizado por el derecho procesal penal comparado consiste en la conceptualización de lo acusatorio y lo inquisitivo como tipos ideales weberianos ${ }^{29}$. Estos modelos no existen

${ }^{28}$ Para diversos análisis del procedimiento y las reglas probatorias de diferentes jurisdicciones penales internacionales con base en la dicotomía entre lo acusatorio y lo inquisitivo, ver, por ejemplo, Champy, G., "Inquisitoire-Accusatoire devant les juridictions pénales internationales", en International Law Review of Penal Law, vol. 68, 1997, p. 149; Combs, N. A., "Copping a plea to genocide: the plea bargaining of international crimes", University of Pennsylvania Law Review, 151, 2002; May, R. y Wierda, M., “Trends in International Criminal Evidence: Nuremberg, Tokyo, The Hague, and Arusha”, Columbia Journal of Transnational Law, vol. 37, 1999, p. 725; Mundis, D. A., "From 'Common Law' Towards 'Civil Law': The Evolution of the ICTY Rules of Procedure and Evidence”, Leiden Journal of International Law, vol. 14, 2001, p. 367; Tochilovsky, V., "Rules of Procedure for the International Criminal Court: Problems to Address in Light of the Experience of the Ad Hoc Tribunals", Netherland International Law Review, vol. 46, 1999, p. 343.

${ }^{29}$ En su clásica descripción de la metodología de Weber, Max Rheinstein escribe: "Nunca han existido en la historia situaciones como las descriptas en los tipos "puros". Estos tipos son construcciones artificiales similares a las construcciones puras de la geometría. Ningún triángulo, cubo o esfera puro han existido alguna vez. Pero la realidad nunca ha sido penetrada científicamente sin el uso de los conceptos artificiales de la geometría. Para los conceptos "puros" que creó, Weber utilizó el término "tipo ideal" ... Los "tipos ideales"... son simplemente construcciones mentales cuyo propósito es servir como categorías de pensamiento cuyo uso nos ayudará a captar la infinita multiplicidad de la realidad al comparar este fenómeno con los tipos "ideales" que se utilizan, por así decirlo, para que sirvan 
De los trasplantes legales a las traducciones legales: la globalización del plea...

realmente en ningún sistema legal histórico pero, mientras que las jurisdicciones del common law serían más cercanas al tipo acusatorio, las jurisdicciones continentales europeas y latinoamericanas serían más cercanas al tipo inquisitivo ${ }^{30}$.

Esta concepción teórica es mucho más promisoria que la del mínimo denominador común y no presenta muchos de sus defectos. Por ejemplo, el uso de los tipos ideales identifica las diferencias relevantes entre los sistemas acusatorios e inquisitivos, y una modificación en un sistema procesal penal concreto no implica necesariamente cambiar o descartar el modelo. Por el contrario, este criterio sólo se limita a catalogar a los procesos penales concretos como más cercanos o más lejanos del tipo ideal. Además, el criterio del tipo ideal es de utilidad para analizar los procesos penales híbridos como el de los tribunales penales internacionales puesto que identifica aquellas características que se corresponden con cada tipo ${ }^{31}$. El criterio del tipo ideal también brinda un marco adecuado para analizar el fenómeno de las influencias y el trasplante legal entre los procesos del common law y de las jurisdicciones continentales europeas y latinoamericanas ${ }^{32}$. Primero, al suministrar un marco de referencia claro este criterio nos permite analizar hasta qué punto los procesos penales son transformados como consecuencia de las influencias o el trasplante. Segundo, en la medida en que los procesos penales concretos son más cercanos a los tipos ideales, estos tipos explican los incentivos y la lógica del sistema, de modo tal que es posible identificar de antemano posibles focos de resistencia a una reforma.

\subsection{Estructuras de interpretación y sentido}

como guías en un sistema de archivo". Rheinstein, M., "Introduction", en Rheinstein (ed.) Max Weber on Law in Economy and Society, Harvard University Press, 1954.

${ }^{30}$ Mirjan Damaška ha mostrado el uso más sofisticado de esta interpretación, aunque él reemplaza a lo acusatorio y lo inquisitivo con sus propias categorías. Ver Damaška, M., The Faces of Justice...op. cit.

${ }^{31}$ Ver, por ejemplo, Tochilovsky, V., op. cit., supra nota 28.

32 Ver Damaška, M., "The Uncertain Fate of Evidentiary Transplants: Anglo-American and Continental Experiences", American Journal of Comparative Law vol. 45, 1997, p. 839; Grande, E., "Italian Criminal Justice: Borrowing and Resistance", American Journal of Comparative Law vol. 48, 2000, p. 227. 
No obstante lo expuesto, hay un área que la perspectiva del tipo ideal no aborda, o bien relega, y que quisiera poner de resalto en este artículo. Los modelos acusatorios e inquisitivos no son sólo dos formas de estructurar los procedimientos penales, sino también dos formas de entender y representar el proceso penal. Por ejemplo, los jueces del common law intervienen mucho menos que sus colegas continentales en el interrogatorio de los testigos, no sólo porque las reglas procesales les otorgan menos potestades para hacerlo, sino también porque el rol del juez es entendido en forma diferente en el sistema anglosajón o del common law. Mientras que el juez del sistema inquisitivo es entendido y percibido como un investigador activo y, consecuentemente, con el deber de ser activo en estos interrogatorios, el juez del sistema acusatorio es generalmente entendido como un árbitro pasivo que supuestamente no debe intervenir activamente en el interrogatorio de los testigos ${ }^{33}$.

${ }^{33}$ Con la reconceptualización de los sistemas acusatorio e inquisitivo desarrollada en este artículo, intento captar el punto de vista interno de los actores legales que son parte de los procesos penales anglosajones o del common law y de las jurisdicciones continentales europeas y latinoamericanas. Esta distinción entre un punto de vista externo e interno ha sido utilizada en una multiplicidad de disciplinas. Por ejemplo, Max Weber tomó en cuenta esta distinción al incluir como objeto de estudio sociológico no sólo al aspecto externo del comportamiento humano, sino también al sentido que los seres humanos les otorgan a su propio comportamiento. Ver Rheinstein, M., op. cit., p. XXIX-XXX: "La observación de que una persona le entrega a otra un pedazo de papel verdoso es, como tal, irrelevante en el estudio de las relaciones humanas. Este fenómeno no asume significancia social hasta que sabemos que un gran número de personas, de las cuales nuestros dos actores son miembros, consideran a este papel verdoso como un billete de papel moneda o, en otras palabras, que le asignan la función de servir como un medio de intercambio y pago generalmente reconocido." Idem p. XX. En la teoría del derecho, la referencia clásica es H. L. A. Hart, quien utilizó esta distinción entre el punto de vista externo y el interno. Hart, H.L.A., The Concept of Law, Oxford, Oxford University Press, 2a ed., pp. 88-91. Ver también Kahn, P. W., The cultural study of law: Reconstructing legal scholarship, University of Chicago Press, 2000. En los estudios de antrolopogía Clifford Geertz ha intentado captar la idea del punto de vista interno a través de su concepto de la "descripción densa". Geertz, C., The interpretation of cultures, Vol. 5019. Basic books, 1973, pp. 5-10. Como Weber utilizó coherentemente el criterio del tipo ideal y tomó en cuenta el punto de vista interno de los actores sociales, no considero que mi reconceptualización de los sistemas acusatorio e inquisitivo sea incompatible con la perspectiva del tipo ideal; por el contrario, considero que simplemente son independientes uno del otro. Mi argumento es que el derecho procesal penal comparado generalmente ha pasado por alto el punto de vista 
De los trasplantes legales a las traducciones legales: la globalización del plea...

En otras palabras, lo acusatorio y lo inquisitivo pueden ser entendidos como dos diferentes estructuras de interpretación y sentido a través de las cuales los actores de un determinado sistema de justicia penal entienden tanto al proceso penal como al rol que ellos desempeñan en el sistema ${ }^{34}$. Dentro de estas dos estructuras procesales de interpretación y sentido, o "idiomas procesales", los mismos términos, o significantes, frecuentemente tienen sentidos distintos. Por ejemplo, en el sistema acusatorio la palabra "fiscal" significa una de las partes en disputa con un interés en el resultado del proceso; en el sistema inquisitivo, sin embargo, esta palabra hace referencia a un magistrado imparcial del Estado cuyo rol es investigar la verdad $^{35}$. La palabra "verdad" también tiene un significado diferente en cada estructura procesal de interpretación y sentido. En el sistema acusatorio, la disputa es sobre la "verdad" en tanto la fiscalía intenta probar que determinados eventos ocurrieron y que el imputado participó en ellos, mientras que la defensa intenta cuestionarlo o refutarlo. Pero el concepto de verdad acusatorio es más relativo y consensual: si las partes llegan a un consenso sobre los hechos del caso, mediante acuerdos sobre declaraciones de culpabilidad o estipulaciones, no es tan importante determinar cómo

interno de los actores del sistema de justicia penal, y que es fundamental la inclusión de esta perspectiva para examinar las diferencias entre los procesos penales del common law y las jurisdicciones continentales europeas y latinoamericanas, así como también para captar fenómenos como la circulación de ideas e instituciones legales entre ellos y los debates sobre la "americanización" del derecho.

34 Adopto la expresión "estructuras de sentido" de Geertz, C., "Local knowledge: fact and law in comparative perspective" en Geertz, C. Local knowledge: further essays in interpretive anthropology, New York, 1983, pp. 167, 182, quien señala: "El giro de la antropología... hacia una mayor preocupación por las estructuras de sentido en términos de las cuales individuos y grupos de individuos viven sus vidas, y más específicamente por los símbolos y sistemas de símbolos a través de cuya agencia tales estructuras son formadas, comunicadas, impuestas, compartidas, alteradas y reproducidas, ofrece tantas promesas para el análisis comparado del derecho como lo hace para los mitos, rituales, ideología, arte o la clasificación de sistemas, que constituyen los campos más probados de su aplicación”. Idem.).

35 Sobre las diferentes concepciones del fiscal en el sistema anglosajón y en el inquisitivo, ver, por ejemplo, Pizzi, W. T., "Understanding Prosecutorial Discretion in the United States: The Limits of Comparative Criminal Procedure as an Instrument of Reform", en Ohio, Ohio State Law Journal, vol. 54, 1993, pp. 1325, 1349-51; Weigend, T., "Prosecution: Comparative Aspects”, en Dressler, J. (ed.) Encyclopedia of Crime \& Justice 1235 (2001)., McMillan, 2002, pp. 1232, 1233-34. 
ocurrieron los hechos realmente ${ }^{36}$. En la estructura inquisitiva de interpretación y sentido, la "verdad" es concebida en términos más absolutos: se supone que el funcionario estatal - generalmente el juez - debe determinar, a través de la investigación, qué ocurrió en realidad, independientemente de los acuerdos o desacuerdos que la fiscalía y la defensa puedan llegar a tener sobre los hechos ${ }^{37}$.

Al mismo tiempo, hay ciertas ideas y conceptos que existen en un idioma procesal y no en el otro. Por ejemplo, el sistema acusatorio incluye tanto el concepto de la "confesión" - i.e., la admisión de culpabilidad ante la policíacomo el de "guilty plea" - y la admisión de culpabilidad frente al tribunal que, si es aceptada, tiene como consecuencia que pone fin a la fase de determinación de culpabilidad o inocencia. La estructura de interpretación y sentido o "idioma" procesal inquisitivo, por el contrario, no incluye el concepto del "guilty plea" o declaración de culpabilidad, sólo contiene el concepto de "confesión" ${ }^{8}$. En este sistema un acusado no puede poner fin a la etapa de la determinación de culpabilidad al admitir su responsabilidad ante el tribunal. Si bien la admisión de culpabilidad puede ser de mucha utilidad para el juez en la búsqueda de la verdad, lo cierto es que el juez todavía tiene la última palabra al respecto y en consecuencia puede decir: "le creo pero su confesión sola no es prueba suficiente más allá de toda duda razonable de que usted lo hizo". En todo caso, si la admisión de culpabilidad ocurre durante la etapa preparatoria del juicio, el caso todavía tiene que avanzar hasta el juicio para

${ }^{36}$ Esto puede parecer una exageración porque en las jurisdicciones estadounidenses el juez todavía tiene que verificar la base fáctica para una declaración de culpabilidad (guilty plea). Pero en la práctica, los jueces estadounidenses generalmente conceden deferencia hacia los acuerdos de las partes sobre los hechos. Además, casos como North Carolina v. Alford, 400 U.S. 25 (1970), en donde el acusado se declaró culpable, al tiempo que sostenía que en realidad era inocente, son claros ejemplos de una concepción de la verdad que es mucho más relativa y consensuada.

37 Sobre la concepción de la verdad predominante en el sistema inquisitivo, por oposición al acusatorio, ver Garapon, A., "French Legal Culture and the Shock of 'Globalization", Sociological and Legal Studies, vol. 4, 1995, pp. 493, 496-97

${ }^{38}$ Ver, por ejemplo, Moskovitz, M., "Perspective: The O.J. Inquisition: A United States Encounter with Continental Criminal Justice", Vanderbilt Journal of Transnational Law, vol. 28, 1995, pp. 1121, 1153. Este artículo describe las diferencias entre los sistemas acusatorio e inquisitivo haciendo una dramatización de cómo un caso similar al juicio de O. J. Simpson sería tratado por un sistema de justicia penal continental europeo o latinoamericano. 
De los trasplantes legales a las traducciones legales: la globalización del plea...

que el juez pueda tomar una decisión final ${ }^{39}$.

Es importante enfatizar que aun cuando es posible analizar las estructuras acusatorias e inquisitivas de interpretación y sentido como sistemas abstractos, estas estructuras sólo existen dentro de procesos penales concretos. Es decir, es posible identificar sistemas acusatorios e inquisitivos porque los actores legales de las jurisdicciones anglosajonas y las continentales europeas y latinoamericanas constantemente hacen uso de estructuras de interpretación y sentido acusatorias e inquisitivas, tanto de manera consciente como inconsciente. Tomando una distinción de la lingüística estructuralista, podría decir que mientras las estructuras de interpretación y sentido son la langue -el sistema abstracto de diferencias que establece un léxico y un conjunto de operaciones potenciales - , las prácticas son la parole - los actos de discurso concretos que son hechos posibles por la langue $e^{40}$.

\subsubsection{Disposiciones individuales}

Así como las estructuras de interpretación y sentido acusatorias e inquisitivas se basan en prácticas procesales concretas, también son internalizadas por los actores legales relevantes. A esto llamo la "dimensión de las disposiciones individuales" 41 . Estas disposiciones internas son adquiridas a través de la internalización de estructuras procesales de interpretación y sentido mediante un número de procesos de socialización (i.e., facultades

39 Ver, por ejemplo, Langbein, J. H., Comparative criminal procedure: Germany, St. Paul, MN.: West Publishing Company, 1977.

${ }^{40}$ Ver De Saussure, F., Course in general linguistics, New York, Philosophical Library, 1959.

${ }^{41}$ Mi fuente de inspiración para el desarrollo de esta dimensión de las disposiciones internas es el concepto del habitus del sociólogo Pierre Bourdieu, que puede ser definido como "un conjunto de disposiciones que inducen a los agentes a actuar y reaccionar de determinadas maneras. Las disposiciones generan prácticas, percepciones y actitudes que son 'regulares' sin ser concientemente coordinadas o regidas por ninguna 'regla". Véase la introducción de John B. Thompson a (y en) Bourdieu, P., Language and symbolic power, Harvard University Press, 1991. Pierre Bourdieu también describe su noción del habitus en otros trabajos. Bourdieu, P., Raisons pratiques. Sur la théorie de laction, Le seuil, 2016, pp. 22-23; Bourdieu, P., Sociology in question, Sage, Vol. 18, 1993, p. 72. Digo que la dimensión de las disposiciones internas solamente está inspirada en el concepto de Bourdieu porque no sigo su marco teórico en este artículo. Por lo tanto, mi uso de este concepto es idiosincrático. 
de derecho, escuelas judiciales, capacitación y entrenamiento en las oficinas de la fiscalía y estudios jurídicos, interacción con los tribunales, etc. ${ }^{42}$ ). Como resultado de esta socialización un importante número de actores del sistema de justicia penal está predispuesto a entender el proceso penal, y los diversos roles que en él se desarrollan, en una forma particular, y estas disposiciones se convierten en duraderas con el tiempo.

Por lo tanto, la idea del sistema acusatorio según la cual el juez debe ser un árbitro pasivo no es consecuencia únicamente de la estructura acusatoria de interpretación y sentido, sino también del fenómeno por el cual un número importante de actores legales han internalizado esta estructura de sentido en una jurisdicción del common law, y han llegado a considerar que se trata del rol propio de un juez y, generalmente, actúan en consecuencia - por ejemplo, cuestionando a un juez que participa muy activamente en el interrogatorio de los testigos $-{ }^{43}$. En otras palabras, en la medida en que los actores legales internalizan estas estructuras de sentido y luego interpretan e interactúan con la realidad a través de ellas, se podría decir que estas estructuras de sentido constituyen y forman a los actores legales como sujetos ${ }^{44}$.

La dimensión que tienen las disposiciones individuales resulta particularmente importante al estudiar la transferencia de ideas, normas e instituciones legales entre los sistemas acusatorio e inquisitivo, así como los trasplantes legales en general. Tal como lo veremos, una buena parte de la doctrina y estudios de los trasplantes legales discute la transferencia de las ideas legales del common law a las jurisdicciones continentales europeas y latinoamericanas, o viceversa, exclusivamente como interacciones, $o$

${ }^{42}$ Para una descripción de cómo son entrenados y socializados los abogados, jueces, fiscales y profesores en los países de la tradición continental europea y latinoamericana, ver, por ejemplo, Merryman, J. H., "The Civil Law Tradition: An Introduction to the Legal Systems of" (1985), pp. 101-10 (2a ed. 1985).

43 Sobre el rol del juez en los Estados Unidos durante el juicio, ver, por ejemplo Bradley, C. M., "United States", en Criminal Procedure: a Worldwide Study, Carolina Academic Press, 1999, pp. 395, 421-22.

${ }^{44}$ Por un análisis reciente -en el contexto del debate en Estados Unidos respecto a la política de las "ventanas rotas"- sobre cómo el derecho penal y las prácticas de la justicia penal pueden moldear a los sujetos sociales, ver Harcourt, B. E., Illusion of order: The false promise of broken windows policing, Harvard University Press, 2009, p. 160 
De los trasplantes legales a las traducciones legales: la globalización del plea...

luchas, entre dos sistemas abstractos de sentido ${ }^{45}$. Al incluir esta dimensión de las disposiciones individuales quiero enfatizar que, además de estas interacciones entre dos sistemas abstractos - que, nuevamente, tal como los concibo se inscriben en prácticas sociales concretas - cada trasplante legal también involucra interacciones entre personas concretas con un conjunto concreto de disposiciones individuales.

Además, esta dimensión también es importante para entender cómo los sistemas procesales - y cualquier otras estructuras de interpretación y sentido- pueden cambiar con el tiempo. La relación entre las estructuras procesales de sentido y las disposiciones individuales es de mutua influencia. Las disposiciones individuales son influenciadas por las estructuras de sentido a punto tal que los actores individuales adquieren, mediante una serie de procesos de socialización, un sistema de interpretación concreto que, en cierta medida, los "configura" para actuar y reaccionar de determinada manera. Pero si un número importante de actores internaliza una estructura de sentido diferente (i.e., cuando los abogados de las jurisdicciones continentales europeas y latinoamericanas estudian en los Estados Unidos y adquieren parcialmente una estructura de sentido acusatoria), esto puede conducirlos a cuestionar la estructura de sentido predominante (i.e., la inquisitiva) e intentar incorporar prácticas de otros sistemas legales — como el plea bargaining — en sus propios sistemas legales ${ }^{46}$.

\subsubsection{Poderes procesales}

Por último, lo acusatorio y lo inquisitivo difieren en otro nivel que aquí llamo el de la "dimensión del poder procesal" ${ }^{47}$. Los principales actores del

45 Ver, por ejemplo, Teubner, G., "Legal Irritants: Good Faith in British Law or How Unifying Law Ends Up in New Divergences", Modern Law Review, vol. 61, (1998), p. 11.

${ }^{46}$ Sobre la influencia que la educación legal estadounidense puede tener en los procesos de "americanización" de las normas y prácticas jurídicas europeas, ver Wiegand, W., "Americanization”, op. cit., pp. 139-40.

${ }^{47}$ La dimensión del poder procesal también ha sido relativamente ignorada por los estudios del proceso penal comparado, y es central no sólo para describir las diferencias entre los sistemas acusatorio e inquisitivo, sino también para identificar los posibles lugares 
proceso penal - jueces, fiscales, abogados defensores, imputados, policía, etc. - tienen diferentes cuotas de poderes y responsabilidades procesales en cada sistema. Desde esta perspectiva, por ejemplo, el órgano decisor inquisitivo, en tanto que investigador activo, tiene más poderes procesales - v.g., actuar sua ponte - que el órgano decisor acusatorio ${ }^{48}$. Esto también significa que en el sistema inquisitivo la fiscalía y la defensa tienen comparativamente menos poderes que en el sistema acusatorio. Un ejemplo de ello es la potestad que tiene la defensa en el sistema acusatorio de llevar a cabo su propia investigación preliminar - una potestad que generalmente no se encuentra en los sistemas inquisitivos $-{ }^{49}$. La variación de los poderes procesales que tienen los actores individuales también se puede apreciar al nivel institucional, en las relaciones de poder entre la fiscalía, el poder judicial, los colegios de abogados, las defensorías públicas, la policía, etc. ${ }^{50}$.

La dimensión del poder procesal también tiene una relación de mutua influencia con las estructuras de sentido y las disposiciones internas. Por ejemplo, una estructura de interpretación y sentido inquisitiva le otorga al

de resistencia hacia las reformas judiciales en los entornos institucionales acusatorios e inquisitivos.

${ }^{48}$ Esto es claro si comparamos a los jueces activos del sistema inquisitivo con el jurado del acusatorio. Los jueces inquisitivos también tienen más poder que los jueces profesionales acusatorios debido a sus poderes para decidir qué pruebas se producirán en el juicio y el orden en el cual se presentarán, así como a través de sus poderes para conducir el interrogatorio de testigos y peritos. Sin embargo, esta última afirmación debe ser matizada. Los jueces del acusatorio tienen poderes inherentes - i.e., poder de sancionar por desacatoque los del inquisitivo carecen. Además, como hay menos control jerárquico sobre las decisiones de los jueces del acusatorio que los del inquisitivo, los primeros también tienen más poder en este sentido.

${ }^{49}$ Con respecto a Francia, ver, por ejemplo, Dervieux, V., "The french system”, en Delmas-Marty, Mireille, and John R. Spencer (eds.) European criminal procedures, Vol. 25, Cambridge University Press, 2002, pp. 218-291.

${ }^{50}$ Aunque a los fines de este artículo no es necesario una elaboración más extensa de esta categoría, también incluyo dentro de esta dimensión de los poderes procesales e institucionales no sólo a la relación entre los principales actores e instituciones permanentes del sistema de justicia penal, sino también a las relaciones entre los actores profesionales permanentes y los legos. En el sistema inquisitivo, el poder de los legos como órganos decisores es mínimo o inexistente. En el sistema acusatorio, es mucho más importante, al menos en términos comparativos. Ver, por ejemplo. Kagan, R., Adversarial legalism: The American way of law, Harvard University Press, 2009. 
De los trasplantes legales a las traducciones legales: la globalización del plea...

juez amplios poderes de investigación, mientras que le concede poderes más limitados a la fiscalía y la defensa. Pero, al mismo tiempo, cualquier intento de modificar esta estructura de interpretación y sentido por lo general va a producir una resistencia por parte de los jueces contra la pérdida de sus poderes que acarrearía la adaptación de una nueva estructura procesal de sentido ${ }^{51}$.

Esto conduce a una cuestión de suma importancia. Aun cuando he presentado a las dimensiones de la estructura de interpretación y sentido, las disposiciones personales y los poderes procesales e institucionales como analíticamente diferentes, lo cierto es que operan conjuntamente y tienden a reforzarse, aunque eventualmente también pueden subvertirse las unas a las otras.

\subsubsection{Otros elementos de los sistemas}

Las interacciones entre estas tres dimensiones tienen otras implicancias. Las estructuras procesales de interpretación y sentido acusatorias e inquisitivas no sólo son las "lentes" a través de las cuales los actores legales entienden y operan en la realidad. También constituyen dos órdenes normativos que indican, hasta cierto punto, cómo deben manejarse los casos, qué tecnologías deben utilizarse, cómo deben comportarse cada uno de los actores del sistema, etc.

${ }^{51}$ La implementación del Código de Procedimientos Penal de la provincia de Buenos Aires de 1998 brinda un ejemplo de este fenómeno. Este código trasladó la responsabilidad de realizar la investigación preliminar de los jueces a los fiscales. Consecuentemente, un importante número de jueces resistieron esta reducción de sus poderes y responsabilidades procesales. Esta resistencia se puso de manifiesto, por ejemplo, en la llamada "guerra de las fotocopias". Al solicitar órdenes de allanamiento los fiscales investigadores presentaban a los jueces copias certificadas del expediente escrito que contenían la información pertinente, en lugar de enviarles los originales, como forma de acelerar los procedimientos. Varios jueces consideraron que esto representaba una cuestión simbólica con respecto a quién estaba realmente a cargo de la investigación. Como consecuencia dijeron que no otorgarían esas órdenes a menos que recibieran los expedientes originales. Estas controversias arruinaron varias investigaciones y se convirtió en una cuestión tan seria que la Suprema Corte de la provincia tuvo que intervenir. Ver, por ejemplo, Saralegui, F., Demora judicial en San Isidro por una disputa, La Nación (Arg.), 6 de junio de 2000, p. 1, disponible en http:// lanacion.com.ar/Archivo/Nota.asp?nota_id=19704 (última visita del 25 de noviembre de 2003) (en archivo con Harvard International Law Journal). 
Por ejemplo, ellas determinan en cierto modo cómo se estructuran y administran los recursos materiales y humanos. Esto es lo que ocurre con las distintas técnicas de administración de casos que existen en cada sistema. En el sistema inquisitivo, la columna vertebral de todo el proceso y una de sus principales herramientas de administración de casos es el expediente, desde las primeras etapas del procedimiento, en donde interviene la policía, hasta la fase recursiva contra la sentencia ${ }^{52}$. Por el contrario, en el sistema acusatorio las audiencias orales y públicas juegan un rol importante en la administración de los casos - aun en aquellos en los que se llega a un acuerdo $-{ }^{53}$. Del mismo modo - como lo veremos luego con más detalle - hasta hace poco tiempo el plea bargaining ha sido una herramienta desconocida para la administración de los casos en los sistemas inquisitivos ${ }^{54}$ pese a que ha sido permitido, $y$ ampliamente utilizado, en las jurisdicciones anglosajonas ${ }^{55}$.

Esto no significa, sin embargo, que las dimensiones de la estructura procesal de sentido, las disposiciones internas y los poderes procesales influyen en la distribución de los recursos humanos y materiales, en la ética profesional, en el sistema interno de incentivos, etc., en forma unidireccional. Este conjunto de factores se influye mutuamente. Por ejemplo, la existencia de un expediente escrito, una herramienta para la administración de casos que contiene todos los elementos de prueba recolectados durante la etapa preliminar, es necesaria para que el juez del debate actúe como un investigador

52 Para una descripción del rol que tiene el expediente escrito en los sistemas inquisitivos, ver Schlesinger, R. B., "Comparative Criminal Procedure: A Plea for Utilizing Foreign Experience”, Buffalo Law Review, vol. 26, 1977, pp. 361, 365- 67

${ }^{53}$ Sobre la preferencia por la producción oral del testimonio en audiencia pública en los Estados Unidos, ver Federal Rules of Criminal Procedure Regla 26. Respecto a la importancia de la comunicación oral en el proceso penal de Inglaterra, ver Damaška, M., op. cit, en nota 24, p. 61.

${ }^{54}$ Puede verse un análisis clásico, en. Langbein, J. H., "Land Without Plea Bargaining: How the Germans Do It", Michigan Law Review, vol, 78, 1979, p. 204.

${ }^{55}$ Para estudios históricos de cómo se desarrolló la práctica del plea bargaining en Estados Unidos, ver Alschuler, A. W., "Plea Bargaining and Its History", Law and Society Review, vol. 13, 1979, p. 211, Fisher, G., "Plea Bargaining's Triumph”, Yale Law Review, vol. 109, 2000, p. 857, Friedman, L. M., "Plea Bargaining in Historical Perspective", Law and Society Review, vol. 13, 1979, p. 247 y Langbein, J. H., "Understanding the Short History of Plea Bargaining”, Law and Society Review, vol. 13, 1979, p. 261. 
De los trasplantes legales a las traducciones legales: la globalización del plea...

activo durante el juicio ${ }^{56}$. Si el expediente no existiera, por ejemplo, debido a su supresión por una reforma legal, el juez del debate no podría comportarse de esa forma activa, no podría organizar el juicio de antemano, ni interrogar a los testigos de manera eficiente, etc., y las partes ganarían poderes procesales a su costa ${ }^{57}$. Si esta reforma sobreviviera, podría producir un cambio en las disposiciones internas de los jueces, fiscales y abogados defensores del sistema inquisitivo de modo tal que empezarían a actuar en forma diferente: los jueces de manera más pasiva, las partes de manera más activa, etc. Este cambio en las prácticas procesales penales (parole), a su turno, provocarían un cambio en la estructura inquisitiva de interpretación y sentido (langue), y en la dimensión del poder procesal.

Estas relaciones multi-direccionales entre las tres dimensiones descriptas y los recursos materiales y humanos, las técnicas de administración de casos, la ética profesional, etc., van a ser de suma importancia para analizar por qué y cómo los procesos penales inquisitivos y acusatorios cambian con el tiempo, incluyendo los cambios producidos por la transferencia de ideas e instituciones legales.

\subsubsection{Puntos de énfasis}

Hay dos últimas cuestiones que merecen ser enfatizadas. Primero, como las categorías acusatorio e inquisitivo existen dentro de prácticas procesales penales concretas de las jurisdicciones anglosajonas y continentales europeas y latinoamericanas, se encuentran constantemente cuestionadas y sometidas a cambios. Por ejemplo, cada vez que un juez particular de los Estados Unidos interroga de forma activa a los testigos (o permite hacerlo a los jurados), hay un cuestionamiento a la estructura de interpretación y sentido acusatoria.

${ }^{56}$ Ver, por ejemplo, Damaška, M., "Aspectos globales de la reforma del proceso penal”, Reformas a la Justicia penal en las Américas. www. dplf. org/Fundación para el debido proceso legal, 2000.

57 Esta era, precisamente, la idea detrás del artículo 431 del Código Procesal Penal de Italia de 1989, que eliminó el acceso completo de los jueces del debate al expediente escrito confeccionado durante la etapa preliminar. Ver Codice di Procedura Penale, art. 431. Para un análisis de esta reforma, ver Grande, E., op. cit., pp. 243-44. 
No obstante, el hecho de que esos cuestionamientos ocurran todo el tiempo no significa que los sistemas acusatorio e inquisitivo no existan dentro de estas prácticas procesales penales. La concepción general del sistema sigue siendo altamente predominante dentro de estas prácticas, aun cuando existan varias excepciones y cuestionamientos. En este sentido, no considero que estas culturas procesales - como la cultura en general- sean homogéneas. Mi afirmación empírica es que las culturas procesales acusatoria e inquisitiva siguen siendo altamente predominantes en las jurisdicciones anglosajonas así como en las continentales europeas y latinoamericanas respectivamente, incluso al día de hoy, al menos en lo que se refiere a los procedimientos formales para determinar la culpabilidad o la inocencia.

Segundo, aun cuando las categorías acusatorio e inquisitivo han sido altamente predominantes durante los procedimientos formales para determinar la culpabilidad o inocencia, ello no significa que sean las únicas estructuras de interpretación y sentido que existen respectivamente en los sistemas de justicia penal de las jurisdicciones anglosajonas (common law) y continentales europeas y latinoamericanas y similares (civil law $)^{58}$. De

${ }^{58} \mathrm{El}$ análisis en detalle de esta cuestión excede los límites de este artículo. Pero quisiera señalar cuatro puntos de importancia. Primero, existen diferencias procesales locales que no pueden ser reducidas a estas estructuras de sentido globales. Por ejemplo, en Francia la fiscalía pertenece al Poder Ejecutivo, en Italia al Judicial y en Argentina es una institución independiente de los tres poderes tradicionales de gobierno. Estas diferentes posiciones institucionales tienen implicancias con respecto a cómo es entendido que es un fiscal en estos tres países, i.e. cuán independientes son del Poder Ejecutivo (para un análisis de las relaciones entre la independencia de los fiscales y la posición institucional de la fiscalía en el contexto latinoamericano, ver Heymann, P. B., "Should Latin American Prosecutors be Independent of the Executive in Prosecuting Government Abuses?", University of Miami Inter-american Law Review, vol. 26, 1995, p. 535). Estos diferentes sentidos, además, no pueden ser reducidos a las estructuras de sentido inquisitivas y acusatorias (para un análisis sobre las consecuencias de estas distintas posiciones institucionales de los fiscales en Francia e Italia, ver Guarnieri, C., "Prosecution in Two Civil Law Countries: France and Italy", en Nelken, D., Comparing legal cultures, Routledge, 1997, p. 183). Segundo, en cada jurisdicción concreta generalmente hay otras estructuras de interpretación y sentido en el proceso penal y, de manera más amplia, en el sistema de justicia penal, que compiten o complementan a lo acusatorio y lo inquisitivo. Por ejemplo, en Estados Unidos durante la mayor parte del siglo XX la etapa de la determinación de la pena no ha estado estructurada o influenciada por el sistema acusatorio, sino por una concepción mas bien paternalista del procedimiento que considera al condenado como una persona peligrosa o enferma 
De los trasplantes legales a las traducciones legales: la globalización del plea...

todas maneras, pese a la existencia de estas otras estructuras de interpretación y sentido que operan a nivel procesal, legal y social, sería equivocado subestimar la gran importancia de lo acusatorio y lo inquisitivo. Lo acusatorio y lo inquisitivo han ejercido una influencia determinante en las prácticas, normas, estructuras organizacionales, sistemas de incentivos, etc., del proeso penal en las jurisdicciones anglosajonas y continentales europeas y latinoamericanas, especialmente durante la etapa de la determinación de la culpabilidad o inocencia. Aun cuando determinados análisis específicos deban considerar las particularidades locales, y las influencias sociales,

que debe ser rehabilitada (para un análisis sobre la etapa de fijación de la pena en Estados Unidos durante la mayor parte de este siglo, y cómo cambió con la introducción de las Federal Sentencing Guidelines, ver, por ejemplo, Stith, K. y Cabranes, J. A., "Judging Under the Federal Sentencing Guidelines", Northwestern University Law Review, vol. 91, 1997, p. 1247). Incluso en la etapa de determinación de la culpabilidad, en donde el sistema acusatorio ha prevalecido por mucho tiempo en Estados Unidos, hay procedimientos específicos que están organizados según una estructura inquisitiva de sentido, como aquellos que se realizan ante el gran jurado. Sobre el carácter inquisitivo del gran jurado, ver, por ejemplo, Goldstein, A. S., "Reflections on Two Models: Inquisitorial Themes in American Criminal Procedure", en Stanford Law Review, vol. 26, 1974, pp. 1009-1020. Para una propuesta de introducir más protecciones acusatorias en el procedimiento ante el gran jurado, ver Arenella, P., "Reforming the Federal Grand Jury and the State Preliminary Hearing to Prevent Conviction without Adjudication", en Michigan Law Review, vol. 78, 1980, p. 463. Tercero, existen otras estructuras de interpretación y sentido relacionadas no sólo con el sistema de justicia penal, sino también con el sistema legal como un todo. Y si bien algunas de estas estructuras pueden ser reducidas a distinciones globales entre las jurisdicciones anglosajonas y continentales europeas y latinoamericanas y similares - i.e., el razonamiento legal del primero se basa más en las inferencias analógicas, mientras que el segundo lo hace en las deductivas - existen otras diferencias con las cuales ello no puede hacerse. Por ejemplo, mientras algunos países tienen un sistema federal otros no, y esta diferencia no parece originarse en los sistemas acusatorio e inquisitivo. Finalmente, también hay otras estructuras de interpretación y sentido (políticas, económicas, religiosas, de los medios de comunicación, etc.) que exceden la esfera legal, pero que pueden afectar el modo en que el proceso penal y los actores de la justicia penal son entendidos. Por ejemplo, el juez de la investigación preliminar -juge d'instruction en los países francófonos, juez de instrucción en España y América Latina - muchas veces es representado en el imaginario social francés como el pequeño funcionario que "hace que la verdad surja" por medio de la lucha "contra los poderosos, la fuerza de la tinta y el derecho, frente al dinero y el poder" y, al mismo tiempo, es una figura emblemática de las provincias en su lucha contra París. Garapon, a., op. cit., supra nota 37, pp. 497-98. Esta es una representación social del juez de la investigación preliminar que generalmente no se encuentra en otros sistemas inquisitivos, como, por ejemplo, en Argentina. 
económicas y políticas en el proceso penal, sería erróneo no atender a estas diferencias o similitudes globales de gran importancia. Para usar una metáfora tomada de la moderna teoría de los sistemas, se podría decir que los sistemas anglosajones y continentales europeos y latinoamericanos comparten respectivamente el mismo programa acusatorio o inquisitivo, $o$ uno similar, aun cuando este programa coexista con otros programas legales y sociales en cada jurisdicción particular ${ }^{59}$. Estos programas deben ser conceptualizados adecuadamente para analizar las similitudes y diferencias entre las jurisdicciones anglosajonas y continentales europeas y latinoamericanas, así como la circulación de ideas e instituciones legales entre ellas, y también para discutir los matices de la tesis de la "americanización".

\section{El contenido de la dicotomía: acusatorio vs. inquisitivo}

Luego de haber explicado las bases de los sistemas acusatorio e inquisitivo como categorías teóricas, hay dos oposiciones binarias que voy a utilizar en esta sección para explicar las principales diferencias entre estos sistemas. Primero, mientras que el sistema acusatorio concibe al proceso penal como una disputa entre la fiscalía y la defensa ante un árbitro pasivo, el sistema inquisitivo lo concibe como una investigación oficial llevada a cabo por funcionarios públicos para determinar la verdad. Segundo, mientras que el órgano decisor del sistema acusatorio es un jurado que comparte su trabajo con un juez profesional, el del sistema inquisitivo es un juez profesional, o un grupo de ellos, que no comparten su responsabilidad con ningún otro órgano ${ }^{60}$. Estas oposiciones binarias explican algunas de las diferencias entre el sistema acusatorio de los Estados Unidos con los sistemas inquisitivos de Alemania, Italia, Argentina y Francia.

59 Ver Teubner, G., “The Two Faces of Janus: Rethinking Legal Pluralism”, Cardozo Law Review, vol 13, 1992, pp. 1443, 1455.

${ }^{60}$ Como explico luego, los jueces profesionales pueden compartir sus responsabilidades con legos en los tribunales mixtos. Sin embargo, incluso en este caso los jueces profesionales generalmente mantienen el control del proceso de toma de decisión, dado que son actores profesionales y permanentes. Además, hay un solo órgano decisor compuesto por jueces profesionales y legos, en lugar de dos -el juez y el jurado- como ocurre en el sistema acusatorio. 
De los trasplantes legales a las traducciones legales: la globalización del plea...

Intentar definir a los sistemas acusatorio e inquisitivo a los fines del derecho comparado es una tarea complicada al menos por cuatro motivos distintos $^{61}$. Primero, las diferencias entre los procesos penales de la tradición anglosajona y la tradición continental europea y latinoamericana pueden rastrearse hasta el siglo XIII, cuando Inglaterra y Europa desarrollaron distintos sistemas para reemplazar a las prácticas imperantes de entonces que habían tenido lugar desde la caída del Imperio Romano de Occidente ${ }^{62}$. Estas diferencias han evolucionado con el tiempo y explicar sus evoluciones paralelas excede el objeto de este artículo ${ }^{63}$.

Segundo, como consecuencia de fenómenos como la colonización, "civilización" y "modernización", cada una de estas dos tradiciones se ha expandido a punto tal de incluir un importante número de países con dife-

${ }^{61}$ Las expresiones "acusatorio" e "inquisitivo" ya eran utilizadas durante el siglo XII en Europa para "distinguir un proceso que requería la promoción de un demandante privado para ponerse en marcha (processus per accusationem), de uno que podía iniciarse en su ausencia (processus per inquisitionem)". Damaška, M., Faces of Justice..., op. cit. , p. 3. Es posible que el uso moderno de estas expresiones, que conciben a lo acusatorio y lo inquisitivo no sólo como dos formas distintas de inicio del proceso, sino también como dos sistemas procesales integrales, se haya desarrollado durante el siglo XIX. Según mi conocimiento el primer uso que se hizo en este sentido fue de Hélie, F., Traité de l'instruction criminelle ou Théorie du code d'instruction criminelle, vol. 5, 1853, pp. 47-65.

${ }^{62}$ Para una descripción del sistema de ordalías, juicios de Dios y juramentos, que prevaleció en Europa previo al siglo XIII y una explicación de su desaparición, ver Bartlett, R., Trial by Fire and Water: The Medieval Judicial Process, Oxford, Clarendon Press, 1986.

${ }^{63}$ Una clásica explicación es Esmein, A., Histoire de la procédure criminelle en France: et spécialement de la procédure inquisitoire depuis le XIIIe siècle jusqu'a nos jours, L. Larose et Forcel, 1882. Hay una versión en inglés de este trabajo con traducción de John Simpson. Para análisis contemporáneos de estos desarrollos, ver Cordero, F., Procedura Penale, Giuffré, 1993; Langbein, J. H., and Simpson, AW B., The origins of adversary criminal trial, Oxford University Press, 2003; Langbein, J. H., Torture and the law of proof: Europe and England in the Ancien Régime, University of Chicago Press, 1977; Maier, J. B. J., Derecho procesal penal, Vol. 1, Buenos Aires, Editores del Puerto, 1996; Royer, J. P., "Histoire de la Justice En France de la Monarchie Absolue À la République”, 1995. No me refiero a la "evolución" como progreso o movimiento hacia la perfección, sino simplemente como un cambio a través del tiempo. Para un análisis interesante respecto al uso de este término en la teoría de los sistemas, ver Teubner, G., "Legal Irritants: Good Faith in British Law, or How Unifying Law Ends Up in New Divergences", en Modern Law Review, vol. 61, 1998 pp. 11, 15-16, 27-32. 
rentes reglas y prácticas legales propias, lo cual complica los esfuerzos para captar las diferencias y similitudes entre estos sistemas ${ }^{64}$.

Tercero, tanto en las jurisdicciones anglosajonas como en las continentales europeas y latinoamericanas, las expresiones "adversarial" (o "acusatorio" $\left.{ }^{65}\right)$ e "inquisitivo" están cargadas con connotaciones políticas y culturales; por ejemplo, generalmente la tradición acusatoria está vinculada a concepciones democráticas o liberales, en tanto que la tradición inquisitiva está asociada a concepciones autoritarias del proceso penal ${ }^{66}$. Esto ha llevado a lo que podría llamarse una batalla retórica por la apropiación de estos términos, lo cual, a su vez, ha multiplicado sus distintos usos ${ }^{67}$. De hecho, como consecuencia de estas connotaciones, lo "acusatorio" y lo "inquisitivo" han sido términos centrales o "significados flotantes" a través de los cuales los actores de las tradiciones anglosajona y continental europea y latinoamericana han definido y diferenciado su propia identidad, tanto con respecto a la identidad de otras tradiciones como la de su propio pasado $^{68}$.

${ }^{64}$ Sobre la expansión del common law en el mundo, ver Zweigert, K. and Hein, K., Introduction to comparative law, Oxford University Press, $3^{\text {a }}$ ed. 1998, pp. 218-37 (3d ed. 1998). Puede verse una descripción sobre el modo en que el sistema inquisitivo se impuso y desarrolló en América Latina en Maier, op. cit. Para un análisis de estos desarrollos en varios países de África, Asia y América, ver Pradel, J., Droit pénal comparé, Dalloz, 2002, pp. 186-201.

65 Abraham S. Goldstein intentó trazar una distinción entre los terminos "adversarial" - como una forma de establecer los hechos y aplicar las normas - y "acusatorio" - que incluiría no sólo los procedimientos adversariales del juicio, sino una concepción del Estado como neutral en las disputas-. Sin embargo, en este artículo trato estos términos como equivalentes. Ver Goldstein, A. S., "Reflections on Two Models: Inquisitorial Themes in American Criminal Procedure”, Stanford Law Review, vol. 26, 1974, pp. 1009, 1017

${ }^{66}$ Para Argentina, ver, por ejemplo, Maier, J. B. J., Derecho Procesal Penal, op. cit. , $₫ 5(\mathrm{H})(1)$ (a)- (b). Para Francia, ver, por ejemplo, Pradel, J., "Inquisitoire-Accusatoire: une redoutable complexité", International Review of Penal Law, vol. 68, 1997, pp. 213, 215. Para Alemania, ver, por ejemplo, Roxin, C. and Bernd, S., Strafverfahrensrecht, München, 1998, 25. Auflage $\$ 2$, pp. 9-11. Para Italia, ver, por ejemplo, Ferrajoli, L., Diritto e Ragione. Teoría del garantismo penale, Bari, Ed. Laterza, 1989, pp. 576, 655 n.84. Para Estados Unidos, ver, por ejemplo, Miranda v. Arizona, 384 U.S. 436, 442-43, 459-60 (1966).

67 Ver Langer, M., op. cit., supra nota 23, pp. 102-14.

${ }^{68}$ En Estados Unidos la palabra "acusatorio" ha sido utilizada en términos elogiosos en referencia al proceso penal estadounidense que tuvo sus orígenes en Inglaterra, en las luchas por los derechos contra la monarquía autoritaria, las cuales continuaron en las colonias y que finalmente se plasmaron en el Bill of Rights. En esta construcción de lo acusatorio, lo 
De los trasplantes legales a las traducciones legales: la globalización del plea...

Por último, aun cuando sea posible identificar diferencias históricas entre los procesos penales anglosajones y los continentales europeos y latinoamericanos que han durado hasta el presente, lo cierto es que no siempre se pueden reducir estas diferencias a un principio explicatorio común. Por ejemplo, los plea bargainings y las reglas probatorias detalladas han sido tradicionalmente asociadas con los procesos penales anglo-americanos y considerados inexistentes en la mayoría de las jurisdicciones continentales europeas y latinoamericanas ${ }^{69}$. No obstante, las explicaciones históricas y analíticas de estas dos características no pueden ser reducidas a una única fuente. Los Plea bargains parecen haber tenido su origen en un proceso penal entendido como una disputa entre partes, mientras que las reglas

inquisitivo se refiere al proceso penal contemporáneo de Europa que sigue siendo considerado autoritario -v.gr., provocando confesiones en forma coercitiva-. Para un ejemplo de esta construcción de lo acusatorio y lo inquisitivo en Estados Unidos, ver Miranda, 384 U.S. pp. 442-43, 459-60 (para otro uso de los términos en Estados Unidos que no es presentado en forma elogiosa, y que se focaliza en el rol del juez en cada uno de estos sistemas, ver, por ejemplo, McNeil v. Wisconsin, 501 U.S. 171, 181 n.2 (1991)). En Europa continental uno de los usos más generalizados de lo acusatorio y lo inquisitivo para definir la identidad de su proceso penal moderno ha sido la siguiente. Lo acusatorio se usa para referirse al procedimiento penal moderno anglosajón -y aquellos que prevalecieron en la Europa continental desde la caída del Imperio Romano de Occidente hasta el siglo XIII- considerados generalmente ineficientes en términos del cumplimiento de la ley. Lo inquisitivo se refiere a los procesos penales que prevalecieron en la Europa continental desde el siglo XIII hasta el XIX, y que generalmente se los considera como autoritarios. Los procesos penales modernos de Europa continental constituirían un sistema mixto que combina lo mejor de los otros dos sistemas. Para un ejemplo de este uso a comienzos del siglo XX en Francia, ver Garraud, R. and Pierre G., Traité théorique et pratique d'instruction criminelle et de procédure pénale, Vol. 1, Sirey, 1907, pp. 10-22. Hélie utiliza el término en el mismo sentido, op. cit., pp. 47-65. Para un uso contemporáneo de estos términos en América Latina, ver Maier, M., Derecho Procesal Penal, op. cit. $\$ 5(H)(1)(a)-(c)$, pp. 443-54, aunque este autor es muy crítico del sistema mixto. No conozco otros autores que hayan analizado lo inquisitivo y lo acusatorio como categorías centrales o significantes a través de las cuales han sido definidas las identidades de los actores de la tradición anglosajona y de la tradición continental europea y latinoamericana. Entender estos procesos de definición de identidad podría abrir nuevas puertas para el análisis comparado del proceso penal. Por ejemplo, podrían ser de utilidad para entender por qué los actores de Europa continental y América Latina han estado interesados en adoptar instituciones e ideas del sistema anglosajón y no al contrario. Para un reciente análisis de las tradiciones legales como identidades, ver Glenn Patrick, H., Legal Traditions of the World, Oxford University Press, 2000.

${ }^{69}$ Ver, por ejemplo, Langbein, J. H., Comparative, op. cit. pp. 68-71. 
de evidencia detalladas parecen estar principalmente vinculadas a la existencia de un tribunal bifurcado en donde un órgano - el juez- decide qué prueba es admitida en el juicio, y otro órgano - el jurado- decide la culpabilidad o inocencia del acusado ${ }^{70}$.

En este artículo abordo estos problemas de la siguiente manera. Primero, con respecto a los cambios de los sistemas en el tiempo, me focalizo principalmente en los procesos penales contemporáneos de los sistemas continentales europeos y latinoamericanos antes de que introdujeran las específicas reformas acusatorias analizadas en las próximas secciones. Segundo, con relación a la pluralidad de jurisdicciones que pueden ser incluidas en las categorías acusatorio e inquisitivo, he decidido concentrarme sólo en cinco. Cuando me refiero al sistema acusatorio me estoy refiriendo a las jurisdicciones estadounidenses, y cuando me refiero a los sistemas inquisitivos me estoy refiriendo a los procesos penales de Alemania, Italia, Argentina y Francia. Tercero, en lo que se refiere a las connotaciones políticas de los términos "acusatorio" e "inquisitivo", es necesario remarcar que los utilizo sólo como herramientas descriptivas a los fines del derecho comparado. Por último, en lugar de intentar comprender las diferencias entre los sistemas a través de un principio explicatorio, identifico dos modelos dentro de cada sistema como las bases de la comparación ${ }^{71}$.

${ }^{70}$ Id. pp. 70-71. Para un estudio sobre por qué las reglas de evidencia anglosajonas existen con su configuración actual y cómo se relacionan con otras características del sistema anglosajón, ver Damaška, M., Evidence law adrift, Yale University Press, 1997. Damaška considera que la existencia del jurado no ha jugado un rol tan central como generalmente se sostiene. Id. pp. 26-57.

${ }^{71}$ Dada mi conceptualización de los sistemas acusatorios e inquisitivos como culturas procesales, existe un quinto problema para dotar de contenido a ambas categorías. Como expliqué en la sección II, estas culturas no son completamente homogéneas y dentro de las prácticas procesales penales de Estados Unidos, Argentina, Francia, Alemania e Italia se pueden identificar distintas visiones sobre las características de cada una de estas culturas legales. Así, el hecho de darle un sentido particular a cada una de estas culturas legales puede silenciar o suprimir algunas de las visiones alternativas, y puede contribuir a que prevalezca una visión sobre las otras. La primera manera de lidiar con este problema es mediante su reconocimiento, en otras palabras, siendo consciente y reflexivo al respecto. Además, considero que los sistemas acusatorios e inquisitivos, tal como los defino en esta sección, han sido abrumadoramente predominantes en estas cinco jurisdicciones -al menos durante la etapa de la determinación de la culpabilidad-. Por lo tanto, en este artículo me concentraré en estas concepciones predominantes de lo acusatorio y lo inquisitivo, porque 
De los trasplantes legales a las traducciones legales: la globalización del plea...

El primer par de modelos a los fines comparativos son el modelo de la disputa (una característica del sistema acusatorio) y el modelo de la investigación oficial (una característica del sistema inquisitivo) ${ }^{72}$. Según el primer modelo, el proceso penal es entendido como una disputa o contienda entre dos partes, la fiscalía y la defensa, ante un órgano decisor pasivo. La disputa se centra alrededor de la pretensión de la fiscalía de probar más allá de toda duda razonable que el acusado cometió el delito que se le acusa. Si logra hacerlo, entonces la fiscalía gana; si fracasa, gana el acusado.

Hay muchas características del proceso penal anglosajón que pueden ser explicadas a través de este modelo. Por ejemplo, las amplias facultades discrecionales en la persecución penal encajan en este modelo porque la fiscalía, en tanto que una de las partes en disputa, puede considerar que no hay controversia en un caso particular, o bien decidir que no vale la pena la persecución penal y por ende no está obligada a llevarla adelante ${ }^{73}$. Las declaraciones de culpabilidad encajan en este modelo porque la defensa, en tanto que la otra parte de la disputa, puede conceder que la contraparte

son las más útiles para explicar cómo entienden el proceso penal los actores legales en cada una de estas jurisdicciones, y así cómo se transformó el plea bargaining cuando fue adoptado por nuestros cuatro países de la tradición continental europea y latinoamericana. Los trabajos que se focalizan en las voces culturales disidentes en cada una de estas jurisdicciones y en la heterogeneidad de las culturas acusatoria e inquisitiva son de gran valor, pero forman parte de una tarea distinta a la que llevo adelante en este artículo.

72 La idea de la disputa y de la investigación ha sido utilizada a los fines del derecho comparado durante mucho tiempo. Ver, por ejemplo, Helie, F., op. cit., p. 53.

${ }^{73}$ Para estudios sobre la amplia discrecionalidad que tienen los fiscales estadounidenses ver, por ejemplo, Abrams, N., "Prosecution: Prosecutorial Discretion", en Kadish, S. H., Encyclopedia of Crime and Justice (Volume 3), The Free Press Macmilan Publisher, New York, 1983, p. 1272; Frase, R. S., “The Decision to File Federal Criminal Charges: A Quantitative Study of Prosecutorial Discretion”, University of Chicago Law Review, vol. 47, 1980, p. 246; Krug, P., "Prosecutorial Discretion and its Limits" American Journal of Comparative Law, vol. 50, 2002, p. 643; LaFave, W. R., "The Prosecutor's Discretion in the United States" American Journal of Comparative Law, vol. 18, 1970, p. 532; Misner, R. L., "Recasting Prosecutorial Discretion", Journal of Criminal Law and Criminology, vol. 86, 1996, p. 717; Vorenberg, J., “Decent Restraint of Prosecutorial Power", Harvard Law Review, vol. 94, 1981, p. 1521. Para análisis clásicos acerca de cómo lidiar con el problema de la discrecionalidad en el sistema de justicia penal, con respecto a las prácticas no solo de los fiscales, sino también de otros actores legales, ver Davis, K. C., Discretionary justice: A preliminary inquiry, LSU Press, 1969; Rosett, A., "Discretion, Severity and Legality in Criminal Justice", Southern California Law Review, vol. 46, 1972, p. 12. 
tiene razón y por ende resolver la controversia; la determinación de culpabilidad o inocencia finaliza ${ }^{74}$ y el caso pasa a la siguiente etapa para la fijación de la pena. Si el proceso penal es visto como una disputa, entonces la estructuración del proceso como la de dos casos que compiten y están en colisión encuadra perfectamente en esta concepción. Por ende, en las jurisdicciones anglosajonas cada parte de la disputa realiza su propia investigación preliminar ${ }^{75}$, aun cuando las partes deben parcialmente revelar la información obtenida a la parte contraria a través de reglas y procedimientos de descubrimiento de elementos de prueba ${ }^{76}$. El juicio se divide en el caso de la fiscalía y el caso de la defensa; las partes generalmente deciden en qué orden se presentará la prueba; los testigos y peritos pertenecen a la fiscalía o la defensa ${ }^{77}$; y el interrogatorio de los testigos es realizado como una disputa entre dos partes, con un examen directo y contra-interroga-

${ }^{74}$ Ver, por ejemplo, Fed. R. Crim. p. 11(c)(4).

${ }^{75}$ Sobre el deber del abogado defensor en los Estados Unidos de efectuar investigaciones razonables, o tomar decisiones razonables en cuanto a la innecesariedad de una investigación particular, ver Wiggins v. Smith, 123 S. Ct. 2527 (2003); Strickland v. Washington, 466 U.S. 668, 691 (1984).

${ }^{76}$ De hecho, hasta la promulgación de la Regla Federal de Procedimiento Penal 16 en el año 1946, no existía el derecho a obtener información y elementos de prueba colectados por la parte contraria. Ver Miller, F. W., et al. Criminal Justice Administration: Cases and Materials, Foundation Press, 2000, p. 753. Hoy en día las reglas de descubrimiento se basan en la Constitución según la doctrina Brady, Strickler v. Greene, 527 U.S. 263 (1999); Kyles v. Whitley, 514 U.S. 419 (1995); United States v. Bagley, 473 U.S. 667 (1985); United States v. Agurs, 427 U.S. 97 (1976); Giglio v. United States, 405 U.S. 150 (1972); Brady v. Maryland, 373 U.S. 83 (1963); en las leyes federales, ver, por ejemplo, 18 U.S.C. $\$ 3500$ (1970), en las Reglas Federales de Procedimiento Penal, ver, por ejemplo, Fed. R. Crim. p. 12.1, 12.2, 16, y 26.2; y en los poderes de supervisión de los tribunales.

77 Sobre la preparación de los testigos que realizan los abogados en Estados Unidos, ver, por ejemplo, Pizzi, W. T., Trials without truth: why our system of criminal trials has become an expensive failure and what we need to do to rebuild it, NYU Press, 2000, pp. 21-22 (1999). Ver no obstante, Federal Rules of Evidence 614(a) (estableciendo que el tribunal puede convocar de oficio a un testigo); Federal Rules of Evidence 706(a) (sosteniendo que el tribunal también puede designar a un perito de su propia selección). No obstante ello, estas potestades rara vez son utilizadas en los juicios penales. Ver, por ejemplo, United States v. Ostrer, 422 F. Supp. 93 (S.D.N.Y. 1976) (señalando que aunque el tribunal tenga la facultad discrecional de citar a un testigo de oficio, este poder rara vez es ejercido). Para un análisis de los obstáculos que enfrentarían los jueces si se volvieran más activos en el juicio, ver Frankel, M. E., "The search for truth: An umpireal view", University of Pennsylvania Law Review 123.5 (1975): 1031-1059. 
De los trasplantes legales a las traducciones legales: la globalización del plea...

torio, así como también redirecto ${ }^{78}$. Los plea bargainings también pueden ser explicados a través del modelo de la disputa porque es natural que en cualquier litigio las partes puedan negociar la solución ${ }^{79}$.

En el modelo de la investigación oficial, que se corresponde con el sistema inquisitivo, el proceso penal es conceptualizado como una pesquisa realizada por uno o más funcionarios públicos a fin de determinar si se cometió un delito y si el imputado participó en él ${ }^{80}$. Hay numerosos elementos del proceso penal de los países continentales europeos y latinoamericanos que se pueden explicar a través de este modelo ${ }^{81}$. La persecución penal obligatoria es necesaria en este modelo porque los procesos constituyen una investigación para establecer la verdad, y por lo tanto, sólo se puede desestimar el caso cuando no exista prueba de que se cometió un delito o que el imputado participó en él ${ }^{82}$. En este modelo no existe el

${ }^{78}$ Ver, por ejemplo, Fed. R. Evid. 611. La Regla de Prueba Federal 614(b) establece que "el tribunal podrá interrogar a los testigos, sean que hayan sido propuestos por el tribunal o por una de las partes". Pero el uso de esta potestad también es muy infrecuente en los juicios penales. Ver Bradley, supra nota 43, p. 421.

79 Ver, por ejemplo, Brady, 397 U.S. 742 (aprueba, por primera vez, la constitucionalidad del plea bargaining). Sobre la historia del plea bargaining en Estados Unidos, ver las referencias en la nota 55.

${ }^{80}$ Por ejemplo, respecto a que en Francia el fin del proceso penal es la determinación de la verdad, ver Rassat, M. L., Traité de procédure pénale, Presses universitaires de France, 2001, p. 297

${ }^{81}$ Recuérdese que esta descripción se refiere a los procesos penales de Argentina, Francia, Alemania e Italia, tal como eran antes de las reformas que analizaré en este artículo. Esto es particularmente importante en el caso de Italia, que cambió muchas de estas características cuando se movió en la dirección del modelo de la disputa con la introducción de su Código Procesal Penal de 1989. Sin embargo, y aun cuando esta descripción se refiera a los procesos penales anteriores a sus reformas, lo cierto es que muchas de estas características siguen estando presentes hoy en día en estos países. Cuando hago citas de reglas me estoy refiriendo a reglas que todavía hoy son válidas (refiriéndose al tiempo en que este artículo fue inicialmente publicado en el 2004).

82 Existen diferencias en la forma en que las cuatro principales jurisdicciones continentales europeas y latinoamericanas que se discuten en este artículo regulan esta cuestión. Para las jurisdicciones que establecen reglas de persecución penal obligatoria, ver Código Penal de Argentina, art. 59.4; Costituzione della Repubblica Italiana art. 112 (Italia). Alemania establece la obligatoriedad de la persecución penal como regla, aunque hay excepciones a través de su principio de oportunidad, $\$ \$ 152-54^{\text {a }}$, StPO [ley de procedimiento penal]. En Francia, el fiscal tiene discrecionalidad inicialment para decidir si requiere la instrucción. Code de procédure pénale art. 40. Pero si el fiscal francés decide requerir el inicio de la instrucción luego no puede 
concepto de la declaración de culpabilidad porque si bien la admisión de responsabilidad por parte del imputado puede ser un elemento de prueba muy importante, no provee necesariamente de una versión completa de la verdad, la cual debe ser determinada por el tribunal ${ }^{83}$. Además, no hay plea bargains ${ }^{84}$ no sólo porque no hay declaraciones de culpabilidad, sino también porque la verdad no puede ser negociada o arreglada. Finalmente, todo el proceso es estructurado y entendido como una investigación unitaria $^{85}$. Así, existe una sola investigación preliminar: la oficial ${ }^{86}$. En el juicio no hay un caso de la fiscalía y de la defensa, sólo el caso del tribunal, el tribunal decide en qué orden se presentan las pruebas en el debate ${ }^{87}$, los testigos y peritos no corresponden a las partes sino al tribunal ${ }^{88}$, y los interrogatorios son iniciados y dirigidos por el tribunal y no por las partes ${ }^{89}$.

desestimar el caso sin el consentimiento del tribunal. Ver Rassat, op. cit., pp. 452-53 (no analizaré aquí las facultades de la víctima con respecto a esta cuestión). Como no existe ningún sistema capaz de perseguir todos los delitos, la regla de la persecución penal obligatoria, o la discrecionalidad limitada, ha sido descripta como un mito. Se puede consultar el debate sobre este tema en los Estados Unidos en Goldstein, Abraham S. and Martin, M., "The myth of judicial supervision in three inquisitorial” systems: France, Italy, and Germany.", The Yale Law Journal 87, 2, 1977, pp. 240-283; Langbein, J. H. and Weinreb, L. L., "Continental Criminal Procedure: Myth and Reality”, Yale Law Journal, vol. 87, 1978, p. 1549.

${ }^{83}$ Ver Moskovitz, M., op. cit., p. 1153. Ver también Langbein, J.H., Criminal Procedure, op. cit., p. 73-74.

${ }^{84}$ Ver, por ejemplo, Langbein, J.H., Criminal Procedure, op. cit.

${ }^{85}$ Respecto a Francia, ver, por ejemplo, Dervieux, op. cit., p. 250.

${ }^{86}$ Ver id.

87 Ver por ejemplo, Código Procesal Penal de la Nación, art. 356 (Arg.). Respecto a Alemania, ver $\$ \$ 155$ Nr. 2, 244 Nr. 2 StPO. Ver también Roxin,C., Strafverfahrensrecht, op. cit. \$15, p. 95.

${ }^{88}$ Francia es una excepción porque durante el juicio los testigos son de las partes. Ver, por ejemplo, Rassat, op. cit., pp. 405-06. Sin embargo, no se puede preparar a los testigos, y sigue siendo el presidente del tribunal quien hace las preguntas de oficio o a pedido de las partes. Ver Código Procesal Penal (Francia) arts. 312, 332, 454, 536. Desde el $1^{\circ}$ de enero de 2001 también las partes pueden preguntar directamente a los testigos. Ver Dervieux, V., op. cit., pp. 258- 59.

${ }^{89}$ Respecto a Argentina, ver Código Procesal Penal (Francia) art. 389. Con relación a Alemania, ver $\$ \$ 238$ Nr. 1, 240 STPO (Ley procesal penal alemana). La sección 239 del StPO dice que los interrogatorios en el juicio deben desarrollarse a través del examen directo y del contrainterrogatorio (crossexamination), si la fiscalía y la defensa lo solicitan. Sin embargo, es muy raro que ello ocurra. Ver Roxin, C., op. cit., \$42, p. 343. 
De los trasplantes legales a las traducciones legales: la globalización del plea...

Las relaciones entre los actores del proceso en estos dos modelos pueden ser representadas esquemáticamente de la siguiente manera:

\section{Modelo de la Disputa}

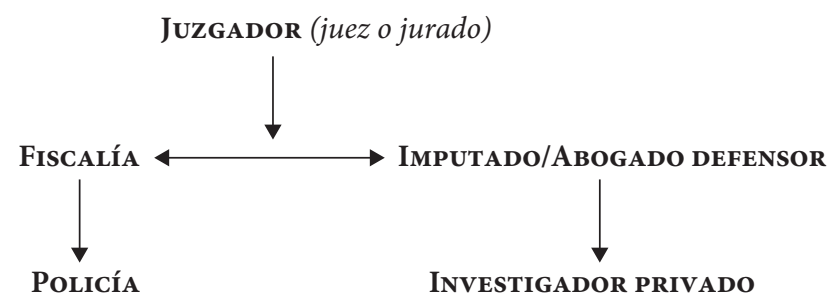

Modelo de LA InVESTigación Oficial

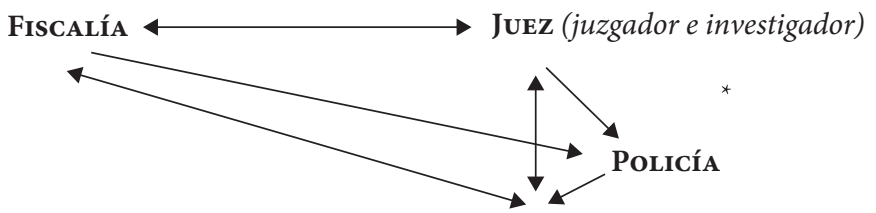

IMPUTADO/ABOGADO DEFENSOR

* En las jurisdicciones continentales europeas y latinoamericanas la policía trabaja bajo la supervisión de la fiscalía o del juez -generalmente dependiendo de quién está a cargo de la investigación preliminar-, o ambos.

En el modelo de la disputa, la fiscalía y la defensa se encuentran en el mismo nivel, tanto en lo que se refiere a que tienen relativamente las mismas potestades procesales, como a que ambos son considerados como partes que tienen un interés en juego en el caso ${ }^{90}$. Cada uno tiene sus propios

${ }^{90}$ Por lo general, se dice que en Estados Unidos el rol del fiscal no sólo es obtener una condena, sino también una decisión justa. Pero en términos comparativos los fiscales estadounidenses habitualmente actúan como partes con un interés en juego en el caso. Por ejemplo, 
investigadores - la policía en el caso de la fiscalía, un investigador privado en el caso de la defensa-. El órgano decisor se encuentra por encima de ambos, pero sólo puede tomar decisiones sobre el caso en la medida en que ambas partes consideren que existe una disputa.

También hay un fiscal en el modelo de la investigación oficial. Pero este fiscal no es visto como una parte, sino, más bien, como otro funcionario público o magistrado cuyo rol es establecer la verdad ${ }^{91}$. Existe una suerte de división de tareas entre el fiscal y el juez: el primero requiere la investigación de los hechos, la producción de la prueba y la aplicación del derecho, mientras que el segundo investiga, produce la prueba y aplica el derecho. Pero ambos son esencialmente lo mismo: funcionarios públicos imparciales cuya tarea es investigar la verdad ${ }^{92}$. En el esquema provisto se representa al imputado debajo del juez y del fiscal pero no porque no tenga derechos, sino porque tiene un interés en juego en la resolución del caso, y porque no sólo es un sujeto de derechos sino, además, un objeto de investigación ${ }^{93}$. No hay ningún investigador privado para la defensa puesto

consideran que ganan un caso cuando el acusado es condenado y que lo pierden cuando es absuelto o se dicta un sobreseimiento. Ver Pizzi, W. T., op. cit., p. 1349.

${ }^{91}$ Ver Weigend, W., op. cit., pp. 1233-34.

92 Ver id.

${ }^{93}$ Muchos autores han dicho que en el sistema acusatorio el imputado es un sujeto de derechos, mientras que en el sistema inquisitivo es un objeto de investigación. Posiblemente esto haya sido cierto durante mucho tiempo, pero después de la Segunda Guerra Mundial -e incluso antes en algunas jurisdicciones- la mayoría de los países inquisitivos comenzaron a considerar al imputado como un sujeto de derecho, tanto en el nivel normativo -constituciones, tratados sobre derechos humanos, códigos procesales penales- como en el nivel de la práctica del derecho. Por ende, en la mayoría de las jurisdicciones continentales europeas y latinoamericanas hoy en día se presume que el imputado es inocente hasta que haya una condena, se reconoce la garantía contra la auto-incriminación forzada, el derecho a contar con un abogado, etc. Ver, por ejemplo, Van Kessel, G., "European perspectives on the accused as a source of testimonial evidence", West Virginia Law Review, 100, 1997, p. 799. Esto no significa, por supuesto, que todos los derechos enunciados sean respetados en la práctica. Lo que pretendo señalar es que el concepto "derechos" parace haber perdido parte de su antiguo valor heurístico para establecer distinciones claras entre los sistemas acusatorios e inquisitivos. Por este motivo no lo menciono como una de las diferencias entre los dos sistemas, tanto en la oposición entre el modelo de la disputa y el de la investigación oficial, como en la oposición entre los modelos de la coordinación y de la jerarquía. Del mismo modo, los conceptos de persecución pública vs. privada tenían un valor heurístico en el pasado en parte porque las jurisdicciones anglosajonas desarro- 
De los trasplantes legales a las traducciones legales: la globalización del plea...

que existe una sola investigación oficial, aquella que lleva a cabo el juez, el fiscal y la policía. Si la defensa pretende que se produzca determinada prueba debe requerirla al fiscal o al juez ${ }^{94}$.

El segundo par de modelos que utilizo para captar las diferencias entre los procesos penales del common law y de las jurisdicciones continentales europeas y latinoamericanas lo constituyen los modelos de la coordinación y de la jerarquía en la terminología del profesor Damaška ${ }^{95}$. Según este autor, en el modelo de la coordinación la autoridad la ejercen órganos decisores legos que se encuentran en relaciones de poder relativamente horizontales entre ellos, y que aplican en sus decisiones estándares comunitarios ${ }^{96}$. En el modelo de la jerarquía, la autoridad la ejercen órganos decisores profesionales cuyas relaciones son jerárquicas y que aplican en sus decisiones reglas técnicas ${ }^{97}$.

Aquí utilizo estos modelos con ligeras modificaciones. En el modelo de la coordinación, característico del proceso acusatorio, incluyo la participación popular mediante el jurado ${ }^{98}$, menos controles jerárquicos ${ }^{99}$, una preferencia por la producción oral de la prueba en el juicio ${ }^{100}$, un tribunal bifurcado compuesto por un órgano lego (jurado) y uno profesional (juez), la inexistencia de reglas que obligan a fundamentar el veredicto ${ }^{101}$, y la existencia de reglas probatorias detalladas que filtran los elementos de prueba que se admiten en el juicio y que guían la valoración de la prueba

llaron un sistema de persecución pública mucho más recientemente que las jurisdicciones continentales europeas y latinoamericanas. Hoy en día esa distinción ya no tiene un valor heurístico en términos comparativos. Con respecto a la influencia holandesa en el desarrollo de la fiscalía o perseguidor público en los Estados Unidos, ver Reiss, A. J., "Public prosecutors and criminal prosecution in the United States of America", Jurid. Rev. 1975, p. 1. Respecto a la influencia francesa sobre el mismo desarrollo, ver Fournier, A., Code de Procédure Criminelle De L'État de New York, 1893, p. 9.

94 Ver, por ejemplo, Dervieux, V., op. cit., p. 250.

${ }^{95}$ Ver Damaška, M., Faces of Justice, op. cit., pp. 16-71.

${ }^{96}$ Id. p. 17.

97 Id.

98 Constitución EE.UU., enmienda VI; Duncan v. Louisiana, 391 U.S. 145 (1968).

99 Ver Kepner v. United States, 195 U.S. 100 (1904) (sosteniendo que la fiscalía no puede recurrir las absoluciones en Estados Unidos).

${ }^{100}$ Ver, por ejemplo, Federal Rules of Criminal Procedure 26, y Federal Rules of Evidence 802.

${ }^{101}$ Ver Federal Rules of Criminal Procedure p. 31. 
que, finalmente, es introducida ${ }^{102}$. En el modelo de la jerarquía - parte del proceso inquisitivo - incluyo órganos decisores profesionales ${ }^{103}$, un mayor control jerárquico ${ }^{104}$, la aceptación de los elementos de prueba recolectados durante la investigación preliminar y documentada en el expediente ${ }^{105}$, un

${ }^{102}$ Ver, por ejemplo, Federal Rules of Evidence.

${ }^{103}$ La provincia de Córdoba en Argentina, Francia, Alemania e Italia tienen tribunales mixtos compuestos por jueces profesionales y legos - para juzgar los casos penales más graves. Pero en estos tribunales mixtos los jueces profesionales siguen siendo los más influyentes debido a su conocimiento legal y experiencia, y porque los jueces profesionales y legos deliberan juntos. Para un análisis de los tribunales mixtos, ver Langbein, J. H., "Mixed Court and Jury Court: Could the Continental Alternative Fill the American Need?", American Bar Foundation Research Journal, 6.1, 1981, pp. 195-219. Un número importante de sistemas inquisitivos de Europa continental intentaron importar el juicio por jurados durante el siglo XIX. El precursor fue Francia, que estableció el jurado dos veces, en 1791 y 1808. Otros países, como Alemania, siguieron su ejemplo. Sin embargo, hoy en día la mayoría de los sistemas inquisitivos han reemplazado al jurado con tribunales mixtos, o directamente no tienen ningún tipo de participación popular en el sistema de justicia penal (como mencionaré más adelante, dos excepciones son Rusia y España, que introdujeron el jurado en sus respectivos sistemas en 1993 y 1995). Se pueden consultar descripciones sobre la introducción del jurado en Francia y Alemania durante el siglo XIX en los artículos incluídos en Schioppa, P. A., (Ed.), The Trial Jury in England, France, Germany, 1700-1900, Berlín, Duncker und Humbolt, 1987, pp. 1700-1900. Para una explicación de por qué Francia y Alemania finalmente rechazaron esta institución y adoptaron tribunales mixtos, ver Kahn-Freund, O., "On Uses and Misuses of Comparative Law”, en Selected Writings, 1978, pp. 294, 310. Para un análisis del giro en contra del juicio por jurados por parte de actores legales conservadores y liberales luego del 1900 aproximadamente, ver. Hett, B. C., Death in Tiergarten and Other Stories: Murder and Criminal Justice in Berlin, 1891-1933, pp. 343-45 (tesis doctoral no publicada, Harvard University, disponible en el archivo de Harvard International Law Journal, 2001). Para un análisis de la historia del jurado en Alemania y su vínculo con debates actuales de filosofía política, ver Dubber, M. D., "The German Jury and the Metaphysical Volk: From Romantic Idealism to Nazi Ideology", American Journal of Comparative Law, 43, 1995, p. 227.

${ }^{104}$ Ver, por ejemplo, Langbein, J. H., Comparative criminal procedure, op. cit., pp. 84-85.

${ }^{105}$ Las jurisdicciones continentales europeas y latinoamericanas actuales se basan en la producción oral de la prueba mucho más que en el pasado. Por ejemplo, su principio de inmediación establece que el órgano decisor, el acusador y la defensa, deban estar presentes durante la producción de la prueba que será valorada por el tribunal para emitir su sentencia. Ver, por ejemplo, Maier, J.B.J., op. cit., Derecho Procesal Penal, $₫ 8(D)(3)(c)$, pp. 877-78. Sin embargo, los elementos de prueba colectados en el expediente siguen teniendo influencia sobre los jueces del debate -que en la mayoría de las jurisdicciones no participan del procedimiento preliminar y sólo conocen estos elementos a partir de los registros escritos-. Para un análisis de esta cuestión en Alemania, ver Damaška, M., "Of hearsay and its analogues", Minnesota Law Review 76, 1992, pp. 425, 449-52. 
De los trasplantes legales a las traducciones legales: la globalización del plea...

tribunal unitario que decide qué prueba se admite en el juicio y que luego la valora en la sentencia ${ }^{106}$, la justificación escrita de esa sentencia ${ }^{107}$, y pocas reglas que filtran los elementos de prueba que son admitidos en el juicio y que establecen cómo deben ser valorados ${ }^{108}$. Obviamente que esta descripción del modelo de la jerarquía y de la coordinación es breve y esquemática. Sin embargo, no es necesaria una descripción más detallada de ambas categorías puesto que en este artículo hago un uso limitado de ellas ${ }^{109}$. Como se verá más adelante, las categorías fundamentales para analizar la transferencia del plea bargaining del sistema acusatorio al inquisitivo serán los modelos de la disputa y de la investigación oficial.

\section{Reformas recientes en el sistema inquisitivo y la tesis de la "americanización"}

Si la tesis de la "americanización" tiene algún tipo de relevancia, incluso en su forma débil, es necesario explicar con mayor precisión la influencia del sistema acusatorio sobre los sistemas continentales europeos y latinoamericanos. Esta sección describe estas influencias en el ámbito del proceso penal. En las últimas tres décadas, y según la región y la jurisdicción, un gran número de países de Europa continental y Latinoamérica introdujeron reformas acusatorias en sus sistemas procesales inquisitivos que van en la dirección del modelo de la disputa y del modelo de la coordinación ${ }^{110}$.

${ }^{106}$ Ver, por ejemplo, Código Procesal Penal de la Nación (Argentina) arts. 356, 398.

${ }^{107}$ Ver, por ejemplo, Constitución, art. 111.6 (que estaba vigente incluso antes de la reforma de noviembre de 1999).

${ }^{108}$ Ver, por ejemplo, Merle, Roger-Vitu, Andre ,Traité de droit criminel, 5éme édition, París, 2001.

${ }^{109}$ Ver infra secciones IV y VIII.

${ }^{110}$ En los últimos treinta años ha habido una tendencia por parte de la academia legal anglosajona a proponer reformas inspiradas en la tradición continental europea y latinoamericana. Sin embargo, y a pesar de la calidad de estos trabajos y del hecho de que fueron escritos por distinguidos autores, lo cierto es que ha sido una tendencia muy marginal en el sistema de justicia penal estadounidense y no se ha plasmado en reformas concretas. Entre los trabajos académicos que se han inspirado en el proceso penal continental europeo y latinoamericano se pueden ver Davis, K. C., op. cit., pp. 191-95; Kagan, R., Adversarial legalism, pp. 86-87; Spencer, J.R.S., "French and English Criminal Procedure”, en Markesinis, Basil, ed. 
En su avance hacia el modelo de la disputa, varios países continentales europeos y latinoamericanos han intentado transformar al juez en un actor más pasivo, con lo cual se depende cada vez más de la fiscalía y la defensa para determinar los hechos y conducir el proceso. Por ejemplo, varios de estos países eliminaron la figura del juez de instrucción ${ }^{111}$ - un símbolo del proceso inquisitivo - e intentaron reemplazarlo por una investigación preliminar conducida por la fiscalía y, en algunos casos, la defensa ${ }^{112}$. Durante la etapa preparatoria el rol del juez se limita a dictar órdenes de requisa y secuestro, e imponer arrestos, prisión preventiva y cauciones, de un modo

The Gradual convergence: foreign ideas, foreign influences, and English law on the eve of the 21st century, Clarendon Press, 1994, pp. 33-45; Pizzi, W.T., op. cit.; Weinreb, L. L., Denial of Justice: Criminal Process in the United States, New York: Free Press, 1977; Alschuler, A. W., "Implementing the Criminal Defendant's Right to Trial: Alternatives to the Plea Bargaining System”, University of Chicago Law Review, vol. 50, 1983, p. 931; Dubber, M. D., "American Plea Bargains, German Lay Judges, and the Crisis of Criminal Procedure", en Stanford Law Review, vol. 49, 1997, p. 547; Frase, R. S., "Comparative Criminal Justice as a Guide to American Law Reform: How Do the French Do It, How Can We Find Out, and Why Should We Care?", California Law Review, vol. 78, p. 539 (1990); Frase, R. S. and Weigend, T., "German criminal justice as a guide to American law reform: Similar problems, better solutions", Boston College International and Comparative Law Review, vol. 18, 1995, p. 317; Krug, p., op. cit., 73; Langbein, J. H., "Land Without Plea Bargaining: How the Germans Do It", op. cit.; Langbein, J. H., "Mixed Court and Jury Court: Could the Continental Alternative Fill the American Need?”, op. cit.; Van Kessel, G., "Adversary Excesses in the American Criminal Trial”, Notre Dame Law Review, vol. 67, 1992, p. 403. Para un análisis de por qué en los últimos años no han habido reformas en el sistema acusatorio estadounidense inspiradas en el sistema inquisitivo, ver Langbein, J. H., "The Influence of Comparative Procedure in the United States", American Journal of Comparative Law, vol. 43, 1995, p. 545; Langbein, J. H., "The Influence of the German Emigrés on American Law: The Curious Case of Civil and Criminal Procedure", en Lutter, Marcus, Stiefel, Ernst y Hoeflich, Michael H (eds.) Der Einfluss deutscher Emigranten auf die Rechtsentwicklung in den USA und in Deutschland: Vorträge und Referate des Bonner Symposions im September 1991, Mohr Siebeck, 1993, p. 321.

${ }^{111}$ Esta figura es conocida como Juge d'Instruction en Francia, Untersuchungsrichter en Alemania, Giudice Istruttore en Italia y Juez de Instrucción en América Latina.

${ }^{112}$ Por ejemplo, Costa Rica puso al fiscal a cargo de la investigación preliminar, ver Código Procesal Penal de Costa Rica, arts. 290-91. Sin embargo, la defensa no realiza su propia investigación. Si pretende que determinados elementos de prueba sean colectados durante la etapa preliminar, debe solicitarlo a la fiscalía, ver Código Procesal Penal, art. 292 (Costa Rica). Pero en el nuevo código procesal de Italia, en donde la fiscalía está a cargo de la investigación preliminar, la defensa puede colectar sus propios elementos de prueba durante esta etapa, ver infra notas 164 y 225. 
De los trasplantes legales a las traducciones legales: la globalización del plea...

parecido al modelo anglosajón. Alemania $(1975)^{113}$, Italia (1989) ${ }^{114}$, Guatemala $(1994)^{115}$, y las provincias de Buenos Aires y Córdoba en Argentina $(1998)^{116}$, Costa Rica $(1998)^{117}$, Venezuela $(1999)^{118}$ y Chile $(2000-2003)^{119}$, entre otros, han avanzado en esta dirección.

Además, varias jurisdicciones también han modificado los roles relativos de la fiscalía y la defensa durante el juicio. Por ejemplo, Italia introdujo el examen directo y cruzado de testigos en el juicio ${ }^{120}$ y ha permitido que tanto la fiscalía como la defensa citen a sus testigos ${ }^{121}$. Italia también ha estructurado sus juicios de modo tal que se dividen en un caso de la fiscalía y uno de la defensa, al igual que en el sistema acusatorio de los Estados Unidos ${ }^{122}$. Los países continentales europeos y latinoamericanos también han comenzado a eliminar, o atenuar, la regla de la persecución penal obligatoria o principio de legalidad, otra característica típica del sistema inquisitivo; ejemplos de ello incluyen a Guatemala $(1994)^{123}$, Costa Rica (1998) ${ }^{124}$ y Chile (2000-2003) ${ }^{125}$.

${ }^{113}$ Ver Roxin, C., Strafverfahrensrecht, op. cit. $\$ 72$, p. 533.

${ }^{114}$ Ver, por ejemplo, Vassalli, G., "Premessa", en Istituto poligrafico e zeca dello Stato. Progetto Preliminare del Codice di Procedura Penale, 1988, pp. 5, 6- 7; Amodio, Ennio \& Selvaggi, E., "An Accusatorial System in a Civil Law Country: The 1988 Italian Code of Criminal Procedure", Temple Law Review, vol. 62, 1989, pp. 1211, 1218-19.

${ }^{115}$ Ver Ramírez, L. R. G. y Urbina, M. A.G. en Ambos, K., Maier, J. et al. Las reformas procesales penales en América Latina, AD-HOC, 2000, pp. 443, 458-59, 471-72 [en adelante Las Reformas]

${ }^{116}$ Ver Fabricio Guariglia \& Eduardo Bertoni, Argentina, en Las Reformas, op. cit., pp. 35, 53-54.

${ }^{117}$ Ver Daniel González Álvarez, Costa Rica, en Las Reformas, op. cit., pp. 69, 287-88.

${ }^{118}$ Ver Sergio Brown Cellino, Venezuela, en Las Reformas, op. cit., pp. 769, 803.

${ }^{119}$ Sobre las dificultades para introducir estas clases de reformas en una jurisdicción inquisitiva como Chile, ver de la Barra Cousino, C.R., "Adversarial vs. Inquisitorial Systems: The Rule of Law and Prospects for Criminal Procedure Reform in Chile", en Southwestern Journal of Law and Trade in the Americas., 1998, vol. 5, p. 323.

${ }^{120} \mathrm{CPP}$ art. 498 (Italia).

${ }^{121} \mathrm{Id}$.

${ }^{122}$ Id. arts. 493, 498.

${ }^{123}$ Código Procesal Penal, art. 25 (Guatemala).

${ }^{124}$ Código Procesal Penal., art. 22 (Costa Rica).

${ }^{125}$ Código Procesal Penal, art. 170 (Chile). 
A los fines de esta investigación es importante señalar que varios países han introducido mecanismos consensuales inspirados en el plea bargaining, incluyendo a Alemania (durante la década de los setenta ), Italia (1989), Guatemala (1994) ${ }^{126}$, Argentina (1998), Costa Rica (1998) ${ }^{127}$ y Francia (1998).

También han habido movimientos importantes hacia el ideal de la coordinación. Así, algunos países han introducido al jurado en su proceso penal, como Rusia (1993) ${ }^{128}$ y España (1995) ${ }^{129}$. Asimismo, numerosas jurisdicciones continentales europeas y latinoamericanas intentaron introducir mayores técnicas orales de manejo de los casos propias del modelo de la coordinación y reducir la importancia tradicional del expediente escrito en el sistema inquisitivo. Ejemplos de ello lo constituyen Italia (1989) ${ }^{130}$, Argentina (sistema federal, 1992) ${ }^{131}$, Guatemala (1994) ${ }^{132}$, la provincia de Buenos Aires en Argentina (1998), Paraguay (1999) ${ }^{133}$, Venezuela (1999) ${ }^{134}$ y Chile (2000-2003) ${ }^{135}$.

Tanto con respecto al modelo de la disputa como al modelo de la coordinación, las recientes reformas en las jurisdicciones continentales euro-

${ }^{126}$ Para un análisis de este mecanismo en Guatemala, ver Bovino, A., Temas de derecho procesal penal guatemalteco. No. 343.1 (728.1), Fundación Myrna Mack, 1996, pp. 141-64.

${ }^{127}$ Código Procesal Penal, arts. 373-75 (Costa Rica).

${ }^{128}$ Ver Gildin, G. S., "Trial by Jury in the New Russia: A Travelogue”, Dick Journal of International Law, vol. 15, 1996, p. 151; Plotkin, S. R., "The Jury Trial in Russia”, Tulane Journal of International and Comparative Law, vol. 2, 1994, p. 1; Thaman, S. C., "The Resurrection of Trial by Jury in Russia", Stanford Journal of International Law, vol. 31, 1995, p. 61. Ver también Orland, L., "A Russian Legal Revolution: The 2002 Criminal Procedure Code", Conneticut Journal of International Law, vol. 18, 2002, p. 133 (en donde se indica que el nuevo Código Procesal Penal de Rusia de julio de 2002 también incluye el juicio por jurado para los casos más graves).

${ }^{129}$ Ver Gleadow, C., History of trial by jury in the Spanish legal system, No. 6, Edwin Mellen Pr, 2000, pp. 245-85; Thaman, S. C., "Spain Returns to Trial by Jury" Hastings International and Comparative Law Review, vol. 21, 1998, p. 241. Ver también Thaman, S. C., "Europe’s New Jury Systems: The Cases of Spain and Russia Law and Contemporary Problems, vol. 62,1999, p. 233.

${ }^{130}$ Ver, por ejemplo, Grande, op. cit., pp. 237-39, 257.

${ }^{131}$ Ver, por ejemplo, Guariglia \& Bertoni,V, op. cit., pp. 64-65.

${ }^{132}$ Ver Ramírez García \& Urbina, op. cit., pp. 480-81.

${ }^{133}$ Ver, por ejemplo, Alfredo Enrique Kronawetter, Paraguay, en Las Reformas, op. cit., p. 605, 635-36.

${ }^{134}$ Ver, por ejemplo, Brown Cellino, op. cit., pp. 806-07.

${ }^{135}$ Ver, por ejemplo, Riego, Chile, en Las Reformas, op. cit., p. 167, 179. 
De los trasplantes legales a las traducciones legales: la globalización del plea...

peas y latinoamericanas parecen confirmar la versión débil de la tesis de la "americanización" en el proceso penal. Sin embargo, no necesariamente confirman la versión fuerte de la tesis de la "americanización” que sostiene que las culturas y prácticas legales de las jurisdicciones influenciadas eventualmente van a parecerse o imitar a sus homólogos estadounidenses. Una valoración rigurosa de la tesis fuerte exige un estudio más detallado de cómo las ideas legales, reglas e instituciones viajan o circulan entre los sistemas legales, así como también los tipos de transformaciones que ocurren durante este proceso. En otras palabras, además de estudiar e identificar las influencias del sistema estadounidense, es necesario entender cómo estas influencias han sido traducidas y qué clase de interacciones han ocurrido entre estas reformas y las prácticas preexistentes de los sistemas de justicia penales receptores.

\section{La circulación de ideas legales: de los trasplantes legales a las traducciones legales}

Hasta ahora la metáfora de los trasplantes legales - popularizada por Alan Watson - ha sido la metáfora dominante en el análisis de la circulación de instituciones legales entre sistemas legales ${ }^{136}$. A través de numerosos libros y artículos, Watson ha demostrado que la transferencia, el préstamo y la imposición de reglas legales han sido comunes desde tiempos inmemorables, y ha utilizado la metáfora del trasplante para explicar esos sucesos ${ }^{137}$.

${ }^{136}$ Ver, por ejemplo, Watson, Alan. Evolution of Law. Johns Hopkins University Press, 1985; Watson, Legal Transplants: an Approach to Comparative Law, op. cit.; Watson, A., Society And Legal Change 2Nd Ed. Temple University Press, 1977; Watson, A., "Aspects of Reception of Law", American Journal of Comparative Law, vol. 44, 1995, p. 335.

${ }^{137}$ El trabajo de Watson debería ser leído parcialmente como una intervención en los debates sobre la autonomía del derecho. En sus análisis históricos Watson intentó demostrar que el derecho no es un espejo de la cultura social, de la sociedad o de la economía, sino que el derecho cambia como consecuencia de sus desarrollos internos en los cuales el trasplante de las reglas legales tiene un rol central. En este sentido, Watson intenta cuestionar los análisis culturales a là Montesquieu, los del marxismo y los "derecho y sociedad" contemporáneos. Para valoraciones críticas sobre la intervención de Watson en estos debates, ver Abel, R. L., "Law as Lag: Inertia as a Social Theory of Law", Michigan Law Review, vol. 80, 1982, p. 785; 
El éxito de su propuesta es atribuible a numerosas causas, y muchos autores de diferentes ramas del derecho la han adoptado ${ }^{138}$. No obstante, en esta sección cuestiono que la metáfora sea adecuada para discutir la circulación de instituciones legales y, en su lugar, propongo el modelo de la traducción legal como una nueva herramienta heurística para interpretar estas cuestiones.

Hay varios motivos que explican el éxito de la metáfora del trasplante. Primero, el aumento sustancial de la circulación de ideas e instituciones legales a causa de la globalización ${ }^{139}$ ha creado una necesidad e interés en los modos de conceptualizar este fenómeno; la popularidad de la metáfora del trasplante se debe, en parte, a la necesidad de llenar el vacío entre la teoría y la práctica. Segundo, la metáfora del trasplante es poderosa por su naturaleza inherentemente comparativa: el trasplante, como metáfora médica o botánica, supone un cuerpo o ambiente originario y uno receptor. De esta manera, la metáfora permite la comparación tanto entre los sistemas legales originarios y receptores, así como entre las reglas, ideas e instituciones legales originarias y trasplantadas. Esta interpretación puede

Ewald, W., "The American Revolution and the Evolution of Law", en American Journal of Comparative Law, vol. 42, 1994, p. 1; Ewald, W. "Comparative Jurisprudence (II): The Logic of Legal Transplants", American Journal of Comparative Law vol. 43, 1995, p. 489.

${ }^{138}$ Ver, por ejemplo, Ajani, op. cit..; Berkowitz et al., op.cit.t., p. 5; Buscaglia y Rafliff, op. cit.; Ugo Mattei, op. cit. p. 22; Schauer, F., op. cit. p. 22.

${ }^{139}$ Ver, por ejemplo, Friedman, L., "Erewhon: The Coming Global Legal Order", Stanford Journal of International Law, vol. 37, 2001, p. 347. La globalización también ha sido caracterizada por el aumento de la circulación de bienes y servicios, así como de información. Ver generalmente Sassen, S., Globalization and Its Discontents. Essays on the new mobility of people and money.,New York, 1998. Para introducciones generales sobre los debates sobre la globalización, ver, por ejemplo, Holden, B., ed. The ethical dimensions of global change, Springer, 1996; Featherstone, Mike, ed. Global culture: Nationalism, globalization and modernity. Vol. 2. Sage, 1990; Holden, Barry, ed. Global democracy: Key debates. Routledge, 2000; McGrew, A. G., and Held, D. (eds.), The global transformations reader: an introduction to the globalization debate, Polity Press, 2000; Lechner, F. J., and Boli, J. (eds.), The globalization reader, John Wiley \& Sons, 2000; Jenson, J. and Boaventura de Sousa Santos, (eds.), Globalizing institutions: Case studies in regulation and innovation, Routledge, 2000. Sobre los efectos potenciales de las tendencias globalizadoras en la relación entre la soberanía del Estado y el derecho internacional, ver Raustiala, K., "The Architecture of International Cooperation: Transgovernmental Networks and the Future of International Law", Virginia Journal of International Law, 2002, vol. 43, p. 1. 
De los trasplantes legales a las traducciones legales: la globalización del plea...

ser particularmente interesante para el derecho comparado, y una forma útil de analizar el fenómeno de las influencias legales culturales - como la "americanización" - y otras tesis sobre la globalización del derecho (como la tesis de la convergencia) ${ }^{140}$. Finalmente, la idea del trasplante también es poderosa porque, debido a su naturaleza médica y botánica, incluye la necesidad de adaptación de la regla legal transferida al nuevo organismo o ambiente - las prácticas del sistema legal existente- $y$, al mismo tiempo, la posibilidad de rechazo por parte del organismo o ambiente receptor -el sistema legal receptor- ${ }^{141}$.

Pese a ello, la metáfora del trasplante legal presenta varias deficiencias. En primer lugar, no logra explicar la posibilidad de que, en muchos casos, los conceptos y prácticas legales se transfieren a ciertos niveles conceptuales pero no otros. Por ejemplo, el control de constitucionalidad es una idea y mecanismo que fue "trasplantado" de los Estados Unidos a la Europa continental ${ }^{142}$. Sin embargo, el sistema de revisión constitucional en la Europa continental presenta diferencias sustanciales con la versión estadounidense: (a) en los Estados Unidos todos los tribunales pueden declarar inconstitucional una ley o un acto de gobierno, mientras que en Europa continental generalmente puede hacerlo un tribunal constitucional centralizado; (b) en los Estados Unidos los tribunales que realizan este

${ }^{140}$ Ver Markesinis, B. (ed.) The Gradual convergence: foreign ideas, foreign influences, and English law on the eve of the 21st century, Clarendon Press, 1994; Legrand, P., "European Legal Systems Are Not Converging", International and Comparative Law Quaterly, vol. 45, 1996, p. 52. Para una discusión sobre la tesis de la convergencia en el proceso penal, ver por ejemplo, Amann, D. M., "Harmonic Convergence? Constitutional Criminal Procedure in an International Context", Indiana Law Journal vol. 75, 2000, p. 809; Bradley, C. M., "The convergence of the continental and the common law model of criminal procedure", Criminal Law Forum, Vol. 7, No. 2, Kluwer Academic Publishers, 1996. Reseña de Fennell, Phil, et al., eds. Criminal justice in Europe: a comparative study, Clarendon Press, 1995.

${ }^{141}$ No es de extrañar que el debate más interesante sobre los trasplantes legales durante la década de los setenta fue sobre el posible rechazo de las reglas o ideas legales trasplantadas. Comparar Kahn-Freund, O., "On uses and misuses of comparative law", Modern Law Review 37, 1974; Watson, A., "Legal Transplants and Law Reform”, Law Quaterly Review, vol. 92, 1976, p. 79.

${ }^{142}$ Ver Blankenburg, E., op. cit., supra nota 16. 
control de constitucionalidad son parte del poder judicial, mientras que en Europa continental no siempre es así1 ${ }^{143}$.

La metáfora del trasplante no es lo suficientemente flexible para captar estos matices y transmite la idea equivocada de que los mismos conceptos y prácticas de "control de constitucionalidad" existen en los Estados Unidos y en Europa continental. Un riñón o un olmo se van a ver esencialmente iguales en los cuerpos o ambientes originarios y en los receptores, pero ello no es lo que generalmente ocurre con las ideas e instituciones legales, que son imitadas a ciertos niveles conceptuales pero no otros.

Otro problema con la metáfora del trasplante es que incluso cuando los reformadores intentan imitar una idea o práctica legal de la manera más fidedigna posible, esta nueva idea, de todos modos, puede ser transformada por la(s) estructura(s) de sentido, las disposiciones individuales, los mecanismos y marcos institucionales y de poder, los sistemas de incentivos, etc., que se encuentren presentes en el sistema legal receptor ${ }^{144}$. Por ejemplo, y como se explicó anteriormente, los encargados de la reforma italiana quisieron importar un juicio acusatorio al introducir el principio de que el juez únicamente puede ordenar la producción de prueba en el juicio a solicitud de una de las partes ${ }^{145}$. Sin embargo, el código de procedimientos penal también prevé una excepción a este principio al permitir al tribunal

${ }^{143}$ Para un análisis del Consejo Constitucional de Francia, ver por ejemplo, Provine, D. M., "Courts in the Political Process in France", en Jacob, H., Blankenburg, E., Kritzer, H. M., Provine, D. M., \& Sanders, J., Courts, law, and politics in comparative perspective, Yale University Press, 1996, pp. 177, 190-193.

${ }^{144}$ Este es el motivo por el cual Pierre Legrand entiende que los trasplantes legales son imposibles. El sentido de una regla legal no es determinado - o no es sólo determinado - por las palabras que expresan la regla, sino por el resto del contexto del sentido - i.e., el sistema legal - en el cual la regla está situada. Por ende, cada vez que las palabras que expresan una regla legal son transferidas del sistema legal A, al sistema legal B, el sentido de estas palabras cambiará porque no existen dos sistemas legales exactamente iguales con respecto a sus contextos de sentido. La transformación de la regla transferida - y de ahí la imposibilidad del trasplante legal - será incluso mayor con la transferencia de un sistema del common law a uno continental europeo y latinoamericano o viceversa, de acuerdo con las profundas diferencias que tradicionalmente existen entre ambos sistemas legales. Ver Legrand, P., "The Impossibility of Legal Transplants" Maastricht Journal of European and Comparative Law, vol. 4, 1997, p. 111. 
De los trasplantes legales a las traducciones legales: la globalización del plea...

de juicio que produzca prueba de oficio si fuese absolutamente necesario $^{146}$. Si bien esta excepción no es inusual en las reglas procesales de los Estados Unidos ${ }^{147}$, lo cierto es que los jueces rara vez la ejercen ${ }^{148}$. Por el contrario, como en Italia un número importante de actores legales están acostumbrados al modelo inquisitivo (y por ende poseen un conjunto de disposiciones internas predominantemente inquisitivas), esta excepción ha sido interpretada de manera tal que le otorga al tribunal amplias potestades para ordenar nuevas pruebas ${ }^{149}$. El resultado parece ser un juicio que unas veces es interpretado a través del modelo de la disputa - tal como fue concebido originalmente por los reformistas- y otras a través del modelo de la investigación oficial ${ }^{150}$.

Según el marco teórico desarrollado en la sección II, no es sorprendente que esta transformación ocurra en un país como Italia, en donde claramente predominaba un sistema inquisitivo como estructura de interpretación de sentido, en las disposiciones individuales de la mayoría de los actores legales y en la distribución de poderes procesales. Sin embargo, aquí quiero enfatizar que la metáfora del trasplante parece ser, nuevamente, demasiado rígida para captar las transformaciones que ha sufrido el juicio estadounidense en Italia como consecuencia de la interacción con las prácticas judiciales penales preexistentes predominantemente inquisitivas.

Un tercer problema con la metáfora del trasplante es que la transferencia de las reglas, ideas y prácticas legales puede transformar profundamente tanto a la propia práctica transferida, como así también al sistema legal receptor en su totalidad. Así, en el ejemplo anterior, el juicio estadounidense ha sido transformado en su nuevo contexto italiano y, al mismo tiempo, también introdujo nuevos elementos de la disputa en el sistema ita-

\footnotetext{
${ }^{146}$ CPP art. 507. (2002) (Italia).

${ }^{147}$ Ver, por ejemplo, Federal Rules of Evidence 614(a).

${ }^{148}$ Ver United States v. Ostrer, 422 F. Supp. 93 (S.D.N.Y. 1976) (en donde se sostiene que aunque el tribunal tiene facultades discrecionales para convocar testigos, lo cierto es que rara vez se utiliza).

${ }^{149}$ Ver, por ejemplo, Corte costituzionale, 24 mar. 1993, n.111, Raccolta ufficiale delle sentenze e ordinanze delle Corte costituzionale, vol. 106, 1993, 733 (Azzari); Cass. Pen., sez. un., 28 dic. 1999, n.5549, (Paternò); Cass. Pen., sez. un. 6 nov. 1992, n.11227, (P.M. in proc. Martin), en Cassazione Penale 1993, vol. 33, 280, n.157; Grande, op. cit., p. 246 (con cita de más decisiones). ${ }^{150}$ Ver Grande, op. cit., pp. 246-47.
} 
liano. Si estos elementos fuesen incorporados en las disposiciones internas de los jueces, fiscales y abogados defensores, se podrían producir cambios en un sistema en donde la estructura de sentido inquisitiva ha sido claramente predominante; a su vez, esto redefiniría la forma en que se distribuye el poder entre los actores legales. La metáfora del trasplante tampoco parece ser lo suficientemente flexible para captar este fenómeno ${ }^{151}$. Incluso cuando un cuerpo humano se tiene que adaptar a un nuevo órgano sigue permaneciendo básicamente inalterado. Pero, a contrario de ello, los cambios producidos en un sistema legal por la transferencia de las reglas, ideas e instituciones legales pueden ser mucho más profundos.

Como consecuencia de las limitaciones que presenta la metáfora del trasplante legal, Günther Teubner ha propuesto la expresión “irritantes legales" para captar este fenómeno ${ }^{152}$. La metáfora del irritante legal claramente sortea los problemas asociados con la del trasplante. En especial tiene la capacidad de transmitir la idea de que la transferencia de una regla o doctrina legal puede provocar una serie de transformaciones en los sistemas legales y sociales receptores. No obstante, la metáfora del irritante legal posee varias deficiencias, siendo una de las más importantes que pierde la dimensión comparativa que ha hecho a la metáfora del trasplante tan poderosa. Un irritante no necesariamente viene de otro sistema (legal) o de afuera del sistema que irrita. Por lo tanto, se pierde la dimensión comparativa de la metáfora tanto entre el sistema original y el receptor, como también entre la idea o práctica original y la que se transfiere.

Frente a estas limitaciones que poseen las metáforas del trasplante y del irritante, aquí propongo la metáfora de la traducción como mecanismo heurístico superior para analizar la circulación de ideas, prácticas e instituciones legales ${ }^{153}$. La metáfora de la traducción retiene la dimensión

${ }^{151}$ En términos botánicos la metáfora del trasplante puede ser más apta para contestar a esta crítica en particular. El trasplante de ciertas especies del ambiente A, al ambiente B, puede producir profundos cambios en el último.

${ }^{152}$ Teubner, "Legal Irritants.." op. cit.

${ }^{153}$ La metáfora de la traducción no se ha utilizado para analizar la circulación de las ideas, reglas, prácticas e instituciones entre sistemas legales, aunque diferentes autores la han usado para analizar otros fenómenos legales. Ver, por ejemplo, White, J.B., Justice as translation: An essay in cultural and legal criticism, University of Chicago Press, 1994; Torres, G., 
De los trasplantes legales a las traducciones legales: la globalización del plea...

comparativa que ha hecho tan poderosa a la del trasplante y que carece la del irritante legal. Con respecto a los sistemas legales, la metáfora de la traducción distingue entre el idioma fuente o sistema legal — de donde proviene la idea o institución legal—, de aquella otra de destino — a la cual la idea o institución legal es traducida ${ }^{154}$ - . La metáfora de la traducción también permite distinguir entre el "texto" original —la idea o institución legal tal como se desarrolla en el sistema legal fuente - y el texto traducido.

$\mathrm{Al}$ convocar nuestra atención sobre las diferencias entre el texto original y el traducido, la metáfora de la traducción también distingue las transformaciones que la idea legal puede sufrir cuando es inicialmente transferida del sistema legal que actúa como fuente, hacia aquél que lo hace como destino $^{155}$. El primer conjunto de transformaciones se deben a las habilidades $y$

“Translation and Stories”, en Harvard Law Review, vol. 115, 2002, p. 1362. Lawrence Lessig ha usado la metáfora para proponer una nueva teoría de interpretación constitucional. Ver Lessig, L., "Fidelity and Constraint", Fordham Law Review, vol. 65, 1997, p. 1365; Lessig, L., "Fidelity in Translation", Texas Law Review, vol. 71, 1993, p. 1165; Lessig, L., "The Puzzling Persistence of Bellbottom Theory: What a Constitutional Theory Should Be", Georgetown Law Journal, vol. 85, 1997, p. 1837; Lessig, L., “Translating Federalism: United States v. Lopez", Supreme Court Review, vol. 1995, p. 125; Lessig, L., "Understanding Changed Readings: Fidelity and Theory", Stanford Law Review, vol. 47, 1995, p. 395. Se pueden ver críticas a la propuesta de Lessig, por ejemplo, en Calabresi, S. G., "The Tradition of the Written Constitution: A Comment on Professor Lessig's Theory of Translation", Fordham Law Review, vol. 65, 1997, p. 1435; Dorf, M. C. "Recipe for Trouble: Some Thoughts on Meaning, Translation and Normative Theory", Fordham Law Review, vol. 65, 1997, p. 1857; Levinson, S., “Translation: Who Needs It?”, Georgetown Law Review, vol. 85, 1997, p. 1457.

${ }^{154}$ Pierre Bourdieu distingue entre el campo de la producción y el de la recepción para captar la circulación de ideas entre países, en áreas como la filosofía, las ciencias sociales y la literatura. Ver Bourdieu, P., "The Social Conditions of the International Circulation of Ideas”, en Shusterman, R. ed. Bourdieu: A critical reader, 1999, p. 221. La distinción entre la producción y la recepción ha sido ampliamente utilizada en los análisis legales. Ver, por ejemplo, Doucet, M. and Jacques V., La réception des systèmes juridiques: implantation et destin, Bruyant, 1994; López-Medina, D., Comparative Jurisprudence: Reception and Misreading of Transnational Legal Theory in Latin America, 2001, pp. 7-12 (tesis doctoral no publicada, Harvard University en el archivo de Harvard Law School Library); Maier, op. cit. $\$ 5(\mathrm{D})(5),(\mathrm{D})(8)$, p. 303,329 y $\$ 8(\mathrm{~A})$, p. 811.

${ }^{155}$ Me refiero aquí a las transformaciones de la idea o institución legal cuando es transferida por primera vez al sistema legal de destino. Como veremos, hay transformaciones que ocurren una vez que la idea o institución legal ha sido incorporada al sistema legal de destino. 
decisiones de los traductores ${ }^{156}$, i.e., los reformadores legales ${ }^{157}$. La historia y teoría de la traducción han planteado tres perspectivas principales sobre la traducción: (1) la literal, que se caracteriza por una "coincidencia palabra por palabra" entre el texto original y el traducido; (2) la "reformulación fiel pero autónoma", en donde el traductor intenta ser fiel al original pero, al mismo tiempo, compone un texto que es igualmente poderoso en el idioma de destino; y (3) la recreación, variación, etc., sustancial, en donde la idea de fidelidad al original se ve debilitada, o directamente desaparece, y el objetivo es crear un texto que sea poderoso o atractivo en el idioma de destino ${ }^{158}$. Si tomamos los ejemplos examinados en esta sección, la traducción de los Estados Unidos a Italia del principio según el cual la prueba debe producirse en el juicio a pedido de las partes, en vez de que sea dispuesta por el juez de oficio, encuadra entre el primer y el segundo criterio ${ }^{159}$. La traducción de la práctica estadounidense del control de constitucionalidad al contexto europeo continental es más cercano al tercero.

El segundo conjunto de transformaciones iniciales del texto pueden originarse en las diferencias entre el idioma fuente y el de destino - las estructuras de interpretación y sentido fuente, y las destinatarias-. Por ejemplo, la palabra "derecho" en español significa en inglés tanto "right" como "law". Por lo tanto, si quisiéramos traducirla del español al inglés

${ }^{156}$ Las capacidades del traductor incluyen no sólo su habilidad para traducir textos (legales), sino también su conocimiento del sistema fuente (legal). Para una referencia clásica sobre esta cuestión, ver Dryden, J., "On Translation”, en Jakobson, R., Schulte, R., \& Biguenet, J., eds., Theories of translation: An anthology of essays from Dryden to Derrida, 1992, pp. 17, 30 .

${ }^{157} \mathrm{El}$ análisis del trabajo de los traductores y sus decisiones y motivaciones es útil para explicar no sólo las transformaciones que el texto original pueda sufrir, sino también por qué la traducción - i.e., la reforma legal - se llevó a cabo en primer lugar. En el campo de los estudios sobre traductorado recientemente ha habido una tendencia a resaltar las motivaciones y poderes de los traductores. Ver, por ejemplo, Bassnett, S., Translation studies, Routledge, 2012, p. 6, 10; Venuti, L., The translator's invisibility: a history of translation, London and New York: Routledge, 1995.

${ }^{158}$ Ver Steiner, G., After Babel: Aspects of Language and Translation, Oxford, Oxford University Press, 1998, p. 266.

${ }^{159}$ Id. p. 266 ("Las líneas divisorias entre los tres tipos necesariamente son borrosas"). Sin embargo, la distinción entre los tres tipos todavía puede ser útil para analizar los procesos de traducción. 
De los trasplantes legales a las traducciones legales: la globalización del plea...

probablemente algo quedaría perdido en el camino al elegir uno de los dos sentidos del término ${ }^{160}$.

Asimismo, la metáfora de la traducción también capta las transformaciones que la idea o práctica legal pueden sufrir en su intercambio con el sistema legal de destino luego de su traducción inicial. Estas transformaciones pueden incluir la neutralización total del "texto" traducido - la regla o práctica legal- sea por medio del ostracismo (desuso o desuetudo) ${ }^{161}$, o de la censura (i.e., declaración de inconstitucionalidad de la práctica) ${ }^{162}$. Además, estas transformaciones pueden incluir una lucha entre los distintos actores y grupos dentro del sistema legal de destino sobre el significado de la institución traducida ${ }^{163}$.

${ }^{160}$ Para un análisis de los obstáculos que presentan las diferencias entre los idiomas a los fines de las traducciones, ver, por ejemplo, Jakobson, R., "On Linguistic Aspects of Translation", en Theories of Translation, op. cit. p. 144, 146-51 (Rainer Schulte \& John Biguenet eds., 1992). La idea de la intraducibilidad de los textos encuentra su origen en estos obstáculos, porque asume que estas diferencias entre los idiomas hace que las traducciones sean imposibles. Sin embargo, muchos estudios actuales sobre traductorado rechazan esta idea de intraducibilidad. Ver, por ejemplo, Friedrich, H., "On the Art of Translation", en Theories of Translation, op. cit., pp. 11, 14-15.

${ }^{161}$ Un ejemplo de este caso de neutralización es la sección 230 del StPO alemán, que dice que los interrogatorios en el juicio deben llevarse a cabo mediante el examen directo y cruzado a solicitud de la fiscalía y la defensa, lo cual es una regla traducida del sistema acusatorio anglosajón. Sin embargo, esta regla se aplica muy pocas veces puesto que, según explica Roxin, no encuadra con la estructura procesal penal de Alemania ya que le quita al presidente del tribunal sus potestades de dirigir el debate. Ver Roxin, C., op. cit., supra nota 66, $\$ 42$, p. 343.

${ }^{162}$ Un ejemplo de esto es la "traducción" de las reglas probatorias estadounidenses en el código procesal penal italiano del año 1989, como la prohibición del testimonio de oídas, que permitió el uso en juicio de las declaraciones tomadas durante la etapa preliminar solamente a los fines de impugnar (impeach) al testigo. La Corte Constitucional de Italia, en su decisión 255/1992, declaró la inconstitucionalidad del art. 500.3 que había introducido esa limitación (Corte cost., 18 mag. 1992, n.255, 104 Racc. uff. corte cost. 1992, 7 [en adelante Decisión 255/1992]). Para un análisis más detallado de esta cuestión, ver infra nota 223.

${ }^{163}$ Por ejemplo, la práctica estadounidense según la cual el equipo de la defensa lleva a cabo su propia investigación preliminar fue traducida a las prácticas italianas en 1989 (D.L.vo 28 lug. 1989, n.271, art. 38, Raccolta Ufficiale degli Atti Normativi della Repubblica Italiana [Racc. Uff.] 1989, vol. 8, 3772, 3780, publicado en Gazzetta Ufficiale della Repubblica Italiana [Gazz. Uff.] 5 ago. 1989, n.182 (en adelante ley 271/1989]). Como estas prácticas iban en contra de la estructura inquisitiva de sentido y las disposiciones internas de un importante número de actores legales, estos actores interpretaron que los elementos de 
Por último, la metáfora de la traducción también es apta para describir la transformación que las prácticas lingüísticas y sociales pueden sufrir bajo la influencia del texto traducido ${ }^{164}$. Considérese la influencia que la traducción al inglés de textos de pensadores como Beccaria, Montesquieu y Voltaire tuvo, no sólo en el vocabulario político, sino también en el pensamiento político de la Revolución de los Estados Unidos ${ }^{165}$. Del mismo modo, la traducción al francés del Commentaries on the Laws of England de Blackstone (1765) tuvo un fuerte impacto en el vocabulario legal francés, y resultó en que un buen número de actores franceses apreciara positivamente al sistema inglés, lo cual culminó con la incorporación del juicio por jurados dos años después de la Revolución Francesa ${ }^{166}$. La traducción de las ideas e instituciones legales puede tener un impacto tanto en el vocabulario como en las prácticas reales del sistema receptor - por ejemplo, modificando antiguas prácticas inquisitivas en la dirección del sistema acusatorio-.

prueba reunidos por la defensa tenían menos valor probatorio que aquellos reunidos por la fiscalía. Por el contrario, quienes apoyaban la reforma acusatoria sostenían que los elementos de prueba reunidos por ambas partes tenían el mismo valor probatorio. Estos últimos, finalmente, impusieron su interpretación con la aprobación de los artículos 391-bis-decies del CPP en D.L.vo 7 dic. 2000, n.397, publicado en Gazz. Uff. 3 gen. 2001, n.2 [en adelante ley $397 / 2000]$.

${ }^{164}$ Varios estudios recientes sobre traductorado se han interesado en este asunto y han mostrado las transformaciones que pueden causar los textos traducidos en las prácticas receptoras lingüísticas y sociales. Ver, por ejemplo, Kenan, L., "Translation as a Catalyst for Social Change in China", en Tymoczko, Maria, y Edwin Gentzler (eds.), Translation and power, Univ of Massachusetts Press, 2002; Lianeri, A., "Translation and the Establishment of Liberal Democracy in Nineteenth-Century England: Constructing the Political as an Interpretive Act", en Translation and Power, op. cit., p. 1.

${ }^{165}$ Sobre la influencia que estos pensadores tuvieron en la Revolución estadounidense, ver Bailyn, B., The ideological origins of the American Revolution, Harvard University Press, 1992, pp. 26-30.

${ }^{166}$ Sobre la traducción de los Comentarios de Blackstone al francés, y su influencia en la percepción positiva del sistema inglés por parte de varios actores franceses, ver Schioppa, A. P., "I Philosophes e la Giuria Penale", I-II Nuova Rivista Storica 107, 1986, p. 107, 123-28. 
De los trasplantes legales a las traducciones legales: la globalización del plea...

\section{El plea bargaining como un Caballo de Troya del sistema acusatorio}

El plea bargaining estadounidense es un mecanismo procesal a través del cual la fiscalía y la defensa pueden alcanzar un acuerdo para la solución de un caso sujeto a la aprobación del tribunal ${ }^{167}$. El acuerdo puede tener diversas formas, pero generalmente consiste en que el acusado se declara culpable (plead guilty) de uno o varios delitos. En contraprestación, la fiscalía desestima otros cargos, acepta que el acusado se declare culpable de un delito menor, o bien solicita - o en todo caso no objeta- que el acusado reciba una condena determinada ${ }^{168}$.

La importación del plea bargaining ejemplifica la traducción de una práctica legal que tiene la potencialidad de "americanizar" las jurisdicciones inquisitivas. Existen muy pocos mecanismos o instituciones que sean más característicos del sistema acusatorio estadounidense y, en especial, del modelo de la disputa ${ }^{169}$. Por definición, el plea bargaining estadounidense

${ }^{167}$ Ver, por ejemplo, Federal Rules of Criminal Procedure p. 11(e)

${ }^{168}$ Ver, por ejemplo, Federal Rules of Criminal Procedure p. 11(e)(1).

${ }^{169}$ Recuérdese que en este artículo utilizo el término "acusatorio" en sentido descriptivo. En ese nivel, y teniendo en cuenta que en el sistema estadounidense se utiliza en forma generalizada a los plea bargains, es razonable considerar a esta práctica como una característica propia de este proceso penal. Además, esta práctica también coincide o es compatible con la concepción del proceso penal como una disputa entre dos partes ante un árbitro pasivo, concepción que se extiende a todo el sistema de justicia estadounidense. Si en lugar de usar esta expresión en sentido descriptivo, se entendiese al sistema acusatorio como un ideal prescriptivo -según el cual, por ejemplo, todos o la mayoría de los casos deben decidirse a través de un juicio por jurados- se podría considerar que los plea bargains no son parte del sistema acusatorio estadounidense, sino que, por el contrario, lo debilitan. Como ya se mencionó anteriormente, las críticas en Estados Unidos contra el plea bargaining han sido muy importantes entre la doctrina y se han basado, al menos en cierta medida, en esta concepción prescriptiva del sistema acusatorio. Ver, por ejemplo, Alschuler, op. cit.; Langbein, J. H., "Torture and Plea Bargaining”, en University of Chicago Law Review, vol. 46, 1978, p. 3; Schulhofer, S. J., "Criminal Justice Discretion as a Regulatory System" Journal of Legal Studies, vol. 17, p. 43; Schulhofer, S. J., "Is Plea Bargaining Inevitable?”, Harvard Law Review, vol. 97, p. 1037; Schulhofer, S. J., "Plea Bargaining as Disaster", en Yale Law Journal, vol. 101, 1991, p. 1979. Se pueden consultar defensas del plea bargaining en Estados Unidos, por ejemplo, en Easterbrook, F. H., "Criminal Procedure as a Market System", Journal of Legal Studies, vol. 12, 1983, p. 289; Easterbrook, F. H., "Plea Bargaining as Compromise", Yale Law Journal, vol. 101, 1991, p. 1969; Scott, R. E. \& Stuntz, W. J., "Plea Bargaining as 
asume la concepción acusatoria del proceso penal como una disputa entre dos partes frente a un órgano decisor pasivo. En el modelo de la disputa tiene sentido que las partes puedan alcanzar un acuerdo a través de una declaración de culpabilidad del acusado. Esto es, las partes pueden negociar a fin de lograr ese acuerdo, y si coinciden en que la controversia está finalizada entonces el órgano decisor no tendría ninguna potestad (o en todo caso tendría una relativamente menor y formal) para rechazar esa decisión ${ }^{170}$.

Pero, además, las características del modelo de la disputa son condiciones que posibilitan el desarrollo del plea bargaining. Por ejemplo, la declaración de culpabilidad (guilty plea), que le permite al acusado poner fin a la etapa de la determinación de culpabilidad o inocencia, le ha brindado a la defensa una herramienta de canje en sus negociaciones con la fiscalía. Al mismo tiempo, el hecho de que el juez, en tanto que órgano decisor pasivo, generalmente acepte el acuerdo alcanzado por las partes (los verdaderos dueños del proceso) también brinda un incentivo para el desarrollo de esas prácticas ${ }^{171}$. Dado que por lo general el juez actúa con deferencia hacia los pedidos de las partes, el acusado puede estar prácticamente seguro de que el acuerdo alcanzado con la fiscalía va a ser homologado; incluso en aquellas situaciones en las que el juez no está limitado por los requerimientos de las partes, tal como ocurre con ciertos acuerdos sobre la pena ${ }^{172}$. Asimismo,

Contract", en Yale Law Journal, vol. 101, 1992, p. 1909. Es importante enfatizar, entonces, que estas críticas del plea bargaining y mi posición de que es un elemento característico del sistema acusatorio estadounidense no son incompatibles, puesto que mientras que en la mayoría de estas críticas se considera el sistema acusatorio como un ideal prescriptivo, en este trabajo lo utilizo como una categoría descriptiva. En otras palabras, se puede decir que el plea bargaining es una característica muy distintiva del sistema acusatorio estadounidense desde una perspectiva descriptiva, y todavía pensar que el plea bargaining es problemático desde una perspectiva normativa o prescriptiva.

${ }^{170}$ En el sistema federal estadounidense el tribunal debe informar al acusado sobre la renuncia de sus derechos, verificar la voluntariedad de la declaración de culpabilidad y establecer si existe base fáctica para ello. Ver generalmente, Federal Rules of Criminal Procedure p. 11. Sin embargo, los tribunales suelen remitirse a los acuerdos alcanzados por las partes.

${ }^{171}$ En sentido inverso, la práctica habitual del plea bargaining entre las partes también refuerza la idea del juez como un árbitro pasivo.

${ }^{172}$ Ver, por ejemplo, Federal Rules of Criminal Procedure. 11(c), que incluye dos tipos de recomendaciones de pena que puede realizar el fiscal: la primera no vincula al tribunal, 
De los trasplantes legales a las traducciones legales: la globalización del plea...

y debido a que el fiscal tiene la potestad para desestimar o disminuir los cargos, las amplias facultades discrecionales que tiene en el modelo de la disputa le otorgan una herramienta poderosa y flexible para negociar con la defensa sobre una declaración de culpabilidad ${ }^{173}$.

Por el contrario, hay pocas prácticas que son más incompatibles con el sistema inquisitivo y el modelo de la investigación oficial que el plea bargaining. Primero, el propio concepto de la declaración de culpabilidad (guilty plea) no existe en el sistema inquisitivo ${ }^{174}$. Segundo, no hay dos partes que negocian y pactan, tal como ocurre en el sistema acusatorio, y que pueden llegar a un acuerdo con respecto a sus respectivas pretensiones, así como también sobre los hechos del caso. En el modelo de la investigación oficial el fiscal no es una parte sino otro funcionario público que, al igual que el juez, tiene que determinar qué ocurrió ${ }^{175}$. En este modelo el fiscal tiene que establecer la verdad "real", la cual no puede ser negociada ni acordada. En todo caso, el juez siempre tendrá la última palabra sobre las conclusiones de la investigación. Igualmente, el mismo acto de negociar con el acusado tradicionalmente ha sido considerado como una conducta inadecuada por parte de estos funcionarios. En las negociaciones y pactos las partes tienen que reconocerse mutuamente como iguales, al menos a cierto nivel. Sin embargo, en el modelo de la investigación oficial, el fiscal, el juez y el acusado no son iguales porque el último tiene un interés en juego en el proceso mientras que los otros dos no.

Además, muchas de las condiciones exigidas para el desarrollo potencial del plea bargaining no existen en el sistema inquisitivo. No sólo que el concepto de la declaración de culpabilidad (guilty plea) no existe en ese sistema, sino que el fiscal también tiene una discrecionalidad mucho más

mientras que la segunda lo vincula sólo luego de que haya aceptado el acuerdo. Para una propuesta de permitir al fiscal establecer el límite máximo de la pena, ver Scott \& Stuntz,op. cit., pp. 1953-57.

${ }^{173}$ La doctrina ha establecido este vínculo entre la discrecionalidad de la fiscalía y los acuerdos. Ver, por ejemplo, Meares, T. L., "Rewards for Good Behavior: Influencing Prosecutorial Discretion and Conduct with Financial Incentives", Fordham Law Review, vol. 64, 1995, pp. 851, 862-73.

${ }^{174}$ Ver Langbien, op. cit., nota 39, pp. 73-74; Moskovitz, op. cit., p. 1153.

${ }^{175}$ Ver Weigend, op. cit., nota 35, pp. 1233-34. 
limitada para decidir qué casos y qué cargos puede presentar, tal como lo simbolizan y regulan el principio de la persecución penal pública obligatoria ${ }^{176}$. Del mismo modo, los jueces suelen no sentirse vinculados por las peticiones que las partes pueden realizar respecto a la pena.

No obstante ello, y a pesar de la aparente incompatibilidad entre el plea bargaining y el modelo de la investigación oficial, hay un gran número de países continental europeos y latinoamericanos que han mostrado recientemente un interés en traducir este mecanismo en sus procedimientos. Las razones varían según la jurisdicción, pero una razón común ha sido el aumento en la tasa de delitos en la mayoría de estos países en los últimos años ${ }^{177}$. Esta situación ha producido un aumento en la carga de sus procedimientos penales, lo cual les ha exigido gestionar más casos en menos tiempo que antes ${ }^{178}$. Por lo tanto, la obtención del consentimiento del imputado mediante negociaciones o la oferta de beneficios, puede derivar en que los procesos penales regulares inquisitivos sean innecesarios, $\mathrm{o}$ al menos puede brindar una justificación para simplificarlos o directamente evitarlos. Si se lo entiende en este contexto, la introducción de mecanismos de negociación consensual ha sido vista como una forma de hacer más flexibles a los rígidos sistemas inquisitivos.

La introducción del plea bargaining en Europa continental y en Latinoamérica es particularmente relevante para el análisis de la tesis de la "americanización". El hecho mismo de que el plea bargaining estadounidense se haya convertido en un punto de referencia en las reformas recientes en el mundo continental europeo y latinoamericano da sustento a la versión débil de esta tesis. Sin embargo, se podría pensar que la propagación del plea bar-

\footnotetext{
${ }^{176}$ Ver supra nota 82.

${ }^{177}$ Para un análisis sobre otros motivos por los cuales las jurisdicciones europeas han traducido a los plea bargains para acomodar sus procesos, ver, por ejemplo, Tulkens, F., "Negotiated justice", European criminal procedures, op. cit., 2002, pp. 645-49.

${ }^{178}$ Con respecto a Argentina, ver infra nota 284. En Francia, el proyecto que introdujo el "plea bargaining" francés tenía como objetivo fortalecer la eficiencia del proceso penal. Ver Cedras, J., "L'hypothèse de l'américanisation du droit pénal français", en Archives de Philosophie du Droit, vol. 45, 2001, p. 149, 156. Con relación a Alemania, ver infra nota 184 y el texto adjunto. Respecto a Italia, ver, por ejemplo, Ferrua, P., "La Giustizia Negoziata nella Crisi della Funzione Cognitiva del Processo Penale", en Studi sul Processo Penal, vol. 3, 1997, pp. 131, 134.
} 
De los trasplantes legales a las traducciones legales: la globalización del plea...

gaining también daría apoyo a la versión fuerte de la tesis. El plea bargaining estadounidense asume una concepción acusatoria del proceso penal. Si los países continental europeos y latinoamericanos tradujeran este mecanismo fielmente, y no lo rechazaran con posterioridad, entonces el efecto de esta importación podría ser que la fiscalía y la defensa empezaran a considerarse a sí mismos como partes en una disputa, y sean percibidos por los otros actores legales de esa manera; algo similar ocurriría con el juez como árbitro pasivo. Si esto ocurriera, entonces se alterarían las disposiciones internas de los actores legales y se produciría un cambio, o, al menos, un cuestionamiento profundo a la estructura de sentido de la investigación oficial por parte de la subestructura de la disputa. Esto podría generar, a su vez, un cambio en las relaciones clásicas de poder de una estructura a la otra, así como cambios en la organización de los recursos humanos y materiales, incluyendo las técnicas de gestión de casos, entre otros elementos.

En otras palabras, se podría pensar al plea bargaining como un Caballo de Troya con el potencial de introducir, escondido en su interior, la lógica del sistema acusatorio en el inquisitivo. Si esto ocurriera, entonces la tesis de la "americanización" sería válida, incluso en su versión fuerte, porque los sistemas inquisitivos que tradujeron el plea bargaining gradualmente comenzarían a "americanizarse" al adoptar la concepción acusatoria del proceso penal.

En las próximas secciones analizo cuatro traducciones específicas del plea bargaining que demuestran los efectos complejos que tiene la circulación de este instituto entre las jurisdicciones continentales europeas y latinoamericanas. Estas secciones dan apoyo a la idea de que la "americanización" no está ocurriendo en todas las jurisdicciones que han adoptado en los últimos años mecanismos inspirados en el plea bargaining, aun cuando en algunas de ellas pueda estar ocurriendo. Los cuatro ejemplos que se analizan son el llamado Absprache en Alemania, el patteggiamento en Italia, el procedimiento abreviado en Argentina y la composition en Francia. Estos cuatro mecanismos han sido explícitamente catalogados como "plea bargaining" o han sido considerados cercanos a aquél en cada uno de estos cuatro países y, en algunos casos, también en Estados Unidos ${ }^{179}$. El análisis

${ }^{179}$ Respecto al Absprachen, ver, por ejemplo, Herrmann, "Bargaining Justice", infra nota 183; Schünemann, "Die Absprachen im Strafverfahren”, infra nota 186, p. 527. Con relación al 
de cada una de estas traducciones se divide en dos partes principales. La primera analiza las similitudes y diferencias entre el plea bargaining estadounidense y el Absprache, el patteggiamento, el procedimiento abreviado y la composition. La segunda analiza los tipos de transformaciones que estas traducciones pueden producir en los procesos penales de Alemania, Italia, Argentina y Francia. La cuestión central en esta sección es determinar si estos procesos inquisitivos siguen manteniendo su modelo tradicional de investigación, si se están moviendo en la dirección del modelo estadounidense de la disputa, o bien si se están moviendo en una dirección distinta a aquellas dos. Este análisis nos va a permitir examinar los cambios que estas reformas pueden producir en los procesos penales de la tradición continental europea y latinoamericana.

\section{El "plea bargaining" alemán}

Al ser una jurisdicción en donde prevalecía el modelo de la investigación oficial, el sistema alemán no se prestaba para la posibilidad de una negociación con el imputado ${ }^{180}$. De hecho, a finales de la década de los setenta, uno de los comparatistas estadounidenses más importantes definía a Alemania como una "tierra sin plea bargaining"181. Sin embargo, durante la década de los setenta los jueces, fiscales y abogados defensores del sistema de justicia penal alemán empezaron a desarrollar acuerdos (Absprachen

pattegiamento, ver, por ejemplo, Ferrajoli, op. cit. Respecto al procedimiento abreviado, ver, por ejemplo, Anitua, G.I., "El juicio abreviado como una de las reformas penales de inspiración estadounidense que posibilitan la expansión punitiva", en El procedimiento abreviado, op. cit., p. 137, 144. Sobre la composition, ver, por ejemplo, Merle y Vitu, op. cit., p. 396.

${ }^{180}$ Ver, por ejemplo, Kühne, H.H., "Germany”,en Van den Wyngaert, C., et al. (eds.), Criminal procedure systems in the European Community, Butterworths, 1999, p. 137, 145 (Christine Van Den Wyngaert et al. eds., 1993. "El principio de 'instrucción" (Instruktionsmaxime), como opuesto al principio de negociación (Verhandlungsmaxime), impone a todas las autoridades involucradas en el proceso penal la obligación de buscar la verdad”. El StPO (Ley procesal alemana) establece el principio de "instrucción" o principio inquisitivo $(\$ \$ 155$ Nr. 2, 244 Nr. 2 STPO). 
De los trasplantes legales a las traducciones legales: la globalización del plea...

o Verständigungen) a escondidas, antes o durante el juicio ${ }^{182}$. Un factor de influencia para este desarrollo fue el aumento en la cantidad de casos penales, y las dificultades y duración de los juicios penales por delitos económicos, ambientales y de tráfico de drogas ${ }^{183}$. En este sentido, la práctica parece haber surgido como una respuesta a necesidades concretas antes que como producto de profundas influencias culturales del sistema estadounidense sobre el alemán. La práctica se mantuvo oculta hasta 1982, cuando se publicó el primer artículo sobre el tema bajo un seudónimo, en donde se indicaba que se trataba de una cuestión delicada para discutir dado que iba contra los principios básicos del proceso penal alemán ${ }^{184}$. A partir de entonces ha tenido lugar un acalorado debate en donde autores muy importantes han criticado y se han opuesto a la práctica, mientras que los tribunales generalmente la han sostenido, aunque imponiéndole determinados límites ${ }^{185}$.

Si bien las formas y el contenido de las negociaciones y acuerdos alemanes son diversas, la idea básica es la siguiente: durante la preparación del juicio, o bien durante el mismo juicio, el acusado puede ofrecer confesar en el debate a cambio de que el juez le garantice que la pena no será superior a cierto límite, o que un determinado número de cargos va a ser desestimado por la fiscalía ${ }^{186}$. Estas negociaciones pueden ser iniciadas

${ }^{182}$ Ver Herrmann, J., “Bargaining Justice--A Bargain for German Criminal Justice?”, University of Pittsburgh Law Review, vol. 53, 1992, p. 755, 755-57.

${ }^{183}$ Ver Roxin, op. cit., $\$ 15$, p. 95; Frase \& Weigend, op. cit., p. 345

${ }^{184}$ Deal, D., "Der strafprozessuale Vergleich", en Strafverteidiger, vol.2, 1982, p. 545

${ }^{185}$ Para un análisis de este debate en inglés, ver Swenson, T., “The German 'Plea Bargaining' Debate", Pace International Law Review, 1995, vol. 7, p. 373. Uno de los críticos más importantes de estas prácticas ha sido el profesor Bernd Schünemann. Ver, por ejemplo, Schünemann, B. and Deutscher J., Absprachen im Strafverfahren?: Grundlagen, Gegenstände und Grenzen: Gutachten B für den 58. Deutschen Juristentag, CH Beck, 1990. Los acuerdos no han sido formalmente introducidos en el Código Procesal Penal de Alemania. Ver, por ejemplo, Weigend, T., "Abgesprochene Gerechtigkeit-Effizienz durch Kooperation im Strafverfarhern?”, Juristenzeitung, vol. 45, 1990, p. 774, 775 (en donde sostiene que el Código Procesal Penal alemán no menciona a los acuerdos). Nota de actualización de la versión original: años después de la publicación de la versión original en inglés de este artículo, los acuerdos o entendimientos fueron formalmente introducidos en el Código Procesal Penal Alemán $(\$ 257 \mathrm{c}$ ) y regulados también en otras secciones de este código.

${ }^{186}$ En este artículo sólo analizaré aquellos acuerdos que han generado mayor controversia en el sistema de justicia penal alemán. Existen otros dos mecanismos que también han 
por la defensa, el juez o la fiscalía. No es necesario que todos los actores legales participen, con lo cual las negociaciones se pueden llevar a cabo solamente entre el juez del debate y la defensa ${ }^{187}$. Sin embargo, todos los actores del caso deben ser informados del acuerdo en el juicio ${ }^{188}$. Además, los acuerdos requieren de la cooperación y la confianza mutua entre el juez, la fiscalía y la defensa ${ }^{189}$.

Como queda claro de esta descripción, las transformaciones que sufrió el plea bargaining estadounidense al ser traducido al sistema procesal penal alemán son sustanciales ${ }^{190}$. Primero, las negociaciones y acuerdos alemanes (Absprachen o Verständigungen) no se refieren a declaraciones de culpabilidad (guitly pleas), sino a meras confesiones. Por ende, si bien el acuerdo generalmente acorta el juicio, ya que con la confesión se facilita la prueba de los hechos que son materia de acusación, de todos modos no lo reem-

sido comparados con el plea bargaining estadounidense. El primero es el procedimiento de la orden penal - Strafbefehlsverfahren - regulado en las secciones 407-12 de la StPO. En este procedimiento el fiscal en vez de remitir el caso a juicio, solicita al juez una orden penal. El fiscal prepara un borrador de la orden penal en donde describe los detalles del caso y solicita una consecuencia legal específica que puede incluir una multa, el retiro del permiso de conducir, o incluso el encarcelamiento hasta un año a cumplirse en probation. Si el juez convalida el borrador, entonces se notifica al acusado quien debe oponerse si pretende evitar su ejecución. Este procedimiento se utiliza para manejar el núcleo de las infracciones penales menores. Para una descripción en inglés, ver Herrmann, op. cit., pp. 760-63. Este procedimiento ha sido comparado con el plea bargaining porque el fiscal y la defensa pueden negociar con respecto a la consecuencia de la orden penal. Ver, por ejemplo, Frase \& Weigend, op. cit. en nota 111, p. 345. El segundo procedimiento que ha sido comparado con el plea bargaining es el establecido en \$153(a) del StPO. En casos sobre delitos menores este procedimiento autoriza a la fiscalía, con el consentimiento del tribunal y del imputado, a desestimar el caso condicionado al cumplimiento de una condición por parte del imputado. Esta condición puede incluir la reparación del daño causado por el delito, la realización de tareas comunitarias, etc. En este sentido, es similar a la práctica estadounidense de la diversion. Este procedimiento se incorporó al Código Procesal Penal de Alemania en 1975, ver Herrmann, op. cit., p. 757. Para un análisis de este mecanismo en inglés, ver id.

${ }^{187}$ Ver, por ejemplo, Swenson, op. cit., pp. 378-79.

188 "Entscheidungen des Bundesgerichtshofes in Strafsachen" [BGHSt] [Corte Suprema Penal] 43, 195 (195, 205-06) (F.R.G.).

${ }^{189}$ Ver, por ejemplo, Swenson, op. cit., p. 378.

${ }^{190} \mathrm{El}$ plea bargaining estadounidense ha sido el modelo de referencia y un factor que fomentó el desarrollo de estas prácticas de negociación. Ver Weigend, op. cit., p. 186. 
De los trasplantes legales a las traducciones legales: la globalización del plea...

plaza en su totalidad ${ }^{191}$. Segundo, como la defensa tiene acceso completo al expediente escrito que contiene la investigación preliminar -la fiscalía tiene un deber de divulgación completo hacia la defensa en el sistema alemán-, la defensa posee un mejor conocimiento del caso que el que tiene su similar estadounidense durante las negociaciones ${ }^{192}$. Tercero, el juez que preside el juicio generalmente es un participante activo en estas negociaciones y acuerdos. Habitualmente los dos principales actores de la negociación en el sistema alemán no son la fiscalía y la defensa, como ocurre en el sistema estadounidense, sino el juez que preside el caso y la defensa ${ }^{193}$.

Estas diferencias sustanciales entre el plea bargaining estadounidense y los Absprachen alemanes revelan lo insuficiente que es la "metáfora del trasplante legal" para captar el fenómeno de las influencias legales. Es erróneo sostener que el plea bargaining estadounidense ha sido trasplantado a Alemania porque esta afirmación conlleva la falsa idea de que el mismo mecanismo legal existe en ambos países. Por el contrario, la metáfora de la traducción explica la posibilidad de que puedan desarrollarse diferencias sustanciales entre la práctica legal originaria y la traducida. A través de la metáfora de la traducción se pueden explicar las diferencias que sufrieron los "plea bargains" estadounidense y alemán con su traducción desde un sistema con una estructura de interpretación y sentido prevalecientemente acusatoria, hacia otro sistema dominado por una estructura de sentido inquisitiva. Los traductores del "plea bargaining" alemán silenciosamente introdujeron la práctica conscientes de que su legitimación y significado era cuestionable en la estructura de sentido alemana. Así, por ejemplo, no tenían la autoridad para modificar formalmente otros aspectos del procedimiento penal mediante una reforma del Código Procesal Penal. Estas

\footnotetext{
${ }^{191}$ Ver Herrmann, supra nota 183, p. 764.

${ }^{192}$ Id. La Corte Suprema de Estados Unidos ha declarado que el fiscal no tiene una obligación constitucional de revelar pruebas que podrían servir para cuestionar a los testigos (impeachment) o sobre defensas afirmativas (affirmative-defenses) antes de la declaración de culpabilidad del acusado. Ver United States v. Ruiz, 536 U.S. 622 (2002). Para un análisis de los problemas que presentan para los plea bargains los deberes limitados de los fiscales de revelar las pruebas a la contraparte (discovery) en los Estados Unidos, ver, por ejemplo, Ostrow, E. J., "The Case for Preplea Disclosure", Yale Law Journal, vol. 90, 1981, p. 1581.

${ }^{193}$ Ver Herrmann, op. cit., p. 764.
} 
restricciones limitaron el rango de sus poderes de decisión y descartaron toda posibilidad de fidelidad al modelo del plea bargaining estadounidense con la traducción de la nueva práctica.

Estas limitaciones de su poder de los traductores significaron que los traductores tuvieron que negociar sustancialmente con la estructura de interpretación y sentido inquisitiva preexistente, con las disposiciones internas predominantes entre los actores legales alemanes y con la estructura de poder procesal. Por ejemplo, el procedimiento penal alemán no incluía el concepto de la declaración de culpabilidad (guilty plea), y no había ninguna reforma legal que pudiera introducirlo. Entonces, los traductores tuvieron que tratar a la admisión negociada no como una declaración de culpabilidad (guilty plea), sino como una confesión. Esto significó que los juicios de todos modos deben realizarse, incluso cuando pueden ser acortados mediante los Absprachen. Además, en la estructura de interpretación y sentido inquisitiva el juez es un participante activo en el juicio, de hecho es el más poderoso ${ }^{194}$. Consecuentemente, cualquier acuerdo para resolver los casos en forma rápida que pretenda ser viable debe incluirlo, y en la práctica el juez juega un papel central en las negociaciones; sólo él puede asegurarle al acusado que la pena no será superior a determinado límite, y sólo él tiene control sobre la potestad de la fiscalía de desestimar los cargos en la etapa del debate. Por ende, la traducción del plea bargaining a las prácticas alemanas tuvo que ser adaptada a los poderes procesales preexistentes en donde el juez sobresalía como la figura más importante en el juicio.

La siguiente cuestión a explorar es qué tipos de transformaciones estas prácticas pueden producir en el proceso penal alemán en el futuro. El plea bargaining estadounidense tiene la potencialidad de transformar la estructura de interpretación y sentido alemana, las disposiciones internas de sus actores legales y la distribución de los poderes procesales entre ellos. Sin embargo, en este caso, los Absprachen alemanes no parecen ser un Caballo de Troya que contenga al modelo de la disputa estadounidense. El juez alemán sigue siendo el actor más activo en el juicio y no se ha transformado en un árbitro pasivo. Por lo tanto, aun cuando una amplia adopción de esta 
De los trasplantes legales a las traducciones legales: la globalización del plea...

práctica afecte la forma en que los jueces alemanes perciben sus roles y son percibidos por otros actores legales, lo cierto es que el resultado final no será su transformación en un órgano decisor pasivo ${ }^{195}$.

Sin embargo, ¿seguiría siendo el juez un investigador oficial de la verdad si esta práctica impusiera su lógica sobre el resto del sistema de justicia penal alemán? En otras palabras, ¿podría el modelo de la investigación oficial absorber y sobrevivir a esta traducción, o se vería radicalmente transformado por ella? Cualquiera de estos escenarios es posible.

El modelo de la investigación oficial puede absorber los acuerdos de confesión en la medida en que la mayoría de los actores legales entiendan y utilicen a estos acuerdos como herramientas para descubrir la verdad, en lugar de como mecanismos para resolver los casos penales en forma rápida ${ }^{196}$. De hecho, el ofrecimiento de beneficios al acusado a cambio de una confesión detallada, lo cual serviría como una circunstancia atenuante a los fines de la determinación de la pena, no es para nada novedosa en el modelo de la investigación oficial. Así, los acuerdos de confesión pueden ser interpretados como una extensión de esta práctica.

Hay dos decisiones importantes que indican que un gran número de

${ }^{195} \mathrm{Si}$ bien no hay datos oficiales con respecto al alcance con el cual esta práctica es empleada, según Weigend, diversas estimaciones y encuestas indican que aproximadamente uno de cada cuatro juicios es resuelto mediante un acuerdo. Weigend, supra nota 191, p. 774. Esto indica que los jueces, fiscales y abogados defensores han aceptado ampliamente la nueva práctica. Los incentivos que la nueva práctica genera para los jueces, fiscales y abogados defensores -i.e., la reducción en la cantidad de causas y su resolución más rápida- parece ser la principal razón de esta aceptación generalizada. Para un análisis de estos incentivos, ver Schünemann, B., "Die Absprachen im Strafverfahren", en Hanack, Ernst-Walter, et al., eds. Festschrift für Peter Riess zum 70. Geburtstag am 4. Juni 2002, Walter de Gruyter, 2011.

${ }^{196} \mathrm{El}$ sistema de la investigación oficial también podría sobrevivir si las prácticas de negociación fuesen censuradas - i.e., a través de su prohibición legal -. Aún cuando algún sector de la doctrina ha sugerido esta posibilidad, la discusión entre jueces, fiscales y abogados defensores no se ha focalizado en la eliminación de estas prácticas de negociación, sino en cómo deben interpretarse. Al parecer esta limitación en la discusión se debe a los incentivos que los jueces, fiscales y abogados defensores han tenido para apoyar estas prácticas de negociación. El hecho de que los doctrinarios no estén bajo el mismo sistema de incentivos, quizá explique por qué han sido más fieles a sus disposiciones inquisitivas internas pre-existentes que aquellos que practican el derecho. Sobre las profundas divisiones entre la mayoría de la doctrina y los practicantes con respecto a los acuerdos, ver, por ejemplo, Weigend, T., "Eine Prozessordnung für abgesprochene Urteile?”, Neue Zeitschrift für Strafrecht [NSTZ] 57, 1999. 
actores legales en el sistema de justicia penal alemán están tratando de interpretar y conducir a los acuerdos de confesión en esta dirección. Primero, en su único pronunciamiento sobre el tema ${ }^{197}$, el Tribunal Constitucional Federal (BVerfG) sostuvo que estos acuerdos son admisibles siempre que no violen el concepto constitucional de Rechtsstaat - Estado de derecho - y un conjunto de principios sustantivos y procesales ${ }^{198}$. Entre estos principios, el BVerfG mencionó aquel que obliga a los jueces y fiscales a investigar la verdad material ${ }^{199}$. En consecuencia, el juez no puede condenar a un acusado con base en un acuerdo de confesión si debería haber considerado que tenía el deber de considerar más pruebas ${ }^{200}$.

Además, en su decisión del 28 de agosto de 1997, la Corte Suprema Federal de Alemania analizó en detalle, y por primera vez, los requisitos que debían cumplir estos acuerdos para que sean considerados admisibles $^{201}$. Al respecto, dijo que no debía haber una violación del deber judicial de establecer la verdad ${ }^{202}$. Esto significa, por ejemplo, que el tribunal no puede basar su sentencia sólo en una confesión obtenida a través de un acuerdo, sino que debía examinar la credibilidad de esa confesión y, eventualmente, ordenar la producción de prueba adicional en el juicio ${ }^{203}$.

Se puede concluir, entonces, que estas dos decisiones consideran que la confesión obtenida es algo distinto a un guilty plea. El acuerdo de confesión no puede ser un justificativo procesal para resolver un caso penal. Por el

${ }^{197}$ Bundesverfassungsgericht [BverfGE] [Tribunal Constitucional Federal] (Sentencia del 27 de enero de 1987), citada en Volker Gallandi "Absprachen im Strafprozess", NSTZ, 1987 419. [Nota de actualización de la versión original en inglés: el Tribunal Constitucional alemán emitió el 19 de marzo de 2013 una nueva decisión sobre los acuerdos].

${ }^{198}$ Ver id. p. 419 (en donde se discuten los principios de culpabilidad o mens rea - das Schuldprinzip - e igualdad o igual protección - der Gleichheitssatz - como también limitaciones a los Absprachen).

${ }^{199} \mathrm{Id}$. El principio de la investigación (der Ermittlungsgrundsatz), también llamado principio de la verdad material o principio inquisitivo, significa que el juez realiza su propia investigación del caso. Este principio está establecido en el Código Procesal Penal alemán (StPO) en las secciones 155 Nr. 2 y 244 Nr. 2. Ver Roxin, op. cit. en nota 66, \$15 p. 95.

${ }^{200}$ BverfGE (Sentencia del 27 de enero de 1987), citada en Volker Gallandi, op. cit., p. 419, 419.

${ }^{201}$ BGHSt 43, 195 (F.R.G.).

${ }^{202}$ Id. p. 204.

${ }^{203}$ Id. Para un análisis de esta decisión y otros requisitos impuestos sobre los acuerdos, ver Roxin, op. cit., $\$ 15$ p. 96-97. 
De los trasplantes legales a las traducciones legales: la globalización del plea...

contrario, tiene que brindar elementos de prueba y ser lo suficientemente creíble para dar apoyo a una condena penal. De lo contrario, el tribunal tiene que producir elementos de prueba adicionales en el juicio.

Pese a ello, ha existido una segunda tendencia dentro del proceso penal alemán a interpretar a estas confesiones acordadas como el equivalente al guilty plea ${ }^{204}$. Un ejemplo de esta tendencia lo constituye la decisión del 10 de junio de 1998 dictada por un senado distinto de la Corte Suprema Federal $^{205}$. En este caso, luego de que se leyera la acusación al comienzo del juicio, el tribunal le preguntó al acusado si el contenido de la acusación era correcto, a lo cual aquél contestó afirmativamente. Con base en esta simple aceptación el tribunal condenó al acusado y le impuso una pena de ocho años de prisión. El BGHSt, a través de su Sala Segunda, confirmó la decisión ${ }^{206}$.

La interpretación sobre cuáles son los efectos de esta confesión acordada es central en la discusión entre dos concepciones diferentes del proceso penal. Según la primera de ellas, que ha sido dominante en Alemania por mucho tiempo, el proceso penal es una investigación llevada a cabo por el juez y el fiscal a fin de establecer la verdad. En este contexto, el acuerdo de confesión se puede adaptar a esta estructura procesal de interpretación y sentido, si es interpretado y utilizado como una herramienta para descubrir la verdad.

De acuerdo con la segunda concepción, el procedimiento penal es sólo una "línea de montaje" que procesa los casos penales lo más rápido posi$b^{207}$. Es importante recordar, sin embargo, que el principal director de esta "línea de montaje" en el plea bargaining alemán no es el fiscal, tal como

${ }^{204}$ Esto muestra cómo la traducción de los acuerdos al proceso penal alemán puede, eventualmente, transformar el significado de conceptos legales particulares, como el concepto de la confesión, e incluso el modelo de la investigación oficial en su conjunto.

${ }^{205}$ Bundesgerichtshof [BGH] [Tribunal Federal de Justicia] (Sentencia del 10 de junio de 1998), citada en "Angabe des Grundes für den Ausschluss der Öffentlichkeit”, 1999 NSTZ, p. 92.

${ }^{206}$ Id. p. 93.

${ }^{207}$ Por supuesto que la referencia es al famoso modelo de control del delito de Herbert Packer que concibe al proceso penal como una "línea de montaje", y se opone al modelo del debido proceso que concibe al proceso penal como una "carrera de obstáculos". Ver Packer, op. cit. Sin embargo, y como explicaré, este modelo alemán difiere del modelo de control del delito de Packer, aun cuando comparten el objetivo de resolver los casos penales rápidamente. 
ocurre con el modelo estadounidense de la disputa, sino que es el juez de juicio $^{208}$. Pero aun cuando el juez sea el principal director del caso, todavía necesita de la cooperación de la defensa y la fiscalía, puesto que la resolución del caso sólo es posible mediante su participación. Esto significa que si esta tendencia prevaleciera en Alemania, entonces su estructura de interpretación y sentido predominante no sería ni el modelo de la investigación oficial ni el modelo de la disputa. Sería algo distinto que provisoriamente llamaré el "modelo del juez-gerente basado en la cooperación"209.

En este sistema del juez-gerente su rol no es ni el de un árbitro pasivo, ni el de un investigador activo. Por el contrario, tiene que asegurar que los casos penales sean procesados lo más rápido posible. Para ello, y haciendo uso de su mayor poder, presiona sutilmente (o no tan sutilmente) a la fiscalía y la defensa para que colaboren con la pronta resolución del caso ${ }^{210}$. El

${ }^{208}$ Este rol activo del juez distingue esta tendencia en el proceso penal alemán del modelo de control del delito de Packer. Este modelo presupone la existencia del sistema acusatorio (ver op. cit. p. 157), y por lo tanto de un juez relativamente pasivo. Pero como en Alemania este juez es activo, el modelo alemán difiere del de Packer.

${ }^{209}$ El modelo del juez-gerente basado en la cooperación tiene semejanzas con tendencias en el proceso civil estadounidense según las cuales el juez es un gerente activo de la controversia, mas que un árbitro pasivo como en el sistema acusatorio. Entre los principales artículos que describen algunos de estos cambios en el proceso civil estadounidense, se pueden consultar, por ejemplo, Chayes, A., "The Role of the Judge in Public Law Litigation”, Harvard Law Review, vol. 89, 1976, p. 1281; Fiss, O. M., "Foreword: The Forms of Justice", Harvard Law Review., vol. 93, 1979, p. 1; y Resnik, J., Managerial Judges, Harvard Law Review., vol. 96, p. 374 (1982). Para un análisis que cuestiona que estos desarrollos sean enteramente novedosos en el proceso civil estadounidense, ver Eisenberg, T. \& Yeazell, S. C., "The Ordinary and the Extraordinary in Institutional Litigation", en Harvard Law Review., vol. 93, 1980, p. 465. Para un análisis que cuestiona que estos desarrollos describan adecuadamente el litigio civil de casos complejos estadounidense actual, ver Rubenstein, W. B., "A Transactional Model of Adjudication", Georgetown Law Review, vol. 89, 2001, p. 371.

${ }^{210}$ Aunque la mayoría de los plea bargains estadounidenses se realizan como consecuencia de las negociaciones llevadas a cabo exclusivamente entre la fiscalía y la defensa, hay algunos jueces que, en ciertas ocasiones, estimulan a las partes a que alcancen un acuerdo a fin de evitar el juicio. En este sentido, el modelo de la gestión del juez-gerente basado en la cooperación también tendría cierta presencia en Estados Unidos. No obstante, esta práctica es relativamente menor entre los plea bargains estadounidenses, al menos en el sistema regular de justicia penal federal, y el sistema de la disputa sigue siendo predominante en este país. Este tipo de prácticas son más habituales en los casos civiles estadounidenses. Ver, por ejemplo, Resnik, op. cit. 
De los trasplantes legales a las traducciones legales: la globalización del plea...

fiscal es considerado un colaborador del juez quien también contribuye al procesamiento expedito de los casos penales. El abogado defensor es tanto un representante del acusado, que tiene que obtener el mejor resultado posible para su mandante, así como también un actor legal profesional, que tiene el deber de colaborar con los otros actores legales profesionales en la pronta resolución de los $\operatorname{casos}^{211}$.

Pero esto no significa que la verdad no cumpla ningún papel en este modelo. Al igual que en el modelo de la disputa y en el de la investigación oficial, nadie quiere condenar a un inocente o absolver a un culpable. Sin embargo, el descubrimiento de la verdad es un objetivo tan importante como la resolución expedita del caso, y en consecuencia el proceso no está estructurado como una investigación ${ }^{212}$.

Establecer cuál es la verdadera importancia del sistema del juez-gerente basado en la cooperación en el proceso penal alemán actual es una cuestión empírica que excede el alcance de este artículo ${ }^{213}$. Lo que quiero enfatizar aquí es que ya existen indicaciones de que este sistema tiene cierta presencia, al menos en forma incipiente, en el proceso penal alemán

${ }^{211}$ Con respecto a la redefinición del rol del abogado defensor en los acuerdos alemanes, ver Weigend, op. cit. nota 191, p. 779.

${ }^{212}$ La concepción de la verdad en el modelo del juez-gerente basado en la cooperación es más relativa y consensual que en el sistema inquisitivo. Si la fiscalía, la defensa y el tribunal acuerdan que los eventos se produjeron de determinada manera - i.e., mediante confesiones acordadas - el modo en que los hechos ocurrieron realmente se vuelve menos importante. En este sentido, la concepción de la verdad en este modelo presenta semejanzas con la concepción de la verdad en el sistema acusatorio. Por lo tanto, aun cuando la traducción de los acuerdos de confesión no están llevando a las prácticas alemanas en la dirección del modelo de la disputa, los Absprachen tienen el potencial de introducir una concepción de la verdad más cercana a aquella del sistema acusatorio. Si este potencial se cumpliese, el resultado sería una "americanización" del sistema alemán con respecto a la concepción de la verdad aun cuando no haya una "americanización" con respecto al modelo de la disputa. Esto muestra que la "americanización" no es un juego a todo o nada. La introducción de los Absprachen alemanes eventualmente podría crear nuevas divergencias con el modelo estadounidense de la disputa, debido al avance del modelo del juez-gerente basado en la cooperación y, al mismo tiempo, una convergencia con el sistema acusatorio estadounidense en una concepción de la verdad más relativa y consensual.

${ }^{213}$ Dejo para un trabajo futuro el análisis más detallado del modelo del juez-gerente basado en la cooperación, así como la cuestión de si se podría estar desarrollando en otras jurisdicciones además de Alemania. 
contemporáneo, y que este sistema difiere tanto del modelo de la disputa como del de la investigación oficial. También, en cierta medida, el modelo parece haber sido desarrollado como consecuencia de la traducción de los acuerdos negociados en ese país durante la década del setenta, y como consecuencia de las negociaciones que tuvieron que hacer los traductores legales con la estructura de interpretación y sentido, con las disposiciones internas predominantes entre los actores legales y con la distribución de las potestades procesales preexistentes.

Resumiendo, la estructura procesal de interpretación y sentido que prevalecía en Alemania en la década del setenta era el sistema inquisitivo con su modelo de investigación oficial, y la mayoría de los actores habían incorporado esa estructura a sus disposiciones internas. Debido a cambios sociales externos que aumentaron la cantidad y complejidad de los casos penales, los actores legales de Alemania recibieron fuertes incentivos para modificar sus actitudes hacia los acuerdos y negociaciones con el acusado. Sin embargo, el plea bargaining sufrió una profunda transformación cuando fue traducido de una estructura de sentido acusatoria a una configuración inquisitiva debido a la estructura procesal de interpretación y sentido, las disposiciones individuales predominantes y la estructura de poderes procesales preexistentes, todo lo cual neutralizó, en cierta medida, su potencial efecto acusatorio o de "americanización" sobre el proceso penal alemán. Sin embargo, este nuevo mecanismo significó un cuestionamiento a la estructura de sentido inquisitiva basada en el modelo de la investigación oficial prevaleciente. Todavía queda por verse la seriedad de este cuestionamiento, lo cual debe establecerse a través de estudios empíricos. Pero desde la introducción de los Absprachen o Verständigungen ha habido una lucha entre el modelo de la investigación oficial por adaptar este nuevo mecanismo a su propia lógica, y el modelo del juez-gerente con base en la cooperación para interpretarlo en sentido distinto. Esta lucha debería ser entendida no sólo en términos abstractos, como una colisión entre dos estructuras de interpretación de sentido, sino también como una lucha entre actores legales con disposiciones internas que se corresponden con esas estructuras de sentido ${ }^{214}$. Las interaccio- 
De los trasplantes legales a las traducciones legales: la globalización del plea...

nes entre estas dos estructuras de sentido $-\mathrm{y}$ otros estructuras que están presentes en la sociedad y en el proceso penal alemán - también pueden impactar sobre otros aspectos de las prácticas de la justicia penal de Alemania, tales como la organización de los recursos humanos y materiales, la ética legal, etc. El análisis de estos cambios debería incluirse en un estudio más amplio sobre las transformaciones producidas por la traducción del plea bargaining en Alemania.

Desde la perspectiva del debate sobre la tesis de la "americanización" el ejemplo alemán muestra que, debido a la transformación que sufrió en su traducción y las interacciones subsiguientes, los Absprachen no han "americanizado" el proceso penal alemán en el sentido de que no han introducido la concepción cultural del proceso penal como una disputa entre la fiscalía y la defensa ante un órgano decisor pasivo. Por el contrario, debido a su traducción legal este proceso puede encontrarse en una encrucijada entre su modelo tradicional inquisitivo del proceso penal y un modelo que no es inquisitivo ni acusatorio.

\section{E1 "plea bargaining" italiano}

Comparado con los Absprachen alemanes, el plea bargaining italiano, o patteggiamento, ha sido mucho más fidedigno al modelo estadounidense, aun cuando presente diferencias sustanciales con la práctica estadounidense. Los traductores legales italianos tuvieron mucho más poder que los alemanes para llevar a cabo su reforma, y pudieron introducir el plea bargaining italiano como parte de una serie de reformas más amplias y profundas inspiradas en el sistema acusatorio estadounidense. Así, los reformistas italianos tuvieron que realizar muchos menos compromisos que los traductores alemanes, y tuvieron mucho más poder para modificar la estructura de sentido inquisitiva preexistente, la distribución de poderes procesales, etc. Como estas reformas acusatorias han contado con un apoyo político sustancial, han logrado mover al sistema italiano en la dirección del sistema

de los propios actores legales individuales que poseen una ambivalencia interna sobre ambos sistemas. 
acusatorio estadounidense mucho más que cualquier otra jurisdicción continental europea y latinoamericana ${ }^{215}$. Sin embargo, incluso en el sistema italiano actual muchos actores legales siguen actuando de acuerdo con un conjunto de disposiciones internas predominantemente inquisitivas. Además, las estructuras de interpretación y sentido y los poderes procesales inquisitivos siguen estando presentes.

En 1989 Italia adoptó un nuevo código procesal penal que reemplazó al Código Procesal Penal de Rocco promulgado durante el régimen de Mussolini ${ }^{216}$. Este nuevo código representó el intento más serio de transferir un procedimiento penal acusatorio a una jurisdicción inquisitiva desde 1791, cuando Francia quiso importar el sistema inglés durante el calor de la Revolución ${ }^{217}$. La reforma italiana fue justificada como una mejora en términos de debido proceso y de eficiencia, aunque predominantemente se inspiró en el debido proceso ${ }^{218}$. El proceso penal estadounidense fue el principal modelo para estas reformas acusatorias debido al prestigio que su sistema legal en general, y su proceso penal en particular tuvo entre un número sustancial de actores legales desde el final de la Segunda Guerra Mundial ${ }^{219}$.

Las reformas acusatorias pueden ser descriptas y analizadas utilizando los dos pares de modelos desarrollados en la sección III: el modelo de la coordinación vs. el de la jerarquía, y el modelo de la disputa vs. el de la investigación oficial ${ }^{220}$.

Con respecto al primer par, los encargados de la reforma intentaron importar la oralidad como técnica de gestión de casos propia del modelo de la coordinación, mediante la reducción de la importancia de la prueba recolectada durante la etapa preliminar en el expediente escrito carac-

\footnotetext{
${ }^{215}$ Nota de actualización: la referencia es a la fecha de escritura de este artículo en 2002-3.

${ }^{216}$ En este sentido, la introducción del código podría ser analizada como parte de la transición hacia la democracia que comenzó Italia después de la Segunda Guerra Mundial.

${ }^{217}$ La clásica descripción sobre esta importación es Esmein, op. cit. nota 63, pp. 399-480.

${ }^{218}$ Ver Vassalli, op. cit.

${ }^{219}$ Ver Grande, op. cit., nota 32, pp. 230-32.

${ }^{220}$ Se pueden consultar diversos análisis en inglés sobre estas reformas, en Amodio \& Selvaggi, op. cit., nota 115; Freccero, S. P., "An Introduction to the New Italian Criminal Procedure", en American Journal of Criminal Law, vol. 21, 1994, p. 345; Pizzi, W. T. \& Marafioti, L., "The New Italian Code of Criminal Procedure: The Difficulties of Building an Adversarial Trial System on a Civil Law Foundation", Yale Journal of International Law, vol. 17, 1992, p. 1.
} 
De los trasplantes legales a las traducciones legales: la globalización del plea...

terístico del sistema inquisitivo ${ }^{221}$. Para ello ordenaron la preparación de un legajo especial para el juicio de modo que el tribunal no tuviese conocimiento de los testimonios tomados durante las etapas anteriores al debate $222, y$ también se incorporaron reglas probatorias, como la que prohíbe el testimonio de oídas (hearsay), que determinó que el testimonio tomado en las etapas anteriores al juicio no pudiera ser admitido en el juicio, excepto para impugnar (impeach) al testigo ${ }^{223}$.

Con respecto al segundo sub-sistema, los reformistas italianos introdujeron numerosos cambios para promover el modelo de la disputa dentro del sistema italiano. Primero, ahora se supone que las partes tienen que llevar a cabo el proceso de determinación de los hechos, tanto en la etapa preliminar como en el juicio. Esto significó eliminar a la figura del juez de instrucción (giudice istruttore) como el órgano que colecta la prueba en la etapa preparatoria ${ }^{224}$, y reemplazarlo por el fiscal y el abogado defensor, quienes ahora pueden realizar sus propias investigaciones ${ }^{225}$. Ello también supuso que el juicio se organizara de acuerdo con el caso de la fiscalía y el de la defensa ${ }^{226}$, y se introdujo el examen directo y cruzado como la forma de interrogar a los testigos en el juicio ${ }^{227}$. Además de estas y otras reformas, el código de Italia incluye una regla que establece que el juez sólo puede

${ }^{221}$ Ver, por ejemplo, Amodio \& Selvaggi, op. cit., p. 1217.

${ }^{222}$ CPP art. 431 (1989) (Italia).

${ }^{223}$ CPP arts. 500, 503 (1989) (Italia). La reacción inquisitiva contra estas ideas -combinadas con una delicada situación política, en la cual dos de los principales jueces anti-mafia habían sido asesinados- vino un par de años luego de la reforma, cuando el Tribunal Constitucional de Italia, en sus decisiones 254/1992 y 255/1992, declaró la inconstitucionalidad del art. 513.2, y arts. 500.3 y 500.4. Decisión 255/1992, supra nota 163; Corte cost., 18 mag. 1992, n.254, 103 Racc. uff. corte cost. 1992, 809. Sin embargo, en 1999, el Parlamento italiano aprobó un nuevo artículo 111 de la Constitución italiana, apoyando la dirección original de las reformas de 1989 hacia un mayor rol de las técnicas de gestión oral de casos del modelo de la coordinación.

${ }^{224}$ Ver Vassalli, op. cit., nota 115, p. 6.

${ }^{225}$ Con respecto a las potestades de la fiscalía de realizar la investigación preliminar, ver CPP art. 358 (Italia). Las potestades investigativas de la defensa fueron incluidas en la Ley 271/1989, supra nota 164, y luego incorporadas en el Código Procesal Penal, artículos 391-bis-decies por Ley 397/2000, supra nota 164.

${ }^{226} \mathrm{CPP}$ art. 496.1 (Italia).

${ }^{227}$ CPP art. 498 (Italia). 
ordenar la producción de las pruebas solicitadas por las partes, y que sólo bajo circunstancias excepcionales puede hacerlo de oficio ${ }^{228}$.

Segundo, la reforma también ha introducido varios mecanismos de simplificación y consenso, a través de los cuales la fiscalía y la defensa pueden negociar y acordar evitar los procedimientos regulares ${ }^{229}$. La introducción de estos mecanismos de simplificación ha sido justificada en términos de eficiencia ${ }^{230}$. Sin embargo, también son parte de esta amplia reforma del proceso penal italiano en el que las influencias culturales del modelo estadounidense - como sistema que ha simbolizado valores democráticos y eficiencia en la lucha contra el delito- han jugado un papel muy importante. Estos mecanismos han incluido la applicazione della pena su richiesta delle parti - aplicación de la pena a pedido de las partes ${ }^{231}$ - que suele ser llamado plea bargaining italiano, o simplemente pattegiamento, que significa "negociación" en italiano ${ }^{232}$.

Una diferencia crucial entre la introducción de los Absprachen alemanes y el patteggiamento es que éste último fue introducido por ley y como

${ }^{228}$ CPP arts. 190, 493.1, 495.1, 507 (Italia).

${ }^{229} \mathrm{CPP}$ arts. $438-64$ (Italia).

${ }^{230}$ Ver, por ejemplo, Vassalli, op. cit. nota 115, p. 7.

${ }^{231}$ Un precursor de esta institución fue la applicazione di sanzioni sostitutive su richiesta dell'imputato introducida en 1981 por L.vo 24 nov. 1981, n.689, Racc. Uff. 1981, vol. 13, 3657, publicada en Gazz. Uff., 30 nov. 1981, n.329. El alcance de este mecanismo fue muy limitado porque sólo se aplicaba a los delitos que tenían previsto hasta tres meses de prisión. Ver, por ejemplo, Pizzi \& Marafioti, op. cit., p. 22.

${ }^{232}$ Además del patteggiamento, la reforma de 1989 introdujo otros dos mecanismos que pueden ser comparados con el plea bargaining porque incluyeron potenciales negociaciones entre la fiscalía y la defensa, y requiririeron el consentimiento del imputado para su aplicación. La primera fue el procedimento per decreto. CPP arts. 459-64 (Italia) (similar a la orden penal alemana analizada en Herrmann, "Bargaining Justice" op. cit.). La segunda es el giudizio abbreviato. CPP arts. 438-43 (Italia) (en donde el acusado renuncia a su derecho al juicio y acepta ser enjuiciado en la audiencia preliminar). A cambio, recibe una reducción de un tercio de la sentencia regular. Inicialmente, este mecanismo exigía el consentimiento de la fiscalía para su aplicación, y por ende abría la puerta para las negociaciones entre la fiscalía y la defensa. Sin embargo, desde entonces, primero los tribunales y luego el parlamento, han limitado el consentimiento de la fiscalía como un requisito para su aplicación. Para un análisis de este proceso, ver Catalano, E. M., "Il Giudizio Abbreviato", en Amodio, E. \& Galantini, N. (eds.), Giudice unico e garanzie defensive, 117, 2000. Por limitaciones de espacio no voy a analizar estos dos mecanismos en el texto principal, pero deberían ser incluídos en un trabajo más amplio. 
De los trasplantes legales a las traducciones legales: la globalización del plea...

parte de una reforma que tenía un importante apoyo político. En este sentido, los traductores ${ }^{233}$ tuvieron mucha más libertad para decidir el grado de fidelidad con el plea bargaining estadounidense. Además, los reformistas italianos tenían un conocimiento muy sofisticado del sistema de justicia penal de Estados Unidos ${ }^{234}$, lo cual aunado a su libertad legislativa les permitió designar un mecanismo mucho más parecido al plea bargaining estadounidense que los Absprachen alemanes, sin dejar de considerar al mismo tiempo la estructura de sentido, las disposiciones internas y la estructura de poder inquisitivas preexistentes.

En el patteggiamento la defensa y la fiscalía pueden alcanzar un acuerdo sobre la pena y solicitarle al juez que la imponga ${ }^{235}$. A través de este acuerdo, la pena que regularmente correspondería puede ser reducida hasta un tercio siempre que la pena reducida no supere los cinco años de prisión ${ }^{236}$. Si al examinar el expediente del caso el juez considera que no

${ }^{233}$ El Código Procesal Penal de Italia fue elaborado por una Comisión designada por d.m. (decreto ministerial) del 3 de marzo de 1987, y estuvo compuesta por nueve profesores: Giandomenico Pisapia (Presidente), Delfino Siracusano (Vicepresidente), Ennio Amodio, Vincenzo Cavallari, Mario Chiavario, Oreste Dominioni, Vittorio Grevi, Guido Neppi Modona, y Mario Pisani; ocho jueces: Giancarlo Caselli, Enrico Di Nicola, Liliana Ferraro, Giuseppe La Greca, Giorio Lattanzi, Enrnesto Lupo, Vittorio Mele, y Piero Luigi Vigna; y un abogado: Giusepe Frigo. Ver Vassalli, op. cit. nota 115, p. 3.

${ }^{234}$ Por ejemplo, el profesor Ennio Amodio fue miembro de la Comisión Ministerial que diseñó las reformas y es, al mismo tiempo, un comparatista sofisticado. Ver, por ejemplo, Amodio, Ennio "Il Modello Accusatorio Statunitense e il Nuovo Processo Penale Italiano: Miti e Realtà della Giustizia Americana" en Amodio, E. and Bassiouni, M.C., (eds.), Il processo penale negli Stati Uniti d'America, Giuffrè, 1988.

${ }^{235}$ El patteggiamento está regulado en los artículos 444-48 del Código Procesal Penal de Italia. Para un análisis detallado de estos artículos, ver Cordero, F., Procedura penale, Giuffrè editore, 2000, $5^{\text {a }}$ ed. pp. 960-73 ( $\sin$ embargo, el profesor Cordero no incluye en su análisis a las reformas introducidas por la ley 134/2003, que analizo infra, nota 236). En el código original las partes podían solicitar la aplicación del mecanismo hasta el comienzo del juicio. La ley n. 479/1999 limitó este término hasta el final de la audiencia preliminar (con excepciones que no analizaré aquí), L.vo 16 dic. 1999, n.479, Racc. Uff. 1999, vol. 13, 6496, publicada en Gazz. Uff., 18 dic. 1999, n.296. La última reforma al patteggiamento introducida por la ley 134/2003 no modificó este aspecto y, como regla general, las partes pueden solicitar la aplicación de este mecanismo sólo hasta el final de la audiencia preliminar. Ver CPP art. 446.1 (Italia). Las partes no pueden solicitar la aplicación del patteggiamento luego de haber realizado sus conclusiones en la audiencia preliminar.

${ }^{236} \mathrm{CPP}$ art. 444.1 (Italia). El límite de los cinco años de prisión fue introducido por ley en 
hay motivos suficientes para absolver al acusado ${ }^{237}$ y entiende que el cargo y la pena son proporcionales al delito cometido, entonces aplicará la pena solicitada ${ }^{238}$.

Si bien es mucho más parecido al plea bargaining estadounidense que el Absprache alemán, lo cierto es que existen varias diferencias entre el patteggiamento y el plea bargaining estadounidense que reflejan, en parte, la ambivalencia de los traductores italianos hacia el propio mecanismo que introdujeron. Primero, el patteggiamento es más limitado en cuanto a su alcance y menos flexible. Sólo puede ser aplicado en casos donde la pena no supera los cinco años de prisión luego de la reducción, y la reducción de

junio de 2003. Ver L.vo 12 giu. 2003, n.134, art. 1, 1962, publicada en Gazz. Uff., 14 giu. 2003, n.136 [en adelante, ley 134/2003] (si la condena negociada es entre dos y cinco años de prisión, entonces ciertos delitos, como el terrorismo y el crimen organizado, quedan excluidos). Antes de esta última reforma, la condena que se negociaba no podía superar los dos años de prisión - luego de la correspondiente reducción - y por ende quedaba limitada a los delitos menores. La extensión del patteggiamento a más delitos se justificó en dos motivos: reducir la carga de trabajo del sistema de justicia penal y limitar la aplicación de los juicios completamente acusatorios a los delitos más graves. Ver Progetto di Legge-N. 1488, disponible en http:// www.camera.it/_dati/leg14/lavori/stampati/sk1500/ relazion/1488.htm (última visita del 25 de noviembre de 2003) (en los archivos de Harvard International Law Journal) (inicialmente proponiendo extender el pattegiamento a las condenas de hasta cuatro años de prisión luego de la reducción de un tercio). Se ha sugerido que la ley fue introducida por motivos políticos porque su art. 5 (que no se relaciona con la extensión del patteggiamento a las condenas acordadas de hasta cinco años de prisión) estableció que en los juicios que estuviesen pendientes, el acusado podía solicitar un receso de 45 días para evaluar si solicita la aplicación del patteggiamento. Este receso fue utilizado por Cesare Previti - una persona cercana a Silvio Berlusconi - en el caso Sme, en donde el propio Berlusconi estaba imputado, aun cuando el caso no pueda avanzar mientras esté en el ejercicio de sus funciones. Ver, por ejemplo, Berlusconi, processo sospeso sul "lodo" atti alla Consulta, véase el periódico La Repubblica (Italia), 30 de junio de 2003, en Politica, (en los archivos de Harvard International Law Journal). Por eso, se ha insinuado que este art. 5 en realidad fue introducido para obstaculizar este caso. Ver, por ejemplo, Vittorio Grevi, Doppio Blocco, DS MILANO, disponible en http://www.dsmilano.it/Pressroom/2003/07/ cor3_0701_grevi-doppio-blocco.htm. (última visita del 25 de noviembre de 2003) (en los archivos de Harvard International Law Journal).

${ }^{237} \mathrm{CPP}$ arts. 444.2, 129 (Italia).

${ }^{238} \mathrm{CPP}$ art. 444.2 (Italia). Si la condena que se acuerda es de hasta dos años de prisión, el juez la puede reemplazar por una pena sustitutiva como la semi-detención (para condenas de hasta dos años de prisión), libertad bajo vigilancia (para condenas de hasta un año de prisión) o una multa (para condenas de hasta seis meses de prisión). Ver ley 134/2003, supra nota 236 , p. $4.1(\mathrm{a})$. 
De los trasplantes legales a las traducciones legales: la globalización del plea...

la pena negociada por las partes no puede ser mayor que un tercio que la pena regular para el caso ${ }^{239}$. Además, al menos en la concepción originaria que tuvieron los reformistas, le negociación sólo podía referirse a la pena, no a los $\operatorname{cargos}^{240}$. La decisión de los traductores de fijar estos límites posiblemente refleje dos preocupaciones distintas. Por un lado, los traductores fueron ambivalentes hacia este mecanismo de negociación porque eran conscientes de los problemas ${ }^{241}$ que el plea bargaining estaba generando en términos del debido proceso en Estados Unidos ${ }^{242}$. Por el otro lado, eran conscientes de la existencia de actores legales con un conjunto de disposiciones internas inquisitivas ( $\mathrm{y}$ acostumbrados a una distribución inquisitiva de los poderes procesales) que podrían resistir a la institución traducida. Por ello decidieron introducirla sólo para delitos menores y limitar la práctica a la negociación de la pena ${ }^{243}$. Incluso cuando una reforma reciente ha expandido el número de delitos que se pueden negociar mediante el patteggiamento, lo cierto es que la práctica no se aplica a todos los delitos ${ }^{244}$.

Segundo, en el patteggiamento no hay guilty plea o una admisión explícita de culpabilidad por parte del acusado ${ }^{245}$. Cuando el acusado solicita el dictado de una sentencia condenatoria está renunciando a su derecho a un juicio e implícitamente puede estar admitiendo su culpabilidad. Sin embargo, el juez todavía puede absolver al acusado luego de valorar la prueba colectada en el expediente escrito y antes de aceptar el acuerdo ${ }^{246}$. Esta decisión de no introducir una admisión explícita de culpabilidad con el patteggiamento es otro reflejo de las preocupaciones por el debido proceso. Los redactores temían que una admisión de culpabilidad pudiese afectar a la presunción de inocen-

${ }^{239} \mathrm{CPP}$ art. 444.1 (Italia).

${ }^{240}$ Ver, por ejemplo, Pizzi \& Marafioti, op. cit., nota 220, p. 22. Sin embargo, existen indicios de que los acuerdos sobre los cargos habrían sido introducidos por los practicantes, y aceptados por los tribunales. Ver Cass. pen., sez. cin., 7 ott. 1998, n. 12743.

${ }^{241}$ Recuérdese que la reforma tenía una clara inspiración garantista (debido proceso).

${ }^{242}$ Sobre estas críticas en Estados Unidos, ver la bibliografía citada supra nota 170.

${ }^{243}$ Generalmente, los acuerdos sobre los cargos comprometen mucho más la verdad material que los acuerdos sobre la pena. Por lo tanto, estos últimos serían mucho más acceptables desde una perspectiva inquisitiva.

${ }^{244}$ Sobre esta reforma, ver CPP 444.1 (Italia).

${ }^{245}$ Ver, por ejemplo, Pizzi \& Marafioti, op. cit., p. 23.

${ }^{246} \mathrm{CPP}$ arts. 444.2, 129 (Italia). 
cia garantizada a todos los imputados por la Constitución italiana ${ }^{247}$. En este sentido, la ausencia de una admisión explícita de culpabilidad hace que el patteggiamento italiano sea más parecido a las negociaciones estadounidenses sobre el nolo contendere que sobre los guilty pleas.

Tercero, si el fiscal no acepta un acuerdo con el imputado, éste puede solicitarle al juez, al final del juicio, que examine los motivos dados por el fiscal en su rechazo y que le otorgue el beneficio de la reducción de un tercio de la pena ${ }^{248}$. Esta diferencia refleja la influencia del modelo de la investigación oficial en las disposiciones internas de los traductores ${ }^{249}$. Tal como se explicó anteriormente, la concesión de beneficios al imputado a cambio de admisiones de culpabilidad —en este caso admisiones implícitas de culpabilidad - no es desconocida en la estructura italiana. Lo que sí es extraño es la negociación de una pena que le quita poder al juez sobre la cuestión. Aun cuando el patteggiamento generalmente otorgue potestades a las partes a costa del juez, esta regla afirma que el juez sigue conservando cierta cuota de poder en la aplicación del mecanismo, y que no se trata sólo de un procedimiento de negociación, sino también un beneficio que el juez puede conceder al imputado.

Finalmente, la sentencia que se pronuncia bajo este procedimiento ${ }^{250}$ no tiene ningún efecto en el proceso civil y administrativo ${ }^{251}$, lo cual tam-

\footnotetext{
${ }^{247}$ Ver Pizzi \& Marafioti, supra nota 220, p. 23.

${ }^{248}$ CPP art. 448.1 (Italia).

${ }^{249}$ Como señalan Pizzi y Marafioti: "La intención del Código de Italia es que la reducción de la condena sea posible para todos los imputados que deseen negociar la condena, sea que el fiscal esté de acuerdo o no. Esta disposición refleja la tradicional desconfianza que tienen las jurisdicciones continentales europeas y latinoamericanas respecto a la discrecionalidad de la fiscalía, y el compromiso con el trato igualitario de los imputados - que los imputados reciban sentencias diferentes simplemente por un capricho del fiscal es un anatema para esas jurisdicciones -" Pizzi \& Marafioti, op. cit., nota 220, pp. 22-23.

${ }^{250} \mathrm{El}$ veredicto basado en un patteggiamento es considerado "equivalente a un veredicto de culpabilidad" (CPP art. 445.1-bis, Italia), pero no es como el veredicto dictado luego de un juicio regular. Esto explica los efectos más limitados que tienen el veredicto y la sentencia basada en el patteggiamento y demuestra, nuevamente, la desconfianza y ambivalencia de los reformistas hacia este mecanismo.

${ }^{251} \mathrm{CPP}$ art. 445.1-bis (Italia). La única excepción a esta regla es que la sentencia acordada constituye res judicata para los procedimientos disciplinarios ante las autoridades públicas. Ver CPP arts. 445.1-bis, 653.1- bis (Italia).
} 
De los trasplantes legales a las traducciones legales: la globalización del plea...

bién hace que el patteggiamento se encuentre más cerca del nolo contendere estadounidense que del plea bargain. Esta limitación de los efectos legales del mecanismo también refleja la ambivalencia de los traductores a raíz de sus preocupaciones vinculadas con el debido proceso, y la influencia del modelo de la investigación en sus disposiciones internas.

Pero a pesar de su ambivalencia, la traducción italiana del plea bargaining es fidedigna al mecanismo estadounidense original, en cuanto que se trata de un procedimiento a través del cual la fiscalía y la defensa pueden negociar activamente las penas y se le asigna al juez una posición relativamente pasiva. En este sentido la adopción del patteggiamento ha tenido desde el principio un potencial efecto "americanizante"; si fuese aceptado e internalizado por los actores legales italianos como un mecanismo de negociación, y si fuese acompañado por otras reformas acusatorias, el patteggiamento tiene el potencial para movilizar las prácticas procesales penales italianas hacia el modelo de la disputa, en reemplazo de las disposiciones internas de los actores legales y la estructura de interpretación y sentido predominantemente inquisitivas, así como también modificar la distribución de los poderes procesales.

Por ello no resulta sorprendente que haya habido cierta resistencia a este nuevo procedimiento, tanto por parte de la doctrina como de los tribunale ${ }^{252}$. La reacción más importante de los tribunales hasta ahora ha sido la decisión 313/1990 del Tribunal Constitucional de Italia dictada el año posterior a que el nuevo código italiano introdujera el patteggiamento ${ }^{253}$. En esta decisión, y luego de afirmar repetidamente que las potestades de control del juez sobre el acuerdo no eran una mera formalidad ${ }^{254}$, el Tribunal Constitucional sostuvo que el art. 442.2 del Código Procesal Penal,

\footnotetext{
${ }^{252}$ Entre las críticas por parte de la doctrina, ver Ferrajoli, op. cit., nota 66; y Ferrua, op. cit. Ambas críticas tienen sus orígenes en su defensa de la subestructura de la investigación oficial porque los dos señalan el modo en que los mecanismos de negociación comprometen la verdad real. Sin embargo, estas críticas se inspiran en preocupaciones de debido proceso puesto que ambos autores consideran a la verdad - y al rol cognitivo del juez - como una protección para el imputado. Para una defensa muy sofisticada de esta concepción (garantista) del proceso penal, ver Ferrajoli, op. cit.

${ }^{253}$ Corte cost., 26 giu. 1990, n.313, 96 Racc. uff. corte. 1990, 89.

${ }^{254}$ Ver, por ejemplo, id. pp. 97-98.
} 
que regulaba el patteggiamento, era inconstitucional porque no le daba expresamente al juez el poder de controlar la congruencia entre la condena acordada por las partes y la gravedad del delito, y así le impedía hacer cumplir el art. 27.3 de la Constitución de Italia que establece que la finalidad de la pena es la rehabilitación del condenado ${ }^{255}$. De esta manera se intentó reafirmar e incrementar los poderes del juez con respecto a las partes en relación al patteggiamento.

Pero a pesar de esta reacción los actores legales italianos han utilizado ampliamente al patteggiamento. Entre 1990 y 1998 la cantidad de casos resueltos a través de este procedimiento en la pretura (jurisdicción para delitos menores) fue entre 17 y $21 \%$, y en el caso del tribunale (la jurisdicción para todos los delitos excepto los más serios) fue entre 34 y $42 \%{ }^{256}$. Ahora que la aplicación del patteggiamento ha sido extendida a los delitos más serios ${ }^{257}$ es probable que los actores legales lo usen de forma aún más amplia.

Esto indica que el modelo de la disputa, entendido como una estructura de interpretación y sentido, ha sido aceptado e internalizado, al menos hasta cierto punto, por un gran número de actores legales italianos. Además, y como consecuencia de la reforma del código procesal italiano que comenzó en 1989, hay otros indicadores de que el modelo de la disputa tiene una presencia sustancial en los procedimientos italianos. Me refiero aquí a la posibilidad de que la fiscalía y la defensa realicen su propia investigación preliminar, al hecho de que el juicio se organice como el caso de la fiscalía y el caso de la defensa, y a la introducción del examen directo y cruzado, como ya se mencionó anteriormente.

Sin embargo, esto no significa que el modelo de la investigación oficial no tenga una presencia importante en el procedimiento penal italiano y en las disposiciones individuales de un gran número de actores legales. Muchos jueces italianos, por ejemplo, todavía consideran que tienen el

${ }^{255}$ Id. pp. 102-05.

${ }^{256}$ Para información estadística de 1990 y 1991, ver Istituto Centrale di Statistica, Statistiche giudiziarie; de 1992 a 1998, ver Istituto Centrale di Statistica, Statistiche giudiziarie penali. No incluyo las estadísticas de 1989 porque el número total de casos de la muestra es mucho menor para ese año que para los otros. 
De los trasplantes legales a las traducciones legales: la globalización del plea...

deber de asegurar que la verdad prevalezca, y por lo tanto participan activamente en el proceso de acreditación de los hechos ${ }^{258}$. Asimismo, tanto los fiscales como los jueces italianos siguen siendo parte del poder judicial y se forman juntos. De este modo, muchos fiscales italianos aún se consideran a sí mismos, y así son considerados por los jueces, como magistrados cuyo rol es investigar la verdad y no como meras partes de una disputa ${ }^{259}$.

Un análisis en detalle de estas luchas particulares entre el modelo de la disputa y el de la investigación oficial está más allá de los límites de este artículo. El propósito de esta sección ha sido mostrar cómo el plea bargaining estadounidense ha sido traducido en el sistema italiano y los tipos de transformaciones que esta traducción puede estar produciendo. Desde la perspectiva de la discusión sobre la tesis de la "americanización", no quedan dudas que el patteggiamento, y las otras reformas, han promovido al modelo de la disputa como estructura de interpretación y sentido. Podría decirse que no hay ningún otro país continental europeo o latinoamericano en donde esta estructura haya alcanzado un estatus tan importante ${ }^{260}$. En este sentido, el desarrollo de la reforma de 1989 parece haber puesto a Italia en una encrucijada entre el sistema acusatorio y el inquisitivo.

\section{E1 "plea bargaining" argentino}

De los cuatro sistemas examinados en este artículo, el plea bargaining argentino ha sido la traducción más fidedigna al plea bargaining estadounidense. No obstante, esta reforma representa una de las muy pocas realizadas en Argentina en la dirección del sistema acusatorio ${ }^{261}$. Dado que la estructura de interpretación y sentido, las disposiciones internas y la distribución de poderes procesales inquisitivos que existían anteriormente en el sistema argentino siguen siendo predominantes, es muy poco probable

${ }^{258}$ Ver, por ejemplo, Grande, op. cit., en nota 32, pp. 250-51.

${ }^{259}$ Con respecto a esta y otras resistencias que resultan de la estructura de la investigación oficial, ver Grande op. cit.

${ }^{260}$ Nota de actualización: esta afirmación se refiere al tiempo en que fue escrito este artículo en 2002-3.

${ }^{261}$ Nota de actualización: la afirmación se refiere al CPPN, Ley 23.984 y sus modificaciones. 
que esta reforma acusatoria, por sí sola, vaya a "americanizar" el proceso penal argentino en el sentido de promover sus prácticas y cultura procesal penal en la dirección del modelo de la disputa.

En junio de 1997 la Argentina incorporó el llamado procedimiento abreviado $^{262}$ en su Código Procesal Penal de la Nación ${ }^{263}$ a fin de acelerar los procesos judiciales y reducir la carga de trabajo de los tribunales ${ }^{264}$. Este mecanismo parece haber sido adoptado principalmente por motivos pragmáticos más que como resultado de profundas influencias culturales del sistema estadounidense, aunque estas influencias, de hecho, estuvieron presentes ${ }^{265}$. En todo caso, el plea bargaining estadounidense ha sido una fuente importante para el desarrollo de la práctica argentina. Según

${ }^{262}$ El procedimiento abreviado también es conocido como juicio abreviado. Ver CPP art. 431 bis (Arg.).

${ }^{263}$ Argentina es un estado federal compuesto por 23 provincias. Existe un único Código Penal para todas las jurisdicciones. Pero cada provincia tiene su propio código procesal penal y su propio sistema de tribunales. El Código Procesal Penal de la Nación regula el procedimiento de los tribunales federales y de la Justicia Nacional en lo Criminal y Correccional de la ciudad de Buenos Aires. En este artículo me concentraré en este procedimiento.

${ }^{264}$ Además de estos dos objetivos, durante las audiencias en el Congreso de la Nación con respecto a este instituto también se consideró reducir el número de detenidos con prisión preventiva, reducir el costo de los juicios, racionalizar el uso de los recursos del proceso penal y permitirles a los acusados la oportunidad de recibir una reducción en sus sentencias. Ver "Wasylyszyn, M.A.," Trib. Oral Crim. no. 20, 8a, en Cuadernos de doctrina y jurisprudencia penal, 1998, p. 623, 628 (en donde se describe la intervención del diputado José I. Cafferata Nores en el debate parlamentario del 23 de octubre de 1996). Ver también Cafferata Nores, J. I., Cuestiones actuales sobre el Proceso Penal, Editores del Puerto, 1998, $2^{\mathrm{a}}$ ed., p. 143.

${ }^{265} \mathrm{El}$ sistema de justicia penal estadounidense ha tenido una profunda influencia cultural sobre los precedentes de la Corte Suprema de Justicia de la Nación de Argentina con respecto a los derechos constitucionales en el proceso penal (detención y requisa, derecho contra la autoincriminación forzada, regla de exclusión, doctrina del fruto del árbol envenenado, etc.). Para un análisis de este tipo de decisiones de la Corte Suprema argentina, ver en general Carrió,. A. D., Garantías constitucionales en el proceso penal, 3a edición, Hammurabi, 1997. Con respecto a la influencia de los precedentes de la Corte Suprema de EE.UU. sobre la Corte Suprema de Argentina, ver Suárez Anzorena, C, I., Transnational Precedents: The Argentinean Case, 1998, pp. 26-40 (tesis de maestría inédita, Harvard Law School) (en los archivos de Harvard Law School Library). Sin embargo, el sistema de justicia penal estadounidense no ha sido tan influyente como fue con el caso italiano. El sistema italiano ha importado partes sustanciales del proceso penal estadounidense en vez de sólo algunas piezas selectas. 
De los trasplantes legales a las traducciones legales: la globalización del plea...

el procedimiento abreviado, la fiscalía y la defensa pueden alcanzar un acuerdo sobre la condena en cualquier momento entre el requerimiento de elevación a juicio, al finalizar la instrucción, y la designación de audiencia para el debate ${ }^{266}$. Esta condena negociada no puede superar los seis años de prisión ${ }^{267}$. Como parte del acuerdo, el acusado debe admitir la existencia del hecho y su participación tal como se describieron en el requerimiento de elevación a juicio ${ }^{268}$. El tribunal de juicio puede rechazar el acuerdo si considera que es necesario producir nuevas pruebas o discrepa con la calificación legal ${ }^{269}$. Pero si el tribunal acepta el acuerdo debe dictar una condena con base en la prueba colectada en el expediente escrito ${ }^{270}$. El tribunal todavía puede absolver al acusado, pero si lo condena no puede imponerle una pena mayor que la que acordaron las partes ${ }^{271}$.

De todas las traducciones legales analizadas en este artículo, el procedimiento abreviado argentino parece ser el más fiel al plea bargaining estadounidense, o más específicamente, al acuerdo sobre la pena estadounidense (sentencing bargaining) ${ }^{272}$. La fiscalía y la defensa tienen roles activos en la negociación sobre la pena y la admisión de culpabilidad, mientras que el rol del tribunal se limita básicamente a un control formal. Además, el procedimiento abreviado incluye una admisión de culpabilidad del acusado similar a la del guilty plea. Y como las partes pueden acordar una pena de hasta seis años, el procedimiento abreviado se aplica a algunos de los delitos más graves, aunque no a todos ${ }^{273}$.

Pero, de todos modos, existen diferencias entre el procedimiento abreviado y el plea bargaining estadounidense que muestran el modo en que las decisiones tomadas por los traductores argentinos, así como la estructura de interpretación y sentido y la distribución de poderes procesales inquisi-

\footnotetext{
${ }^{266}$ CPP art. 431 bis. 1 (Arg.).

${ }^{267} \mathrm{Id}$.

${ }^{268} \mathrm{CPP}$ art. 431 bis. 2 (Arg.).

${ }^{269} \mathrm{CPP}$ art. 431 bis. 3 (Arg.).

${ }^{270} \mathrm{CPP}$ art. 431 bis. 5 (Arg.).

${ }^{271} \mathrm{Id}$.

${ }^{272} \mathrm{El}$ plea bargaining estadounidense fue una fuente muy importante para el desarrollo del procedimiento abreviado. Ver "Wasylyszyn, M.A.", op. cit., en nota 262, pp. 628-29.

${ }^{273}$ Por ejemplo, el procedimiento puede ser aplicado para los homicidios culposos, violación y robos agravados.
} 
tivos preexistentes transformaron esta práctica ${ }^{274}$. Primero, existe una limitación temporal respecto de cuándo las partes pueden llegar a un acuerdo, lo cual hace que todo el procedimiento sea menos flexible ${ }^{275}$. Segundo, en el procedimiento abreviado el juez todavía puede absolver al acusado ${ }^{276}$. En consecuencia, la admisión de culpabilidad no es entendida exactamente como un guilty plea en los Estados Unidos, sino como una confesión que puede ser desestimada por el tribunal, con lo cual expone la influencia de la estructura de sentido inquisitiva preexistente sobre la práctica. Tercero, el tribunal tiene que respetar, como límite máximo, la pena acordada por las partes ${ }^{277}$. Este límite no siempre rige para los acuerdos sobre la pena estadounidenses, aunque la mayoría de los jueces lo respetan de facto ${ }^{278}$.

${ }^{274}$ Las dos personas que introdujeron el procedimiento abreviado en Argentina fueron los profesores Julio B. J. Maier (quien incluyó un mecanismo similar en su proyecto de Código Procesal Penal de la Nación de 1986, que no fue aprobado por el Congreso, y en el Código Procesal Penal Modelo para Iberoamerica) y José I. Cafferata Nores (profesor universitario, ex ministro de justicia de la provincia de Córdoba y miembro de la Cámara de Diputados de la Nación cuando se aprobó el procedimiento abreviado). Ambos concibieron a este instituto sólo para casos menores. Por ejemplo, en el art. 371 de su proyecto de Código Procesal Penal de la Nación, el prof. Maier lo consideró para casos en los cuales la condena no fuese superior a un año de prisión. Maier, J., "El proyecto de Código Procesal Penal de la Nación: presentación de Julio B. Maier, Exposición de motivos, texto completo del proyecto, p. 764", Cuadernos de la Revista Doctrina Penal, Series No.1, 1987. Creían que este mecanismo sería útil para administrar los casos menores en forma más rápida, pero también tenían desconfianza puesto que eran conscientes de que implicaba una concepción completamente diferente del proceso penal. Por ejemplo, Maier claramente advirtió que el mecanismo implicaba una concepción de la verdad más consensual y relativa. Ver Maier, J. B. J., "Mecanismos de Simplificación del Procedimiento Penal", en Cuadernos de doctrina y jurisprudencia penal, 1998, op. cit., en nota 267, p. 433, 435. La desconfianza de Maier y Cafferata Nores hacia este instituto también se basaba en preocupaciones sobre el debido proceso puesto que estaban al tanto de las críticas que este tipo de acuerdos estaban generando en Estados Unidos y en otros lugares. De todas maneras, y a pesar de sus intentos por introducir el mecanismo sólo para casos menores, el Congreso de Argentina extendió su aplicación a delitos relativamente graves.

${ }^{275}$ Ver CPP art. 431 bis. 1 (Arg.).

${ }^{276} \mathrm{CPP}$ art. 431 bis. 5 (Arg.) dice que una vez que la fiscalía y la defensa han alcanzado un acuerdo, el tribunal todavía debe dictar su sentencia. Por lo tanto, técnicamente es posible que el tribunal dicte una absolución. Sin embargo, la práctica muestra que generalmente ello no ocurre y los tribunales dictan la condena.

${ }^{277}$ Id. 
De los trasplantes legales a las traducciones legales: la globalización del plea...

Cuarto, en un caso con más de un acusado sólo se puede aplicar el mecanismo si es aceptado por todos ${ }^{279}$. Esto muestra una desconfianza hacia el mecanismo desde una perspectiva del debido proceso $^{280}$.

Pero, más allá de estas diferencias, el procedimiento abreviado es una traducción fiel del plea bargaining estadounidense, y como tal asume el modelo de la disputa en cuanto a que ambas partes controlan el caso mientras que el juez tiene un papel relativamente pasivo. En este sentido, el procedimiento abreviado puede ser considerado como un Caballo de Troya para el modelo de la disputa en el modelo inquisitivo argentino de la investigación oficial ${ }^{281}$. Si los actores legales argentinos aceptaran e internalizaran este mecanismo, entonces la reforma podría "americanizar" (o tornar más acusatorio) el proceso penal argentino.

El modelo de la investigación oficial siempre ha sido predominante en el proceso penal argentino ${ }^{282}$. Por ello no es sorprendente que desde un sector de la doctrina se haya criticado fuertemente la introducción de un mecanismo tan claramente inspirado en el modelo de la disputa ${ }^{283}$. Sin embargo, en general, los abogados defensores, fiscales y jueces lo han aceptado y utilizado ${ }^{284}$. Por ejemplo, en el primer semestre de 2000, el 22\%

Scott \& Stuntz, supra nota 170, pp. 1953-57.

${ }^{279} \mathrm{CPP}$ art. 431 bis. 8 (Arg.).

${ }^{280} \mathrm{La}$ exigencia de que todos los imputados tengan que aceptar los acuerdos puede haber pretendido evitar que se utilice al procedimiento abreviado con fines de investigación, i.e., para hacer que un imputado declare en contra de otro.

${ }^{281}$ Para un análisis sobre los posibles efectos de la incorporación del procedimiento abreviado en Argentina, ver Langer, supra nota 23, p. 124.

${ }^{282}$ Para una descripción en inglés del sistema procesal penal federal de Argentina, ver Carrio, A. D. y Garro, A. M,. Argentina, en Bradley, C.M., Criminal Procedure: a Worldwide Study, 1999, p. 3

${ }^{283}$ Ver, por ejemplo, D’Albora, F. J., "El proceso penal y los juicios abreviados", en Cuadernos de doctrina y jurisprudencia penal, 1998, op. cit., en nota 262, p. 457, 463; Schiffrin, L. H., "Corsi e ricorsi de las garantías penales en la Argentina", en Cuadernos de doctrina y jurisprudencia penal, op. cit., en nota 267, p. 481, 484. Como en el ejemplo de Italia, gran parte de esta crítica también se basaba en cuestiones de debido proceso puesto que varios autores conocían las críticas que el plea bargaining había recibido en Estados Unidos al respecto.

${ }^{284}$ La resistencia contra el procedimiento abreviado ha provenido principalmente de unos pocos jueces de algunos tribunales de juicio. En Argentina, los tribunales de juicio para los delitos graves y medios están compuestos por tres jueces. Algunas opiniones en disidencia de los jueces de estos tribunales han dicho que el procedimiento abreviado es inconstitucional porque la realización de un juicio verdadero es una condición necesaria para que se pueda dictar una 
de los casos ante los juzgados correccionales de la ciudad de Buenos Aires fueron resueltos a través del procedimiento abreviado, y el 52\% de los casos ante los tribunales orales en lo criminal de la misma jurisdicción fueron resueltos de la misma manera ${ }^{285}$. Es posible que una de las principales razones de esta amplia aceptación se deba a fuertes incentivos externos: entre 1990 y 2000 el número de casos que ingresó en el sistema de justicia penal de la ciudad de Buenos Aires aumentó de 61.203 a 191.755 (313\%) $)^{286}$. En una situación semejante cualquier mecanismo para resolver los casos penales en forma rápida hubiese sido bienvenido, aun cuando coexistiere en tensión con la estructura de interpretación y sentido imperante, las disposiciones internas y la distribución de poderes procesales.

Además de la introducción del procedimiento abreviado han existido otras dos tendencias que podrían movilizar al procedimiento penal argentino en la dirección del modelo acusatorio de la disputa. Primero, la regla de la persecución penal obligatoria no se aplicó en el juicio durante años ${ }^{287}$. Segundo, desde 1994 ha existido una clara diferenciación institucional entre

condena penal, el cual no puede ser reemplazado por un acuerdo entre la fiscalía y la defensa. Ver, por ejemplo, "Dos Santos Amaral, M.," Trib. Pen. Económico no. 3, Cuadernos de doctrina y jurisprudencia penal, op. cit. en nota 262, p. 613; "Wasylyszyn, M.A.," op. cit.; “Osorio Sosa, A.," Trib. Oral Crim. no. 23, Cuadernos de doctrina y jurisprudencia penal, supra nota 262, p. 636. Además, algunos tribunales de juicio también han sostenido que el procedimiento abreviado es inconstitucional, ver, por ejemplo, “Yunez, R.D.", Trib. Oral Crim. Fed. [1999-C] L.L. 335.

${ }^{285}$ Informe anual al Congreso de la Nación, Ministerio Público Fiscal de la República Argentina, Procuraduría general de la Nación, 2000, pp. 297-98, 285- 86. Estas estadísticas se refieren a la etapa de juicio. En la etapa de la instrucción esta práctica es totalmente insignificante, por ende no está incluida aquí.

${ }^{286}$ Ver Evolución de Hechos Delictuosos --1990 a 1999-- Total País y Por Provincia, Ministerio de Justicia, Seguridad y Derechos Humanos de la Nación Argentina en http:// www.jus. gov.ar/polcrim/InfoDecada/infosnic2C33A.pdf (última visita del 2 de diciembre de 2003) (en los archivos de Harvard International Law Journal).

${ }^{287}$ Ver, por ejemplo, “Tarifeño, F.” CSJN [1995-B] L.L. 32; “García, J.A.,” CSJN [1995-B] L.L. 31; "Cattonar, J.P.", CSJN, [1996-A] L.L. 67. Para un breve análisis de estas decisiones, ver Maier, J. B.J. \& Langer, M., “Acusación y Sentencia”, en Nueva Doctrina Penal, 1996/B, p. 617. Sin embargo, la Corte Suprema de Justicia de la Nación revocó esas decisiones sobre esta cuestión, y la regla de la persecución penal obligatoria actualmente se aplica en el juicio. Ver "Marcilese, P.J.," CSJN [2002- E] L.L. 719. Nota de actualización: Después de la publicación de este artículo en inglés, la Corte Suprema argentina retornó a su posición previa y el principio de obligatoriedad de la acción penal no se aplica en el juicio oral. 
De los trasplantes legales a las traducciones legales: la globalización del plea...

los fiscales y los jueces que puede contribuir a distinguir ambos roles dentro del proceso penal, una condición que hace posible al modelo de la disputa ${ }^{288}$. Sin embargo, es importante no exagerar el significado de estos cambios, incluyendo la introducción del procedimiento abreviado. Prácticamente estas han sido las únicas reformas llevadas a cabo que pueden conducir al sistema legal argentino en la dirección del modelo de la disputa. En el resto de las prácticas procesales argentinas de la jurisdicción federal y la justicia nacional en lo criminal y correccional de la ciudad de Buenos Aires, siguen predominando la estructura de interpretación de sentido, las disposiciones internas y la distribución de poderes procesales inquisitivas ${ }^{289}$. Por ejemplo, se sigue viendo con mucha claridad el modelo de la investigación oficial en el rol que tiene el juez, que todavía está a cargo de la investigación preliminar o instrucción ${ }^{290}$, y en el que tiene el tribunal del juicio, puesto que decide qué pruebas serán producidas y en qué orden ${ }^{291}$, y tiene un papel activo en el interrogatorio de los testigos, incluyendo a los peritos ${ }^{292}$. Por lo tanto, y a pesar de las similitudes entre el procedimiento abreviado y los acuerdos sobre la pena estadounidenses, el modelo de la investigación oficial es mucho más predominante en Argentina que en Italia. Y si bien el modelo de la disputa ha aparecido en el procedimiento penal federal de Argentina, lo cierto es que su presencia todavía es menor.

Desde la perspectiva de la tesis de la "americanización" se puede decir que el proceso penal federal argentino no ha sido "americanizado", por el contrario, la concepción del proceso penal como una investigación oficial

${ }^{288}$ Ver Constitución Argentina, art. 120, modificada por ley 24.309, 23 de agosto de 1994, B.O. (Arg.) (establece que el Ministerio Público no es parte del Poder Ejecutivo ni del Judicial, sino un órgano de gobierno extrapoder).

${ }^{289}$ Muchas otras jurisdicciones argentinas han introducido varias reformas acusatorias en sus procesos penales durante la década de los noventa, incluyendo a las provincias de Buenos Aires (1997) y Córdoba (1991). Sin embargo, estas reformas están más allá del alcance de este artículo. Estas reformas han eliminado la figura del juez de instrucción en la mayoría de los casos y han puesto al fiscal a cargo de la investigación durante la etapa preliminar, ver, por ejemplo, Guariglia y Bertoni, op. cit. en nota 117, pp. 66-67. Pero incluso en estas jurisdicciones el modelo de la investigación oficial sigue siendo predominante, y, por lo tanto, estas reformas no modifican mis principales conclusiones.

${ }^{290}$ Ver CPP art. 26 (Arg.).

${ }^{291}$ Ver CPP art. 356 (Arg.).

${ }^{292}$ Ver CPP art. 389 (Arg.). 
sigue siendo abrumadora. La principal razón parecería ser que pese a que la traducción del plea bargaining estadounidense ha sido bastante fidedigna a su texto originario, de todos modos no se realizaron suficientes reformas que tuviesen un posible efecto acusatorio. Las diferencias entre las culturas acusatoria e inquisitiva son tan profundas que el efecto "americanizante" de una única reforma acusatoria, como la del procedimiento abreviado, probablemente sea neutralizada con facilidad. El caballo de madera ha atravesado los muros del procedimiento penal argentino, pero los soldados que llevaba en su interior no fueron suficientes para tomar Troya, o al menos una parte de la ciudad. Sólo el tiempo dirá si aparecerán nuevos Caballos de Troya en el futuro ${ }^{293}$.

${ }^{293}$ Nota de actualización: el nuevo “Código Procesal Penal de la Nación Argentina”, Ley 27.063, aprobado en diciembre de 2014, tiene una estructura mucho más acusatoria, pero todavía no ha entrado en vigor. Según el plan anunciado por las autoridades, será implementado primero en la justicia federal de las provincias de Jujuy y Salta. [Nota de la Editora: la ley referida fue ulteriormente reformada en diciembre de 2018] 
De los trasplantes legales a las traducciones legales: la globalización del plea...

\section{El "plea bargaining" francés ${ }^{294}$}

El "plea bargaining" francés, o composition, se parece muy poco al modelo estadounidense. Este mecanismo difiere de la práctica estadounidense en cuanto a que se trata más de una herramienta para evitar que los casos ingresen al procedimiento penal formal, que para resolverlos una vez que ya ingresaron. Por ende, esta traducción del plea bargaining seguramente no vaya a modificar al proceso penal francés - predominantemente inquisitivo- en la dirección del sistema acusatorio estadounidense.

A fines de junio de 1999 se introdujo la composition en los arts. 41-2 y 41-3 del Código Procesal Penal de Francia ${ }^{295}$ con la finalidad de reducir la

${ }^{294}$ El ministro de justicia francés, Dominique Perben, ha presentado un proyecto de ley que todavía está pendiente de tratamiento por el parlamento (a partir del 24 de octubre de 2003), en donde propone reformas sustanciales al proceso penal. Ver Projet de loi portant adaptation de la justice aux évolutions de la criminalité en http:// www.assemblee-nat.fr/12/pdf/projets/ p10784.pdf (última visita del 3 de diciembre de 2003). Este proyecto de ley, conocido como la "ley Perben" ("projet de loi Perben"), fue presentado como un intento de "adaptar la administración de justicia a la evolución de la criminalidad”. Esta propuesta incluye la posibilidad del acusado de declararse culpable [pleading guilty] por delitos que tienen previsto hasta cinco años de prisión. Como se trata de una propuesta que no ha sido aprobada aun, no la analizaré en detalle en este artículo. Nota de actualización: este proyecto fue adoptado por la ley "Perben II" del 9 de marzo de 2004. Conf. Art. 495-7 a 495-16 del CPPF. Otro intento por introducir un mecanismo similar al guilty plea tuvo lugar a fines de la década de los ochenta y principio de los noventa, cuando una comisión del Ministerio de Justicia de Francia generalmente conocida como la Comisión Delmas-Marty - propuso la introducción de un mecanismo similar a la declaración de culpabilidad estadounidense, aunque específicamente rechazaba la introducción del plea bargaining. Ver Delmas-Marty, M., "Rapport sur la mise en état des affaires pénales", Commission Justice pénale et droits de l'Homme (1991). Dos motivos por los cuales los actores legales franceses rechazaron estas propuestas fueron que las veían como foráneas y que tenían un apego al sistema inquisitivo existente ver Salas, D., "La justice entre les deux corps de la démocratie", en Salas, D. (ed.), La justice, une révolution démocratique, Desclée de Brouwer, 2001. Para un breve análisis de la propuesta de la Comisión Delmas-Marty con respecto a los guilty pleas, ver Tulkens, op. cit. en nota 178, p. 672.

${ }^{295}$ Ley No. 99-515 del 23 de junio de 1999, J.O., 24 de junio de 1999, p. 9207 . El antecedente de la composition pénale era la injonction pénale aprobada por ley del 22 de diciembre de 1994. Sin embargo, el 2 de febrero de 1995, el Tribunal Constitucional (Conseil Constitutionnel) declaró la inconstitucionalidad de la injonction por considerar que violaba la presunción de inocencia y que le otorgaba a los fiscales potestades para juzgar los casos e imponer sanciones que deberían estar a cargo de los tribunales, ver MERLE \& VITU, supra nota 109, p. 396. 
carga de trabajo de los tribunales ${ }^{296}$. Este mecanismo ha sido considerado un homólogo del plea bargaining estadounidense, puesto que deja lugar a la negociación entre la fiscalía y la defensa ${ }^{297}$. Según la composition, antes del comienzo formal del procedimiento la fiscalía puede ofrecer al imputado la opción de no ejercer la acción penal a cambio de una admisión de culpabilidad y el cumplimiento de una condición, como el pago de una multa, la entrega de los objetos utilizados en el delito (u obtenidos en su comisión), la renuncia a su licencia para conducir o cazar, la realización de tareas comunitarias y/o la reparación del daño ocasionado a la víctima ${ }^{298}$. Si el imputado acepta el ofrecimiento, la fiscalía solicita que sea homologado por el juez ${ }^{299}$. Si el imputado no lo acepta, o no cumple con las condiciones del acuerdo, la fiscalía simplemente puede iniciar el procedimiento formal, ejerciendo la acción penal ${ }^{300}$.

${ }^{296}$ Ver Conte, Philippe, Patrick Maistre Du Chambon, and Patrick Maistre du Chambon. Procédure pénale. Masson: A. Colin, 2002, pp. 3-4 (3d ed. 2001); Merle y Vitu, op. cit., en nota nota 109, p. 395.

${ }^{297}$ Merle y Vitu, op. cit., p. 396; Cedras, op. cit., pp. 156-57; Magendie, J. C., "Laméricanisation du droit ou la création d'un mythe", en Archives de Philosophie du Droit, vol. 45, 2001, p. 13, 18-19. Existen otros mecanismos en el proceso penal francés que dejan lugar para las negociaciones entre la fiscalía, el acusado e incluso la víctima y el juez, tales como la médiation pénale, correctionnalisation y comparution immédiate. Ver Tulkens, op. cit., pp. 660-61, 672-73. Estos no serán analizados aquí y, hasta donde llega mi conocimiento, no se han inspirado en el plea bargaining, ni considerado análogos. Se pueden consultar varios análisis sobre el rol que tiene la negociación en el derecho penal y en otras ramas del derecho en los artículos incluídos en Gérard, Philippe. Droit négocié, droit imposé?. Presses de l'Université Saint-Louis, 1996.

${ }^{298}$ Código Procesal Penal. art. 41-2 (2002) (Francia). Para un análisis detallado de este mecanismo, ver Ministére de la Justice. Circulaires de la direction des Affaires criminelles et des Grâces, Bulletin Officiel du Ministére de la Justice, vol. 83, 2001. Disponible en http:// www.justice.gouv.fr/actua/bo/dacg83c.htm (última visita del 25 de noviembre de 2003). La propuesta no se puede realizar cuando el imputado está detenido. El fiscal o un asistente tiene que informar al imputado de su derecho a ser asistido por un abogado.

${ }^{299}$ Tanto el imputado como la víctima pueden solicitar al juez una audiencia antes de que decida sobre el acuerdo. Sin embargo, esta audiencia no se realiza si no es específicamente solicitada. Ver CPP. art. 41-2 (Francia). Como la composición fue introducida como una forma de tratar de manera más efectiva los casos por delitos menores, se considera que la audiencia con el imputado y/o la víctima antes de validar el acuerdo es excepcional. Ministére de la Justice, op. cit. 296, p. 96.

${ }^{300}$ Mientras se cumplen las condiciones del acuerdo se suspende el transcurso del plazo para la prescripción de la acción. 
De los trasplantes legales a las traducciones legales: la globalización del plea...

La composition sólo se puede aplicar a ciertos delitos específicamente enumerados en el código francés, tales como lesiones simples, amenazas, robo simple, daños, calumnias e injurias, maltrato de animales, posesión de ciertas armas o conducción en estado de intoxicación, entre otros ${ }^{301}$. Además, su aplicación se limita a aquellos casos que no revisten gravedad ${ }^{302}$.

Como surge con claridad de esta descripción, sólo es posible referirse a la composition como un "plea bargaining" de manera sumamente laxa ${ }^{303}$. Esto pone de manifiesto, una vez más, lo inadecuada que es la idea del trasplante legal para captar este fenómeno de la circulación de ideas y prácticas legales. Ciertamente existen similitudes entre el procedimiento del plea bargaining estadounidense y la composition: ambos incluyen negociaciones entre la fiscalía y el imputado, y éste último tiene que admitir su culpabilidad como parte del acuerdo. Sin embargo, aquí terminan las semejanzas.

Las diferencias entre el plea bargaining estadounidense y la composition son significativas. Primero, mientras que la aplicación del plea bargaining reduce la duración de los procedimientos penales regulares en el sentido de que no es necesario el juicio para establecer la culpabilidad o inocencia,

${ }^{301}$ CPP art. 41-2 (Francia); Ministére de la Justice, op. cit., pp. 69-70. Nota de actualización: esta lista fue ampliado por la "ley Perben" como es descrito infra nota 300.

${ }^{302}$ Ministére de la Justice, p. 68 . Además de proponer la introducción de un nuevo mecanismo similar a la declaración de culpabilidad estadounidense (reconnaissance préalable de culpabilité), ver Perben, infra nota 301, la "ley Perben" también propone una extensión de la composition a todos los delitos de hasta cinco años de prisión. Ver Dominique Perben, Projet de loi portant adaptation de la justice aux évolutions de la criminalité, tit. II, cap. 1, sec. 2 ("Dispositions relatives à la composition pénale et aux autres procédures alternatives aux poursuites”) (propone un nuevo texto para el art. 41-2.1 del Código Procesal Penal de Francia), disponible en http://www.assemblee-nat.fr/12/projets/p10784.asp (última visita del 25 de noviembre de 2003) (en los archivos de Harvard International Law Journal). Nota de actualización: esta propuesta de la "ley Perben" fue finalmente adoptada y la composition puede ahora aplicarse a todos los delitos de hasta cinco años de prisión.

${ }^{303}$ El mecanismo propuesto por la "ley Perben", ver supra nota 296, es más parecido al plea bargain estadounidense porque incluye negociaciones entre la fiscalía y la defensa con respecto a la pena, a cambio de una admisión de culpabilidad dentro del procedimiento formal, y en donde el tribunal tiene un papel limitado en las negociaciones. Ver Dominique Perben, Projet de loi portant adaptation de la justice aux évolutions de la criminalité, cap. IV, sec. 1, art. 61, sec. VIII ("De la comparution sur reconnaissance préalable de culpabilité”), disponible en http://www.assemblee-nat.fr/12/projets/p10784.asp (última visita del 25 de noviembre de 2003) (en los archivos de Harvard International Law Journal). 
la aplicación de la composition directamente evita estos procedimientos ${ }^{304}$. Segundo, la aplicación del plea bargaining estadounidense significa que el imputado es considerado legalmente culpable y luego castigado, en tanto que la aplicación de la composition no tiene el efecto legal de una sentencia de culpabilidad. Si el imputado cumple con las condiciones del acuerdo, entonces el caso es sobreseído ${ }^{305}$. Tercero, en el plea bargaining se considera que el fiscal está en iguales condiciones de negociación con la defensa. En la composition, por el contrario, el fiscal no negocia con un igual, sino que se asemeja más a un oficial de control del proceso a prueba que ejerce control sobre una persona que ha violado la ley y que puede cometer nuevos delitos en el futuro. El imputado debe aceptar el ofrecimiento del fiscal y admitir su culpabilidad, no como una parte que con su consentimiento puede poner fin a la disputa, sino como parte de su propio proceso de neutralización, rehabilitación y reparación a la víctima ${ }^{306}$.

Con la composition los legisladores franceses no tradujeron el plea bargaining estadounidense desde una estructura procesal de sentido acusatoria hacia una inquisitiva, sino desde un sistema acusatorio hacia lo que podría llamarse el "modelo de la despenalización". En la segunda mitad del siglo $\mathrm{XX}$, tuvo lugar en varios países europeos un movimiento hacia la despenalización de los delitos más leves ${ }^{307}$. Este modelo de la despenalización considera que el sistema de justicia penal regular, con sus penas de encarcelamiento, es demasiado severo y, al mismo tiempo, poco efectivo para lidiar con la criminalidad más leve. Así es que en reemplazo de la prisionización se propusieron las multas, el trabajo comunitario y la reparación a la víctima, entre otros remedios. También se diseñaron varios sistemas

\footnotetext{
${ }^{304}$ Ver Merle y Vitu, op. cit., p. 396.

${ }^{305} \mathrm{CPP}$ art. 41-2 (2002) (Francia).

${ }^{306} \mathrm{La}$ admisión de culpabilidad del imputado tiene un carácter pedagógico. Ministére de la Justice, op. cit., p. 65.

${ }^{307}$ Para un análisis sobre el desarrollo de este modelo en Europa, ver Delmas-Marty, Mireille. Les grands systèmes de politique criminelle. Presses universitaires de France, 1992, pp. 15963, 278-93. En Estados Unidos han existido ciertas tendencias en la misma dirección. Por ejemplo, la introducción de los mecanismos de la diversion en los últimos años para los casos de drogas, violencia doméstica y juvenil, puede ser considerado parte de un desarrollo similar. Para un análisis sobre la expansión de la diversion en Estados Unidos en las últimas tres décadas, ver, por ejemplo, Miller, op. cit., en 76, pp. 663-65.
} 
De los trasplantes legales a las traducciones legales: la globalización del plea...

alternativos, como los tribunales administrativos, civiles y de mediación, para procesar los casos que tradicionalmente eran resueltos a través del proceso penal ${ }^{308}$.

El modelo de la despenalización no pretende abolir o reemplazar por completo el sistema de justicia penal y sus procedimientos. Sino que más bien intenta limitar su alcance y funcionar de manera complementaria con éste ${ }^{309}$. Este modelo no adopta ningún tipo de procedimiento específico. Puede funcionar confortablemente con procedimientos administrativos relativamente inquisitivos, con procedimientos civiles estructurados según el modelo acusatorio de la disputa o con programas de mediación. El modelo de la despenalización pretende apartar a los delitos menos graves del proceso penal formal y evitar el encarcelamiento, al tiempo que mantiene cierto control formal sobre estos casos, con lo cual estos objetivos pueden alcanzarse a través de procesos diversos.

La composition puede ser incluida en este modelo de la despenalización ${ }^{310}$, de modo que, aun cuando sea exitosa y ampliamente utilizada ${ }^{311}$, lo cierto es que es poco probable que vaya a transformar al proceso penal regular inquisitivo francés en el sentido del modelo de la disputa; por el contrario, es más probable que fortalezca el modelo de la despenalización en Francia. Primero, y como ya lo analizamos, la propia composition, incluso si estuviese inspirada en el plea bargaining, no asume el modelo de la disputa porque no considera al imputado como una parte igual que la fiscalía. En este sentido, la composition no parece tener un potencial efecto

${ }^{308}$ Ver, por ejemplo, Tulkens, op. cit., pp. 648-49.

${ }^{309}$ La profesora Delmas-Marty distingue entre la despenalización y la descriminalización. Mientras que la primera podría ser un recurso complementario al sistema de justicia penal, la segunda se presenta como una alternativa al mismo. Ver Delmas-Marty, op. cit., pp. 278-79.

${ }^{310} \mathrm{La}$ composición es parte del modelo de la despenalización porque pretende excluir ciertos casos del sistema de justicia penal regular manteniéndolos bajo un control menos riguroso. Sobre este doble objetivo de la composición, ver Conte y Maistre du Chambon, op. cit., en nota 294 , p. 209.

${ }^{311}$ Por el momento los datos empíricos muestran que la composition ha sido utilizada con moderación. Hay estadísticas oficiales sobre el uso de esta práctica sólo para el año 2001. Sobre 893.373 casos iniciados, la composition se aplicó sólo en 1511 (0,17\%). Ver Minister de la Justice, Annuaire Statistique de la Justice 2003, disponible en http://www.justice.gouv. fr/publicat/m-Activparquets.pdf (última visita del 25 de noviembre de 2003) (en los archivos de Harvard International Law Journal). 
acusatorio o "americanizante". Segundo, aun cuando lo tuviese, el propio hecho de que la composition no se aplica dentro del proceso penal regular también haría que tenga poco potencial para mover al modelo de la investigación oficial francés en aquella dirección.

La traducción del plea bargaining en Francia, entonces, no parece representar un desafío a su modelo predominante de la investigación oficial en el proceso penal, menos aún que el desafío planteado por la introducción del procedimiento abreviado en Argentina.

\section{Conclusión: ¿fragmentación en las jurisdicciones continentales europeas y latinoamericanas?}

En las últimas cuatro secciones he demostrado cómo, en años recientes, las jurisdicciones de Alemania, Italia, Argentina y Francia han traducido el plea bargaining estadounidense de distintas formas, y cómo estos mecanismos, y sus interacciones con las prácticas y los actores legales del sistema de justicia penal receptor, así como otros factores, han producido diferentes resultados en cada una de estas jurisdicciones.

En el caso de Alemania, los Absprachen trajeron el desarrollo de un nuevo sistema procesal penal -el modelo del juez-gerente basado en la cooperación - que actualmente coexiste y cuestiona al modelo tradicional alemán de la investigación oficial. En el caso de Italia, el patteggiamento, junto a otras reformas, introdujo el modelo de la disputa que hoy representa un serio cuestionamiento al modelo tradicionalmente predominante de la investigación oficial. En el caso de Argentina, el procedimiento abreviado ha introducido y reforzado elementos del modelo de la disputa en el procedimiento penal federal, aunque el modelo de la investigación oficial sigue siendo dominante, mucho más que en Italia. Por último, en el caso de Francia, la composition puede reforzar el modelo de la despenalización y reducir el rango de casos procesados a través del modelo de la investigación oficial. De todos modos, este último modelo sigue siendo altamente predominante en el procedimiento penal regular.

Este análisis demuestra que parecen haber ahora diferencias importantes entre estas jurisdicciones, lo cual es novedoso en el mundo con- 
De los trasplantes legales a las traducciones legales: la globalización del plea...

tinental europeo y latinoamericano que durante mucho tiempo ha sido una cultura legal relativamente homogénea. Si bien existían diferencias entre estas jurisdicciones y cuestionamientos a la cultura procesal inquisitiva en el interior de cada una de ellas, en las cuatro aquí examinadas el proceso penal todavía se concebía principalmente en base al modelo de la investigación oficial. Es precisamente respecto de esta concepción común profunda del proceso penal que estas cuatro jurisdicciones están comenzando a diferir.

Así, mientras que la influencia estadounidense en el mundo continental europeo y latinoamericano es innegable, lo cierto es que, al menos en sus procedimientos penales formales, no está produciendo una "americanización" o "acusatorialización" fuerte de aquellas jurisdicciones, sino más bien su fragmentación. Esta fragmentación se debe, en parte, al hecho de que los sistemas inquisitivos han "traducido" las influencias acusatorias estadounidenses de diferentes maneras. En sus interacciones con el proceso penal receptor, cada mecanismo traducido tiene la capacidad tanto de transformar como de ser transformado por el sistema inquisitivo. Como resultado, los procesos penales de la tradición continental europea y latinoamericana ya han comenzado un proceso de diferenciación.

Este fenómeno tiene importantes consecuencias para el debate sobre la tesis de la "americanización". Porque si bien da apoyo a la versión débil de la tesis, en cuanto que confirma las influencias acusatorias sobre los sistemas inquisitivos, también debería conducir a una revisión, y a un análisis más concreto y complejo, de la versión fuerte de la tesis. Tal como demuestra esta discusión, la influencia del sistema estadounidense sobre otros sistemas legales puede producir diferentes efectos en cada uno de ellos, dependiendo de las decisiones tomadas por los traductores legales, de cuánto poder han tenido para promover sus reformas, de cuánta resistencia han encontrado, etc. Además, este estudio demuestra que la "americanización" no es un juego a todo o nada.

En otras palabras, las prácticas del sistema legal receptor pueden moverse en dirección del sistema estadounidense en un determinado nivel del procedimiento, pero no en otro, como ocurre con el caso del sistema alemán, en donde es improbable que los Absprachen promuevan el modelo estadounidense de la disputa, pero pueden promover una concepción de 
la verdad más consensuada y relativa, como la que prevalece en el sistema estadounidense.

En mi argumento he señalado dos cuestiones adicionales que vale la pena reiterar aquí. Primero, he discutido algunos de los defectos que tiene la metáfora del trasplante legal como criterio para entender la circulación de instituciones legales entre sistemas legales, y he propuesto la metáfora de la traducción legal como un dispositivo heurístico alternativo para abordar estos fenómenos. Algunos podrán considerar que la discusión de las metáforas es un juego de palabras sin mucho valor sustantivo, pero esto sería un error. Las metáforas son importantes porque pensamos a través de ellas y porque resaltan diferentes aspectos de la realidad. El principal concepto que pretendo enfatizar a través de la metáfora de la traducción legal es que las prácticas e instituciones legales pueden ser transformadas al ser trasladadas entre los sistemas legales, tanto por decisiones de los reformadores (traductores) o por diferencias estructurales entre el sistema originario y el receptor (idiomas). Además, la institución legal traducida puede producir una sucesión de cambios -incluso inesperados como el caso del Absprache alemán- en el sistema legal receptor. Si se tiene en cuenta que gran parte de la doctrina y de los productores de políticas públicas han pasado por alto estas transformaciones, entonces la metáfora de la traducción resulta útil para ponerlas de resalto.

Segundo, he mostrado que los sistemas acusatorio e inquisitivo pueden ser analizados no sólo como dos formas distintas de distribuir el poder y las responsabilidades entre los principales actores del proceso penal, sino también como dos culturas procesales distintas - dos concepciones diferentes de cómo deben juzgarse y perseguirse los casos penales-. Aun cuando estas culturas procesales no sean enteramente homogéneas, hay ciertas concepciones del proceso penal que claramente han prevalecido en los Estados Unidos y en las cuatro jurisdicciones continentales europeas y latinoamericanas aquí examinadas. He propuesto un nuevo marco teórico para analizar estas culturas procesales predominantes, y lo he utilizado para explicar algunas de las transformaciones que el plea bargaining ha sufrido al ser traducido en Alemania, Italia, Argentina y Francia.

Esta conceptualización de los sistemas acusatorio e inquisitivo también nos ha brindado un claro eje de referencia para valorar si estas cuatro juris- 
De los trasplantes legales a las traducciones legales: la globalización del plea...

dicciones se están moviendo, o se han movido, en la dirección del sistema estadounidense.

La conceptualización de los sistemas acusatorio e inquisitivo como culturas procesales también es importante por otros motivos. El debate sobre la "americanización" del derecho es, en cierta medida, un debate sobre culturas legales. En otros términos, es un debate acerca de cómo se entiende, se piensa y se practica el derecho en diferentes jurisdicciones, y cómo ciertas concepciones legales que prevalecen en los Estados Unidos pueden llegar a imponerse en otros lados. Por lo tanto, una conceptualización teórica de los sistemas acusatorio e inquisitivo como la que se ofrece en este artículo es necesaria para participar plenamente en este debate.

\section{Bibliografía}

Abel, R. L., "Law as Lag: Inertia as a Social Theory of Law", Michigan Law Review, vol. 80, 1982

Abrams, N., "Prosecution: Prosecutorial Discretion", en Kadish, Sanford H. Encyclopedia of Crime and Justice (Volume 3), The Free Press Macmilan Publisher, New York, 1983

Ajani, G., "By Chance and Prestige: Legal Transplants in Russia and Eastern Europe", American Journal of Comparative Law vol. 43, p. 93 (1995)

Alpert Gladstone, J., "Why Patenting Information Technology and Business Methods is Not Sound Policy: Lessons from History and Prophecies for the Future", Hamline Law Review, vol. 25, p. 217, 229 (2002).

Alschuler, A. W., "Plea Bargaining and Its History", Law and Society Review, vol. 13, 1979

Alschuler, A. W., "Implementing the Criminal Defendant's Right to Trial: Alternatives to the Plea Bargaining System", University of Chicago Law Review, vol. 50, 1983

Amann, D.M., "Harmonic Convergence? Constitutional Criminal Procedure in an International Context", Indiana Law Journal vol. 75, 2000 
Amodio, E. \& Selvaggi, E., "An Accusatorial System in a Civil Law Country: The 1988 Italian Code of Criminal Procedure", Temple Law Review, vol. 62, 1989.

Amodio, E., "Il Modello Accusatorio Statunitense e il Nuovo Processo Penale Italiano: Miti e Realtà della Giustizia Americana”, en Amodio, Ennio, and M. Cherif Bassiouni (eds.), Il processo penale negli Stati Uniti d'America. Giuffrè, 1988.

Arenella, P., "Rethinking the Functions of Criminal Procedure: The Warren and Burger Courts' Competing Ideologies", Georgetown Law Journal, vol. 72, p. 183 (1983).

Arenella, P., "Reforming the Federal Grand Jury and the State Preliminary Hearing to Prevent Conviction without Adjudication", Michigan Law Review, vol. 78, 1980.

Bailyn, B., The ideological origins of the American Revolution, Harvard University Press, 1992.

Barra Cousino, C. R., "Adversarial vs. Inquisitorial Systems: The Rule of Law and Prospects for Criminal Procedure Reform in Chile", Southwestern Journal of Law and Trade in the Americas., 1998, vol. 5.

Bartlett, R., Trial by Fire and Water: The Medieval Judicial Process, Oxford, Clarendon Press, 1986.

Bassnett, S., Translation studies, Routledge, 2013.

Berkowitz, D., et al. "Economic Development, Legality, and the Transplant Effect" (Center for International Development at Harvard University, Working Paper No. 39, 2000, disponible en http:// www.cid.harvard. edu/cidwp/039.htm (último acceso el 25 de noviembre de 2003) (en los archivos de Harvard International Law Journal);

Bertoni, E.A., Libertad de expresión en el Estado de Derecho, Buenos Aires, Editores del Puerto, 2000, p. 72-82.

Blankenburg, E., "Changes in Political Regimes and Continuity of the Rule of Law in Germany", en Jacob, H. et al. Courts, Law and Politics in Comparative Perspective, Michigan, Yale University Press, 1996, p. 249, 308.

Bourdieu, P., Language and symbolic power, Harvard University Press, 1991. Bourdieu, P., "The Social Conditions of the International Circulation of Ideas", en Shusterman, Richard, ed. Bourdieu: A critical reader, 1999. 
De los trasplantes legales a las traducciones legales: la globalización del plea...

Bourdieu, P., Raisons pratiques. Sur la théorie de l'action. Le seuil, 2016.

Bovino, A., Temas de derecho procesal penal guatemalteco. No. 343.1

(728.1), Fundación Myrna Mack, 1996.

Bradley, C. M., "United States", Criminal Procedure: a Worldwide Study, Carolina Academic Press, 1999.

Bradley, C. M., "The convergence of the continental and the common law model of criminal procedure", Criminal Law Forum, Vol. 7, No. 2, Kluwer Academic Publishers, 1996.

Buscaglia, E. y Rafliff, W., Law and Economics in Developing Countries, Hoover Institution Press, 2000.

Cafferata Nores, J. I., Cuestiones actuales sobre el Proceso Penal, Editores del Puerto, 2a ed1, 1998.

Calabresi, S. G., "The Tradition of the Written Constitution: A Comment on Professor Lessig's Theory of Translation", Fordham Law Review, vol. 65, 1997.

Cedras, J., "L'hypothèse de l'américanisation du droit pénal français, en Archives de Philosophie du Droit, vol. 45, 2001.

Champy, G., "Inquisitoire-Accusatoire devant les juridictions pénales internationales", International Law Review of Penal Law, vol. 68, 1997, p. 149.

Chayes, A., "The Role of the Judge in Public Law Litigation", Harvard Law Review, vol. 89, 1976

Chodosh, H. E., "Reforming Judicial Reform Inspired by U.S. Models", DePaul Law Review., vol. 52, 2002.

Cordero, F., Procedura Penale, Giuffré, 1993.

Cedras, J., "L’hypothèse de l'américanisation du droit pénal français", en Archives de Philosophie du Droit, vol. 45, 2001.

Combs, N. A., "Copping a plea to genocide: the plea bargaining of international crimes", University of Pennsylvania Law Review, 151, 2002.

Damaška, M., "Adversary System", en Kadish, S.H. (ed.), Encyclopedia of Crime and Justice, Nueva York, Free Press, 1983.

Damaška, M., "Models of criminal procedure", Zbornik PFZ, 51, 2001.

Damaška, M. R., The faces of justice and state authority: a comparative approach to the legal process. Yale University Press, 1986. 
Damaška, M. R., “The Uncertain Fate of Evidentiary Transplants: Anglo-American and Continental Experiences", American Journal of Comparative Law, vol. 45, 1997, p. 839.

Damaška, M, R., Evidence law adrift, Yale University Press, 1997.

Damaška, M. R., "Aspectos globales de la reforma del proceso penal", Reformas a la Justicia penal en las Américas. www. dplf. org/Fundación para el debido proceso legal, 2000.

Damaška, M. R., "Of hearsay and its analogues", Minnesota Law Review 76, 1992, p. 425, 449-52.

Davis, K. C., Discretionary justice: A preliminary inquiry, LSU Press, 1969.

Davison, J., "America's Impact on Constitutional Change in Eastern Europe", Albany Law Review, 55, 793, 1992.

Deal, D., "Der strafprozessuale Vergleich", Strafverteidiger vol.2, 1982

Delazay, Y. y Garth B.G., Dealing in Virtue: International Commercial Arbitration and the Construction of a Transnational Legal Order, Chicago, Chicago University Press, 1996.

Delmas-Marty, M., "Rapport sur la mise en état des affaires pénales", Commission Justice pénale et droits de l'Homme, 1991.

Delmas-Marty, M., Les grands systèmes de politique criminelle, Presses universitaires de France, 1992.

Dervieux, V., “The french system”, en Delmas-Marty, Mireille, and John R. Spencer (eds.) European criminal procedures, Vol. 25, Cambridge University Press, 2002.

Dorf, M. C., "Recipe for Trouble: Some Thoughts on Meaning, Translation and Normative Theory", Fordham Law Review, vol. 65, 1997.

Doucet, M. and Jacques, V., La réception des systèmes juridiques: implantation et destin, Bruyant, 1994.

Dryden, J., “On Translation”, en Jakobson, R., Schulte, R., \& Biguenet, J. (eds.), Theories of translation: An anthology of essays from Dryden to Derrida.

Dubber, M. D., "The German Jury and the Metaphysical Volk: From Romantic Idealism to Nazi Ideology", American Journal of Comparative Law, 43, 1995. 
De los trasplantes legales a las traducciones legales: la globalización del plea...

Dubber, M. D., "American Plea Bargains, German Lay Judges, and the Crisis of Criminal Procedure”, Stanford Law Review, vol. 49, 1997.

Easterbrook, F. H., "Criminal Procedure as a Market System", Journal of Legal Studies, vol. 12, 1983.

Easterbrook, Frank H. "Plea Bargaining as Compromise” Yale Law Journal, vol. 101, 1991.

Eisenberg, T. \& Yeazell, S. C., "The Ordinary and the Extraordinary in Institutional Litigation", Harvard Law Review., vol. 93, 1980.

Esmein, A., Histoire de la procédure criminelle en France: et spécialement de la procédure inquisitoire depuis le XIIIe siècle jusqu'a nos jours, L. Larose et Forcel, 1882.

Ewald, W., "The American Revolution and the Evolution of Law", American Journal of Comparative Law, vol. 42, 1994.

Ewald, W., "Comparative Jurisprudence (II): The Logic of Legal Transplants", American Journal of Comparative Law vol. 43, 1995.

Ferrua, P., "La Giustizia Negoziata nella Crisi della Funzione Cognitiva del Processo Penale", Studi sul Processo Penale, vol. 3, 1997.

Fisher, G., "Plea Bargaining's Triumph", Yale Law Review, vol. 109, 2000.

Fiss, O. M., "Foreword: The Forms of Justice, Harvard Law Review, vol. 93, 1979.

Fournier, A., Code de Procédure Criminelle De L'État de New York, 1893.

Frankel, M. E., “The search for truth: An umpireal view”, University of Pennsylvania Law Review, 123.5 1975, p. 1031-1059.

Frase, R. S., "The Decision to File Federal Criminal Charges: A Quantitative Study of Prosecutorial Discretion", University of Chicago Law Review, vol. 47, 1980, p. 246.

Frase, R. S., "Comparative Criminal Justice as a Guide to American Law Reform: How Do the French Do It, How Can We Find Out, and Why Should We Care?”, California Law Review, vol. 78, 1990, p. 539.

Frase, R. S.,, and Thomas Weigend. "German criminal justice as a guide to American law reform: Similar problems, better solutions", Boston College International and Comparative Law Review, vol. 18, 1995.

Friedman, L. M., "Plea Bargaining in Historical Perspective", Law and Society Review, vol. 13, 1979. 
Friedman, L. M., "Erewhon: The Coming Global Legal Order” Stanford Journal of International Law, vol. 37, 2001.

Garapon, A., "French Legal Culture and the Shock of 'Globalization", Sociological and Legal Studies, vol. 4, 1995.

Garraud, R. and Garraud, P., Traité théorique et pratique d'instruction criminelle et de procédure pénale, Vol. 1, Sirey, 1907.

Geertz, C., The interpretation of cultures, Vol. 5019, Basic books, 1973.

Geertz, C., Local knowledge: further essays in interpretive anthropology, New York 1983.

Gleadow, C., History of trial by jury in the Spanish legal system, No. 6, Edwin Mellen Pr, 2000, p. 245-85.

Gidi, A., "Class Actions in Brazil--A Model for Civil Law Countries", American Journal of Comparative Law vol. 51, 2003.

Gildin, G. S., "Trial by Jury in the New Russia: A Travelogue” Dick Journal of International Law, vol. 15, 1996.

Glenn Patrick, H., Legal Traditions of the World. Oxford University Press, 2000.

Goldstein, A. S., "Reflections on Two Models: Inquisitorial Themes in American Criminal Procedure”, Stanford Law Review, vol. 26, 1974.

Goldstein, A. S., y Marcus, M., "The myth of judicial supervision in three" inquisitorial systems: France, Italy, and Germany", The Yale Law Journal, 87.2, 1977, p. 240-283.

Guarnieri, C., "Prosecution in Two Civil Law Countries: France and Italy", en Nelken, David. Comparing legal cultures, Routledge, 1997.

Griffiths, J., "Ideology in Criminal Procedure, or a Third 'Model' of the Criminal Process", Yale Law Journal, vol. 79, 1970, p. 359.

Grande, E., "Italian Criminal Justice: Borrowing and Resistance", American Journal of Comparative Law vol. 48, 2000, p. 227.

Harcourt, B. E., Illusion of order: The false promise of broken windows policing, Harvard University Press, 2009.

Hart, H.L.A., The Concept of Law, Oxford, Oxford University Press, 2a ed.

Hélie, F., Traité de l'instruction criminelle ou Théorie du code d'instruction criminelle, vol. 5, 1853. 
De los trasplantes legales a las traducciones legales: la globalización del plea...

Herrmann, J., "Bargaining Justice--A Bargain for German Criminal Justice?", University of Pittsburgh Law Review, vol. 53.

Heymann, P. B., "Should Latin American Prosecutors be Independent of the Executive in Prosecuting Government Abuses?", University of Miami Inter-american Law Review, vol. 26, 1995.

Henkin, L. y Rosenthal, A.J., Constitutionalism and Rights: The Influence of the United States Constitution Abroad, Columbia, Columbia University Press, 1990.

Herrmann, J., "Various Models of Criminal Proceedings", South African Journal of Criminal Law and Criminology, vol. 2, 1978.

Herrmann, J., "Bargaining Justice--A Bargain for German Criminal Justice?", University of Pittsburgh Law Review, vol. 53, 1992.

Hett, B. C., Death in Tiergarten and Other Stories: Murder and Criminal Justice in Berlin, 1891-1933.

Holden, B., (ed.) The ethical dimensions of global change, Springer, 1996.

Janosik, R.J., (ed.) Encyclopedia of the American Judicial, Charles Scribners Sons, 1987.

Jenson, J. and Sousa Santos, B., (eds.), Globalizing institutions: Case studies in regulation and innovation, Routledge, 2000.

Kagan, R., Adversarial legalism: The American way of law, Harvard University Press, 2009 (original dice 2001, ver nota 50 y 111).

Kahn-Freund, O., "On uses and misuses of comparative law”, Modern Law Review, 37, 1974.

Kahn, P. W., The cultural study of law: Reconstructing legal scholarship, University of Chicago Press, 2000.

Kahn-Freund, O., “On Uses and Misuses of Comparative Law”, Selected Writings, 1978.

Kenan, L., "Translation as a Catalyst for Social Change in China", en Tymoczko, Maria, y Edwin Gentzler (eds.) Translation and power, Univ of Massachusetts Press, 2002.

Kennedy, D., “Three Legal Globalizations”, Inédito, 2001.

Krug, P., "Prosecutorial Discretion and its Limits", American Journal of Comparative Law, vol. 50, 2002, p. 643. 
Kühne, H.H., "Germany” en Van den Wyngaert, Christine, et al., (eds.) Criminal procedure systems in the European Community, Butterworths, 1999.

LaFave, W. R., "The Prosecutor's Discretion in the United States", American Journal of Comparative Law vol. 18, 1970.

Langbein, J. H., Comparative criminal procedure: Germany, St. Paul, MN.: West Publishing Company, 1977.

Langbein, J. H., Torture and the law of proof: Europe and England in the Ancien Régime, University of Chicago Press, 1977.

Langbein, J. H., “Torture and Plea Bargaining”, University of Chicago Law Review, vol. 46, 1978.

Langbein, J. H. \&. Weinreb, L. L., "Continental Criminal Procedure: Myth and Reality", Yale Law Journal, vol. 87, 1978.

Langbein, J. H., "Land Without Plea Bargaining: How the Germans Do It", Michigan Law Review, vol, 78, 1979.

Langbein, J. H., "Understanding the Short History of Plea Bargaining”, Law and Society Review, vol. 13, 1979.

Langbein, John H., "Mixed Court and Jury Court: Could the Continental Alternative Fill the American Need?", American Bar Foundation Research Journal 6.1, 1981, 195-219.

Langbein, John H., "The Influence of Comparative Procedure in the United States", American Journal of Comparative Law, vol. 43, 1995.

Langbein, John H., "The Influence of the German Emigrés on American Law: The Curious Case of Civil and Criminal Procedure", en Lutter, Marcus, Stiefel, Ernst y Hoeflich, Michael H (eds.) Der Einfluss deutscher Emigranten auf die Rechtsentwicklung in den USA und in Deutschland: Vorträge und Referate des Bonner Symposions im September 1991, Mohr Siebeck, 1993.

Langbein, J. H., “The Influence of Comparative Procedure in the United States", American Journal of Comparative Law, vol. 43, 1995.

Langbein, J. H., and Simpson, AW B., The origins of adversary criminal trial. Oxford University Press, 2003.

Lechner, F. J. and Boli, J., (eds.) The globalization reader, John Wiley \& Sons, 2000. 
De los trasplantes legales a las traducciones legales: la globalización del plea...

Legrand, P., "European Legal Systems Are Not Converging”, International and Comparative Law Quaterly, vol. 45, 1996.

Lessig, L., "Fidelity and Constraint", Fordham Law Review, vol. 65, 1997.

Lessig, L., "Fidelity and Constraint", Fordham Law Review, vol. 65, 1997.

Lessig, L.,"Fidelity in Translation”, Texas Law Review, vol. 71, 1993.

Lessig, L., "The Puzzling Persistence of Bellbottom Theory: What a Constitutional Theory Should Be", Georgetown Law Journal, vol. 85, 1997.

Lessig, L., “Translating Federalism: United States v. Lopez”, Supreme Court Review, vol. 1995

Lessig, L., "Understanding Changed Readings: Fidelity and Theory", Stanford Law Review, vol. 47, 1995.

Levinson, ., “Translation: Who Needs It?", Georgetown Law Review, vol. 85, 1997.

López-Medina, D., Comparative Jurisprudence: Reception and Misreading of Transnational Legal Theory in Latin America, 2001 (tesis doctoral no publicada, Harvard University en el archivo de Harvard Law School Library).

Luna, E. G., "The Models of Criminal Procedure”, Buffalo Criminal Law Review, vol. 2, 1999, p. 389.

Maier, J., "El proyecto de Código Procesal Penal de la Nación: presentación de Julio B. Maier, Exposición de motivos, texto completo del proyecto,", Cuadernos de la Revista Doctrina Penal, Series No.1, 1987.

Maier, J. B. J., "Mecanismos de Simplificación del Procedimiento Penal", Cuadernos de doctrina y jurisprudencia penal, 1998.

Maier, J. B. J y Bovino, A., (eds.) El procedimiento abreviado, Buenos Aires, Editores del Puerto, 2001.

Maier, J. B. J. \& Langer, M., “Acusación y Sentencia”, Nueva Doctrina Penal, 1996/B.

May, R. \& Wierda, M.,"Trends in International Criminal Evidence: Nuremberg, Tokyo, The Hague, and Arusha", Columbia Journal of Transnational Law, vol. 37, 1999. 
Markesinis, B., (ed.) The Gradual convergence: foreign ideas, foreign influences, and English law on the eve of the 21st century, Clarendon Press, 1994.

Mattei, U., "A Theory of Imperial Law: A Study on U.S. Hegemony and the Latin Resistance", Indiana Journal of Global Legal Studies, vol. 10, 2003, p. 383.

Mattei, U., "Why the Wind Changed: Intellectual Leadership in Western Law", American Journal of Comparative Law, vol. 42, 1994, p. 195.

Mattei, U., "Efficiency in Legal Transplants: An Essay in Comparative Law and Economics", International Review of Law and Economics, vol. 14, 1994.

McGrew, A. G. and Held, D., (eds.) The global transformations reader: an introduction to the globalization debate, Polity Press, 2000.

McGrew, A. G., and Held, D., (eds.) The global transformations reader: an introduction to the globalization debate, Polity Press, 2000.

Meares, T. L., "Rewards for Good Behavior: Influencing Prosecutorial Discretion and Conduct with Financial Incentives", Fordham Law Review, vol. 64, 1995

Merryman, J. H., “The Civil Law Tradition: An Introduction to the Legal Systems of." (1985).

Merle, R. and Vitu, A., Traité de droit criminel, 5éme édition, Paris, 2001.

Miller, J. M., "A Typology of Legal Transplants: Using Sociology, Legal History and the Argentine Example to Explain the Transplant Process", en American Journal of Comparative Law vol. 51

Miller, F.., et al. Criminal Justice Administration: Cases and Materials, Foundation Press, 2007.

Misner, R.L., "Recasting Prosecutorial Discretion", Journal of Criminal Law and Criminology, vol. 86, 1996.

Mistelis, L. A., "Regulatory Aspects: Globalization, Harmonization, Legal Transplants and Law Reform--Some Fundamental Observations", en International Law, vol. 34 (2000), p. 1055.

Moskovitz, M., "Perspective: The O.J. Inquisition: A United States Encounter with Continental Criminal Justice", Vanderbilt Journal of Transnational Law, vol. 28, 1995. 
De los trasplantes legales a las traducciones legales: la globalización del plea...

Mundis, D. A., "From 'Common Law' Towards 'Civil Law': The Evolution of the ICTY Rules of Procedure and Evidence", Leiden Journal of International Law, vol. 14, 2001.

Nota Estudiantil, "The Protectionist Bar against Foreign Lawyers in Japan, China and Korea: Domestic Control in the Face of Internationalization", Columbia Journal of Asian Law, vol. 16, 389, 2003.

Orland, L., "A Russian Legal Revolution: The 2002 Criminal Procedure Code", Conneticut Journal of International Law, vol. 18, 2002.

Ostrow, E. J., “The Case for Preplea Disclosure”, Yale Law Journal, vol. 90, 1981.

Ortwein II, B. M., "The Swedish Legal System: An Introduction” en Indiana International and Comparative Law Review, vol. 13, 2003.

Packer, H.L., The Limits of the Criminal Sanction, Stanford, Stanford University Press, 1968.

Pizzi, W. T., "Understanding Prosecutorial Discretion in the United States: The Limits of Comparative Criminal Procedure as an Instrument of Reform", Ohio State Law Journal, vol. 54, 1993.

Pizzi, W. T. Trials without truth: why our system of criminal trials has become an expensive failure and what we need to do to rebuild it, NYU Press, 2000.

Pizzi, W. T. \& Marafioti, L., “The New Italian Code of Criminal Procedure: The Difficulties of Building an Adversarial Trial System on a Civil Law Foundation", Yale Journal of International Law, vol. 17, 1992.

Plotkin, S. R., “The Jury Trial in Russia” Tulane Journal of International and Comparative Law, vol. 2, 1994, p. 1.

Pradel, J., Droit pénal comparé, Dalloz, 2002.

Pradel, J., "Inquisitoire-Accusatoire: une redoutable complexité, International Review of Penal Law, vol. 68, 1997.

Provine, D. M., "Courts in the Political Process in France", en Jacob, H., Blankenburg, E., Kritzer, H. M., Provine, D. M., \& Sanders, J. Courts, law, and politics in comparative perspective, Yale University Press, 1996.

Ramírez, L. R., García \& Urbina, M. A. Guatemala en Ambos, K., Maier, J. et al. Las reformas procesales penales en América Latina, AD-HOC, 2000 . 
Raustiala, K., "The Architecture of International Cooperation: Transgovernmental Networks and the Future of International Law", Virginia Journal of International Law, 2002.

Reiss, A. J., "Public prosecutors and criminal prosecution in the United States of America", Jurid. Rev., 1975.

Rheinstein, M., "Introduction" a Rheinstein, Max (ed.) Max Weber on Law in Economy and Society. Harvard University Press, 1954.

Rosett, A., "Discretion, Severity and Legality in Criminal Justice", Southern California Law Review, vol. 46, 1972.

Roxin, C. and Schünemann, B., Strafverfahrensrecht, München, 1998, 25.

Rubenstein, W. B., "A Transactional Model of Adjudication", Georgetown Law Review, vol. 89, 2001.

Salas, D.,. "La justice entre les deux corps de la démocratie", en Salas, D., (ed.), La justice, une révolution démocratique, Desclée de Brouwer, 2001.

Sassen, S., Globbalization and Its Discontents. Essays on the new mobility of people and money, New York, 1998.

Saussure, F. de, Course in general linguistics, New York: Philosophical Library , 1959.

Schauer, F., "The Politics and Incentives of Legal Transplantation", en Nye, Joseph S. Jr. \& Donahue, John D. (eds.) Governance in a Globalizing World, Washington, Brookings Institution Press, 2000.

Schioppa, P. A., "I Philosophes e la Giuria Penale." I-II Nuova Rivista Storica 107, 1986.

Schioppa, P. A., (Ed.), The Trial Jury in England, France, Germany, 17001900, Berlín, Duncker und Humblot, 1987.

Schlesinger, R. B., "Comparative Criminal Procedure: A Plea for Utilizing Foreign Experience”, Buffalo Law Review, vol. 26, 1977.

Schulhofer, S. J., "Is Plea Bargaining Inevitable?" Harvard Law Review, vol. 97, 1983.

Schulhofer, S. J., "Plea Bargaining as Disaster", Yale Law Journal, vol. 101, 1991.

Schünemann, B., Absprachen im Strafverfahren?: Grundlagen, Gegenstände und Grenzen: Gutachten B für den 58. Deutschen Juristentag, CH Beck, 1990. 
De los trasplantes legales a las traducciones legales: la globalización del plea...

Schünemann, B., “Die Absprachen im Strafverfahren”, en Hanack, ErnstWalter, et al., eds. Festschrift für Peter Riess zum 70. Geburtstag am 4. Juni 2002, Walter de Gruyter, 2011.

Scott, R. E. \& Stuntz, W. J., "Plea Bargaining as Contract", en Yale Law Journal, vol. 101, 1992.

Spencer, J.R.S. "French and English Criminal Procedure", en Markesinis, Basil, ed. The Gradual convergence: foreign ideas, foreign influences, and English law on the eve of the 21st century. Clarendon Press, 1994.

Steiner, G., After Babel: Aspects of Language and Translation, Oxford, Oxford University Press, 1998.

Stewart, M., "Global Trajectories of Tax Reform: The Discourse of Tax Reform in Developing and Transition Countries", Harvard International Law Review, vol. 44, p. 139, 151 (2003).

Stith, K. \&. Cabranes, J. A., "Judging Under the Federal Sentencing Guidelines", Northwestern University Law Review., vol. 91, 1997.

Stribopoulos, J., "Lessons from the Pupil: A Canadian Solution to the American Exclusionary Rule Debate", Boston College International and Comparative Law Review, vol. 22, 1999, p. 77.

Swenson, T., “The German 'Plea Bargaining' Debate”, Pace International Law Review, 1995.

Thaman, S. C., "The Resurrection of Trial by Jury in Russia", Stanford Journal of International Law, vol. 31, 1995.

Thaman, S. C., "Spain Returns to Trial by Jury", Hastings International and Comparative Law Review, vol. 21, 1998, p. 241.

Thaman, S. C., "Europe's New Jury Systems: The Cases of Spain and Russia", Law and Contemporary Problems, vol. 62, 1999.

Teubner, G., "The Two Faces of Janus: Rethinking Legal Pluralism”, Cardozo Law Review, vol 13, 1992.

Teubner, Gunter "Legal Irritants: Good Faith in British Law or How Unifying Law Ends Up in New Divergences", Modern Law Review, vol. 61, 1998. 
Tochilovsky, V., "Rules of Procedure for the International Criminal Court: Problems to Address in Light of the Experience of the Ad Hoc Tribunals", Netherland International Law Review, vol. 46, 1999.

Torres, G., "Translation and Stories", en Harvard Law Review, vol. 115, 2002.

Tung, F., "Passports, Private Choice, and Private Interests: Regulatory Competition and Cooperation in Corporate, Securities, and Bankruptcy Law", Chicago Journal of International Law, vol. 3, p. 369 n.43, 2002.

Tulkens, F., "Negotiated justice", European criminal procedures, 2002.

Van Kessel, G., "European perspectives on the accused as a source of testimonial evidence", West Virginia Law Review, 100, 1997.

Van Kessel, G., "Adversary Excesses in the American Criminal Trial", Notre Dame Law Review, vol. 67, 1992.

Venuti, L., The translator's invisibility: a history of translation, London and New York: Routledge, 1995.

Von Nessen, P., “The Americanization of Australian Corporate Law”, en Syracuse Journal of International Law and Commerce, vol. 26, 1999.

Vorenberg, J., "Decent Restraint of Prosecutorial Power", Harvard Law Review, vol. 94, 1981.

Watson, A., Society And Legal Change, 2Nd Ed, Temple University Press, 1977.

Watson, A., Evolution of Law, Johns Hopkins University Press, 1985.

Watson, A., Legal Transplants: an Approach to Comparative Law, Londres y Atenas, Georgia University Press, 2a ed., 1993.

Watson, A., "Aspects of Reception of Law", American Journal of Comparative Law, vol. 44, 1995.

Weigend, T., "Abgesprochene Gerechtigkeit-- Effizienz durch Kooperation im Strafverfarhern?", Juristenzeitung, vol. 45, 1990.

Weigend, T., "Eine Prozessordnung für abgesprochene Urteile?", Neue Zeitschrift für Strafrecht [NSTZ] 57, 1999.

Weigend, T., "Prosecution: Comparative Aspects", en Dressler, Joshua (ed.) Encyclopedia of Crime \& Justice 1235 (2001), McMillan, 2002.

Weiner, J. B., "Responding to the Global Warming Problem: Something Borrowed for Something Blue: Legal Transplants and the Evolution 
De los trasplantes legales a las traducciones legales: la globalización del plea...

of Global Environmental Law", Ecology Law Quaterly, vol. 27, 2001, p. 1295.

Weinreb, L. L., Denial of Justice: Criminal Process in the United States, New York: Free Press, 1977.

White, J. B., Justice as translation: An essay in cultural and legal criticism, University of Chicago Press, 1994.

Wiegand, W., "Americanization of Law: Reception or Convergence?", en Friedman, L.M. y Scheiber H.N. (eds.) Legal Culture and The Legal Profession. Boulder, West View, 1996, p. 137.

Wiegand, W., “The Reception of American Law in Europe”, American Journal of Comparative Law, vol. 39, 1991, p. 229.

Zamora, S., "The Americanization of Mexican Law: Non-Trade Issues in the North American Free Trade Agreement", Law and Policy in International Bussiness, vol. 24, 1993, p. 391.

Zasloff, J., “The Tyranny of Madison”, UCLA Law Review, vol. 44, 1997, p. 795.

Zweigert, K. and Kötz, H., Introduction to comparative law, Oxford University Press, 3ª ed. 1998. 